\author{
UNIVERSITY OF CALIFORNIA \\ COLLEGE OF AGRICULTURE \\ AGRICULTURAL EXPERIMENT STATION \\ BERKELEY, CALIFORNIA
}

\title{
STOCK-POISONING PLANTS OF CALIFORNIA
}

ARTHUR W. SAMPSON AND HARRY E. MALMSTEN

\section{BULLETIN 593}

AUGUST, 1935 
Digitized by the Internet Archive in 2012 with funding from

University of California, Davis Libraries 


\section{CONTENTS}

Introduction . . . . . . . . . . . . . . . . . 3

Conditions of poisoning . . . . . . . . . . . . . . . . . . . . . . 4

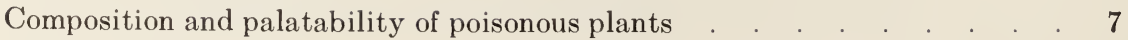

Plant poisons . . . . . . . . . . . . . . . . . . 10

Poisonous plants of primary importance . . . . . . . . . . . . . . . 11

Larkspurs . . . . . . . . . . . . . . . . . 12

Monkshood . . . . . . . . . . . . . . . . . . . 17

St. Johnswort . . . . . . . . . . . . . . . . . 18

Death camas . . . . . . . . . . . . . . . . . 21

Lupines . . . . . . . . . . . . . . . . . . . 24

Water hemlock . . . . . . . . . . . . . . 28

Poison hemlock . . . . . . . . . . . . . . . . . . . 32

Loco weeds . . . . . . . . . . . . . . . . . . . 34

Milkweeds . . . . . . . . . . . . . . . . . . 37

Laurels, azaleas, and other heaths . . . . . . . . . . . . . . 41

Wild tobaccos . . . . . . . . . . . . . . . . . . . . 45

Bracken fern . . . . . . . . . . . . . . . . . . 49

Poisonous plants of secondary importance _ . . . . . . . . . . . . . . 51

Arrow-grass . . . . . . . . . . . . . . . . . . . . 51

The sorghums . . . . . . . . . . . . . . . . . . . 54

False hellebores . . . . . . . . . . . . . . . . . . . . 55

Black greasewood . . . . . . . . . . . . . . . . . . . 56

Mexican tea, wormseed, and Jerusalem tea _. . . . . . . . . . . 58

Fitweed . . . . . . . . . . . . . . . . . 58

Western chokecherry . . . . . . . . . . . . . . . . . 60

Thorn apples . . . . . . . . . . . . . . . . . . . . . . . . . 62

Black nightshade . . . . . . . . . . . . . . . . . . 63

Cocklebur . . . . . . . . . . . . . . . . . . . 64

Western sneezeweed . . . . . . . . . . . . . . . . . 65

Spring rabbit-brush . . . . . . . . . . . . . . . . . . 67

Horsetails or scouring rushes . . . . . . . . . . . . . . . 68

Poisonous mushrooms . . . . . . . . . . . . . . . . . . . . . 69

Ergot . . . . . . . . . . . . . . . . . . . 71

Poisonous plants of minor or local importance . . . . . . . . . . . 71

Poisonous grasses . . . . . . . . . . . . . . . . . . 72

Summary of facts regarding the more common poisonous species . . . . 78

Acknowledgments . . . . . . . . . . . . . . . . . . . 82

Bibliography . . . . . . . . . . . . . . . . . . . . . . 83 



\title{
STOCK-POISONING PLANTS OF CALIFORNIA ${ }^{1}$
}

\author{
ARTHUR W. SAMPSON ${ }^{2}$ AND HARRY E. MALMSTEN ${ }^{3}$
}

\section{INTRODUCTION}

PoISONOUS PLANTS are the cause of heavy losses annually among all kinds of domestic animals maintained on range or pasture. Perhaps nothing causes more vexation and discouragement than losses aseribed to this source. Stockmen have long recognized in general the causes of such trouble, yet relatively few are familiar with the poisonous plants found on their ranges.

The writers have chosen to define a poisonous plant as one containing some specific substance which, when eaten in sufficient quantity may produce a morbid, noxious, or deadly effect on the animal. When the result is only illness the effect is spoken of as toxic; and when death ensues the dosage is referred to as lethal. Merely mechanically injurious plants, such as some grasses, with prominent, penetrating awns, and those which occasionally cause bloat, like the clovers, are not included in this paper.

The chief object of this bulletin is to summarize the present knowledge and field observations of the stock-poisoning plants of the state. Although the total number of poisonous species occurring on ranges of California is large, most of the deaths among range livestock are caused by species embraced in relatively few genera.

In order to bring to the stockman's attention the poisonous species most generally harmful on the range, the material has been segregated into three parts. The plants of primary importance are discussed in the first section. Then those of secondary consideration are presented. The third section includes the plants which are more local or which cause only occasional livestock losses. When discussed at length the material under the first two groups is treated systematically under the following headings: Description and distribution of the genus; description of species; nature of injury and animals affected; and preventive measures. Maps showing in detail the distribution over the state of the more important species, accompany the deseriptive material.

1 Received for publication November 20, 1934.

2 Associate Professor of Forestry and Plant Ecologist in the Experiment Station.

3 Assistant Professor of Forestry and Assistant Forester in the Experiment Station; resigned June 30, 1935. 
A summary of the characteristics of the more commonly troublesome plants is tabulated in the back of this bulletin (table 2 ).

It is hoped that the bulletin will materially aid the stockman in recognizing the poisonous plants of his community. Not until these unwelcome species are known can stockmen expect to avoid pasturing dangerously infested areas.

\section{CONDITIONS OF POISONING}

Analysis of the records reveals the fact that livestock poisoning is more serious in certain sections of the state than in others. Observation of the distribution maps of the poisonous species reveals, in part, the reason for this.

Localized Poisonous Areas.-Many factors contribute to so-called regional or local poisoning. ${ }^{(76)}{ }^{4}$ Some poisonous plants, like black laurel and tree tobacco, are confined to rather definite climatic areas. Likewise, certain species, even when widely distributed, are more luxuriant and grow more densely in circumscribed climatic units or distinct soil types. Again, a poisonous species, because of very early maturity in one locality, compared with much later maturity in another, may cause severe losses in the first situation and virtually none in the other. Moreover, the characteristic declining toxicity of some species with the march of the season may synchronize well with declining succulence and decreased palatability of the herbaceous forage, so that losses may be light or they may not occur at all, unless the area is overgrazed. Such fortunate correlation sometimes occurs on larkspur-infested areas of some of our hill ranges. Then, too, regions which receive relatively heavy annual precipitation may harbor, on the lands of poor drainage, such dreaded plants as water hemlock. Also the elevational range of some poisonous species, like the toxic milkweeds, is such that livestock losses from this source are largely confined to the low hills or valley floors. In localities where prolonged cold rainstorms occur during the grazing season, as on elevated forest ranges in spring or early summer, or on bleak foothill ranges in winter, the animals may seek shelter for many hours at a time, emerging ravenously hungry. Then they do not select their food with the usual care and may overeat of unwholesome plants. Larkspur is sometimes the cause of heavy losses of cattle under such circumstances.

Where poisonous plants are particularly troublesome they usually occur in considerable abundance. The competing wholesome forage, formerly luxurious and dense, for one reason or another may now be sparse and low in vigor. Localized overgrazing generally favors invasions of

4 Superscript figures in parentheses refer to "Bibliography" at the back of this bulletin. 
unpalatable, and often of poisonous plants. Since the poisonous species are little eaten where ample good forage is available, they produce abundant seed, in opposition to that of the grazed forage plants and may invade contiguous areas where the desirable plant cover is thinned out. Numerous such instances have been observed. Certainly one of the most important single factors in controlling stock poisoning is that of maintaining at all times a vigorous growth of desirable food plants over the entire range.

Localized poisoning also may occur owing to the fact that the toxic substances vary according to the poisonous species present and the availability to livestock of the parts of the plant in which the poison occurs. In water hemlocks, for example, the poison is most abundant in the rootstocks and in the roots; therefore, livestock poisoning by this plant occurs most commonly when the soil is still sufficiently wet so that the rootstocks, which are fairly palatable, will be trampled or readily pulled out of the ground. In lupines, on the other hand, the poison is more concentrated in the seed, though the leaves of young plants may also be very toxic; hence there is more danger of poisoning by lupines in early spring, and again in the summer and fall, than during the intermediate period. In the nightshades, and in some other genera, it has been reported that individuals of a given species may vary greatly in toxicity, probably to the extent of causing much trouble in one locality and little in another. Keeping both stock and range in vigorous condition is therefore important.

Poisoning During Drought.-Periods of deficient rainfall tend greatly to increase the losses among livestock from poisonous plants. Areas not generally regarded as furnishing suitable pasture in seasons of normal rainfall, such as weed patches and waste places, are likely to be used. Among the plants especially dangerous during drought are those of the deadly prussic acid group, which includes both cultivated and wild plants. Those most dangerous, by virtue of their wide distribution and poisonous properties, are forage sorghum, Johnson grass, Sudan grass, chokecherry, and arrow-grass. When growth of these plants is interrupted, as by drought, wilting, frost, or even by defoliation such as by grazing, prussic acid in amounts lethal to livestock is likely to be formed. During some such disturbances a peculiar chemical reaction takes place between two substances, a glucoside and an enzyme, which results in the production of hydrocyanic (prussic) acid.

Those poisonous plants which retain their succulence and mature late in the season are particularly dangerous during drought. In seeking for a bit of succulent feed the animals are prone to consume lethal amounts 
of such poisonous species. During protracted dry periods animals maintained in foothill and valley may be poisoned from feeding upon such late-growing poisonous herbs. In the mountains various poisonous shrubs, notably chokecherry, laurel, azalea, Labrador tea, and rustyleaf, are most likely to be eaten in lethal amounts.

Stockmen who are provided with highly developed meadow lands, where pasturage may be made available during drought emergencies, are indeed fortunate. Serious attempts should be made to provide some such area on every livestock ranch.

General Precautionary Measures.-Avoidance of serious livestock losses from poisonous plants lies almost wholly in the field of prevention rather than in treating the diseased animals. Accordingly, it is well to keep in mind the following precautions as a general guide to holding the losses to the minimum.

1. Eradicate, where practicable, the toxic species by grubbing, frequent cutting, ${ }^{(2)}$ or by the use of suitable chemicals. ${ }^{(111)}$ Eradication by grubbing has proved feasible on areas where the poisonous plants are of perennial growth and occur in well-defined patches. In many wellknown instances the equivalent in value of livestock saved in a single year has paid for the cost of grubbing of dense patches of larkspur, or of pulling out water hemlock while the soil was still wet.

2 . Where the cost of eradication is prohibitive or impracticable, welldefined patches of poisonous plants may be fenced to prevent grazing. Such protection greatly favor's reëstablishment of the forage plants; and it sometimes results in practically replacing the poisonous species.

3. Drive or herd the animals slowly when transferring them from one part of the range to another. Hungry animals should never be driven through an area where poisonous plants abound. See to it that they are well fed before driving them over patches of poison. Cattle and sheep, when grazing quietly, tend to select wholesome food plants; but if driven rapidly when hungry they will often devour almost any vegetation along the path.

4. Graze the range as far as possible with the proper class of livestock. Since the various kinds of foraging animals select rather different species of plants for their diet, and since they differ in their susceptibility to plant poisoning, full advantage should be taken of these facts. Cattle are almost never extensively poisoned from death eamas, whereas losses among sheep are often heavy. Sheep are probably never poisoned by larkspur, whereas losses in cattle are frequently very serious. Accordingly, the ranchman should be informed as to the kind of livestock most likely to be seriously poisoned by the plants found on the 
area. If the owner has only one kind of livestock he should delay the use of at least the more seriously infested portion of the range until the most dangerous season is past.

5. Provide at all times ample salt and such essential minerals as are known to be deficient locally in the forage. Salt is regarded as a factor of some importance in preventing the animals from acquiring a perverted appetite, which may cause them to consume poisonous vegetation. Salt should be provided in a form which the animals can readily consume. Crystal sack salt, usually called stock salt or coarse salt, is gaining in popularity, particularly for cattle, for it can be so distributed that several animals can get salt at one time. Also, if it is known that the forage of the locality is deficient in certain minerals, such as calcium and phosphorus, sometimes indicated by the animal's chewing on old bones or eating dirt, these should be provided in suitable form, such as bone meal. Local practice in supplying minerals on the range should be followed.

6. Avoid too early seasonal use of the range. Grazing so early that the grass vegetation is still too short to afford a good "bite," especially on mountain range and meadows, is one of the most common causes of losses from poisoning. Such treacherous plants as death camas and larkspur are often the cause of exceedingly heavy losses early in the spring, that being the season of their greatest toxicity. These and certain other poisonous species start growth with the earliest of the vegetation and are often of fair size when the forage plants are still of low stature. Management plans should obviously provide for the grazing of a poisonous area when losses are least likely to occur.

\section{COMPOSITION AND PALATABILITY OF POISONOUS PLANTS}

In considering the poisonous effects of certain plants it becomes evident that the virulence of the poison is sometimes of less importance economically than is the quantity of herbage which the animal is likely to ingest. As pointed out elsewhere, animals seldom, if ever, consume poisonous plants by preference, but take them mostly in the absence of good forage.

Is there any one constituent, as has been asserted more recently, that imparts to plants that "something" which causes them to be eaten with gusto by foraging animals? Palatability is regarded by the writers of this paper as determined by several factors, such as physical characteristics, aroma, succulence, retention of the leafage on the stem after maturity of the plant, and chemical composition. In order to determine whether there are conspicuous differences in chemical constituents be- 


\begin{tabular}{|c|c|c|c|c|c|c|c|c|c|}
\hline \multirow{12}{*}{ 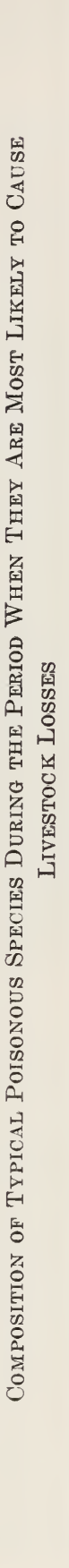 } & 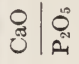 & $\overrightarrow{\mathrm{i}} \stackrel{10}{+\mathrm{T}}$ & $\stackrel{0}{=}$ & $\begin{array}{ccc}0 & 0 \\
-\infty & -1\end{array}$ & $\begin{array}{lll}\infty & 0 & N \\
-1 & \text { is } & \text { ov }\end{array}$ & $\stackrel{0}{\circ} \stackrel{0}{-1}$ & $\stackrel{\text { N }}{\rightarrow}$ is. & $\stackrel{\infty}{\infty}$ & $\begin{array}{l}0 \\
\dot{0}\end{array}$ \\
\hline & هั & $\begin{array}{l}\text { 구 } \overrightarrow{5} \\
00 \\
0\end{array}$ & 웅 & 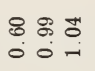 & $\begin{array}{l}\infty \\
\begin{array}{l}0 \\
0\end{array} \\
0 \\
0\end{array}$ & 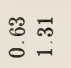 & $\begin{array}{ll}\infty & 0 \\
\infty & \stackrel{2}{0} \\
0 & 0\end{array}$ & $\begin{array}{l}\text { : } \\
0 \\
0\end{array}$ & $\begin{array}{l}\Re \\
0\end{array}$ \\
\hline & ర్జ & $\begin{array}{l}8= \\
0= \\
0=\end{array}$ & $\cong$ & $\begin{array}{ll}\delta \text { is } & \infty \\
0 \text { in } & =\end{array}$ & $\begin{array}{l}\infty \\
\infty \\
0 \\
0 \\
0\end{array}$ & $\dddot{2}$ & 요 & 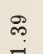 & $\overrightarrow{50}$ \\
\hline & 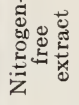 & $\begin{array}{l}\text { 유 8 } \\
\text { 맘 } 4\end{array}$ & $\begin{array}{l}\text { R } \\
\text { 일 }\end{array}$ & 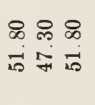 & 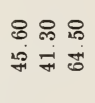 & 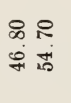 & 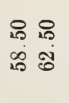 & $\begin{array}{l}\infty \\
\infty \\
\infty \\
\infty\end{array}$ & $\begin{array}{l}J \\
\infty \\
\infty\end{array}$ \\
\hline & 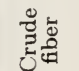 & $\begin{array}{l}\mathscr{B} \% \\
\dddot{\varpi} \\
\dddot{\sigma}\end{array}$ & $\frac{12}{6}$ & 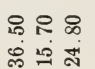 & 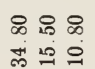 & $\begin{array}{l}\circ 9 \\
99 \\
99\end{array}$ & 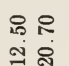 & $\stackrel{\infty}{\stackrel{\infty}{\circ}}$ & $\stackrel{\Re}{\rightleftarrows}$ \\
\hline & 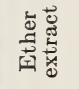 & $\vec{\infty} \infty$ & $\begin{array}{l}\text { \& } \\
\text { สं }\end{array}$ & 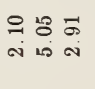 & 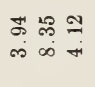 & 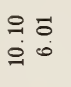 & $\begin{array}{l}\text { is ? } \\
\text { in is }\end{array}$ & $\begin{array}{l}\text { त् } \\
\text { a }\end{array}$ & $\begin{array}{l}\text { 고 } \\
\text { ๙ }\end{array}$ \\
\hline & 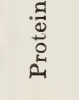 & 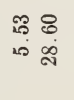 & $\begin{array}{l}8 \\
\text { สี }\end{array}$ & 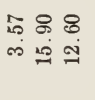 & $\begin{array}{l}\text { 유 오 오 } \\
\text { 처 }\end{array}$ & $\begin{array}{l}\text { 요 } 8 \\
9=\end{array}$ & $\begin{array}{l}8.8 \\
\& \infty \\
\therefore\end{array}$ & $\begin{array}{l}\vec{N} \\
\stackrel{\infty}{\leadsto}\end{array}$ & $\begin{array}{l}\infty \\
\infty \\
\text { జై }\end{array}$ \\
\hline & $\frac{5}{4}$ & $\begin{array}{l}\text { 오유 } \\
\text { is 풔 }\end{array}$ & $\begin{array}{l}R \\
\varrho\end{array}$ & 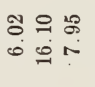 & 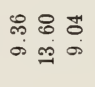 & $\begin{array}{ll}\infty & \infty \\
\infty & \infty \\
\infty & \infty\end{array}$ & $\begin{array}{l}80 \\
80 \\
\text { is in }\end{array}$ & $\begin{array}{l}\text { Sa } \\
\text { o. }\end{array}$ & $\begin{array}{l}\overrightarrow{0} \\
0\end{array}$ \\
\hline & 嵌 & $\begin{array}{l}28 \\
010 \\
i=10\end{array}$ & $\begin{array}{l}\infty \\
\infty \\
\infty\end{array}$ & $\begin{array}{l}\text { 유요 } \\
\text { is } 18\end{array}$ & 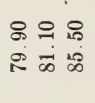 & 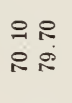 & $\begin{array}{l}\text { 요 } R \\
\text { A } \\
\text { S }\end{array}$ & & \\
\hline & 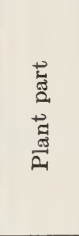 & 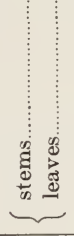 & d & 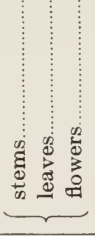 & 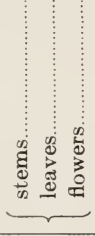 & 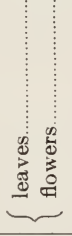 & 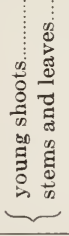 & 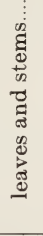 & 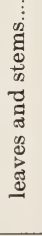 \\
\hline & 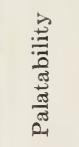 & 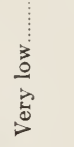 & بَ & 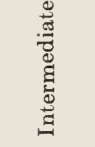 & $\frac{3}{0}$ & 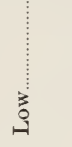 & 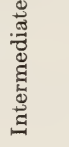 & 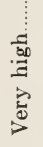 & 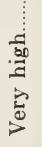 \\
\hline & 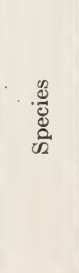 & 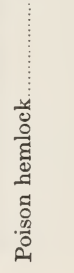 & 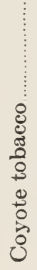 & 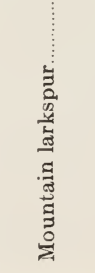 & 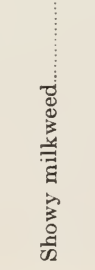 & 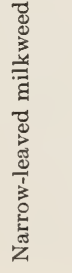 & 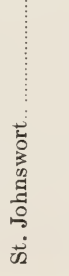 & 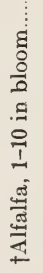 & 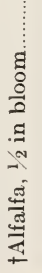 \\
\hline
\end{tabular}


tween relatively palatable poisonous plants and those of distinctly low palatability, analyses were made of several species. The samples were as nearly of the same physiological stage of development as could be procured. All were green and highly succulent, and in the early blossoming stage, presumably at the height of their palatability. In this study the highly palatable alfalfa plant was included for purposes of further comparison. The results are given in table 1.

Of the species analyzed, larkspur and the young shoots of St. Johnswort are much more palatable than are coyote tobacco and poison hemlock. The last-named is grazed by no domestic foraging animal except under distinctly abnormal range conditions.

The succulence, or moisture content, of the four species mentioned is very similar, as would be expected from samples collected in virtually the same growth stage. However, the fiber is lowest in the leaves of coyote tobacco, yet a limited amount of fiber is regarded as favoring palatability. It is interesting to note that the fiber content is nearly equal in amount in the stems and leaves of the mountain larkspur and the showy milkweed, plants which are at the upper and lower ends, respectively, of the palatability scale.

Likewise the protein content cannot be correlated with the palatability of the species analyzed. In the leaves of poison hemlock the crude protein is 28 per cent, whereas in those of larkspur it is only 16 per cent. Poison hemlock is conspicuously avoided by all kinds of domestic livestock, whereas larkspur is rather highly relished by sheep and is frequently eaten in goodly amounts by cattle. It is a matter of common knowledge that the palatability of grasses and other wholesome forage is greatest when the protein content is at or near the maximum for the season. High protein content, however, is usually associated with high moisture content. It is often difficult, therefore, to dissociate the effect of succulence on palatability from that of the protein content. Thus in St. Johnswort the protein content is very high in spring, a time when sheep and goats consume the shoots with some relish, whereas this constituent, as well as the moisture content, is low in the autumn, when the shoots are eaten little or not at all.

Several investigators, whose results are reviewed by Orr, ${ }^{(109)}$ have attempted to correlate the relative palatability of pastures with high mineral content of the forage. Their data, however, are far from convincing. In each instance it appears probable that the observations were made when the plants were in a different physiological stage of activity. It is well known that the chemical composition of plants varies greatly during the season of growth. According to the results reported in table 1, 
no correlation is seen in the matter of palatability and mineral content. Moreover, no correlation is found between the calcium-phosphorus ratio and palatability, which also has been suggested by some workers as a factor of importance in determining palatability. By way of comparison, the ratio $\frac{\mathrm{CaO}}{\mathrm{P}_{2} \mathrm{O}_{5}}$ in alfalfa is of the same order of magnitude as that of showy milkweed, despite the fact that the former is highly palatable and the latter is grazed scarcely at all, except under abnormal range conditions.

Referring again to table 1, another point of interest is the evident high food value of some of the poisonous plants as judged by the analyses. Alfalfa, when in beginning of bloom, contained between 16 and 18 per cent crude protein. The protein content of the poisonous plants analyzed was in many instances well above these values. Other organic constituents, as well as total ash, and indeed the calcium and phosphorus contents, compare favorably with those of alfalfa hay. Thus on the basis of the analyses alone, as here reported, it may be concluded that poisonous plants would afford nutritious forage if it were not for the poisonous substances present. The fact that most poisonous species are largely avoided by grazing animals, when other abundant forage is available, may be owing not to the proportions of the nitrogen and the ash, but more likely to certain compounds present in minute amounts. Whether certain alkaloids or glucosides of the poisonous species serve to repel the animals has not been determined. The importance of certain physical characteristics, however, must not be overlooked as factors in determining palatability. Obviously, further work on this phase is necessary to clarify the various phases of this general problem.

\section{PLANT POISONS}

A large number of poisonous substances of different properties, and of distinct reaction upon grazing animals, occur in plant species found our the range.

Most of the poisons belong to any one of the following chemical groups: saponins, glucosides, and alkaloids. Other plant poisons, like phallin, found in certain mushrooms, resemble bacterial toxins in their chemical and physiological behavior. They are, however, seldom the cause of extensive poisoning on the range.

The saponins, which embrace substances of glucosidal nature, that is, complex substances which have the common property of yielding a sugar when decomposed, contribute numerous compounds found in many higher plants. When dissolved in water and shaken they form a foamy 
mass resembling soap, from which the name saponin has been derived. Saponins have marked physiological action and toxic properties. Some react on the red corpuscles, causing hemolysis. Others affect locomotion and various muscles, notably those of the heart. Some saponins are used medicinally, among which is that of the foxglove (Digitalis purpurea), well known in treating diseases of the heart.

Among the glucosides, those plants which contain nitrogen in the form of prussic or hydrocyanic acid are conspicuous because of their quick action on the animal. These cyanogenetic glucosides, although less common than the saponins, are rather widely distributed in browse, forage, and fodder plants.

Alkaloids occur in plants mostly in the form of oily or crystalline bases. Quinine, strychnine, cocaine, nicotine, and conine are well-known alkaloids. Most alkaloids are decidedly bitter and repugnant to the human taste, but it is not known whether their presence in plants affects livestock in a similar manner.

The poisonous content may change markedly during the life cycle of the plant. It is also subject to variation with climatic changes. On the range, plants such as lupine, water hemlock, and laurel, which retain their poisonous properties during all or most of the foraging season, are most dreaded by stockmen.

\section{POISONOUS PLANTS OF PRIMARY IMPORTANCE}

Unanimity of opinion may not be found among investigators of the poisonous-plant problem of the state relative to which genera should be included in the list of "primary importance." Generally, however, the species of certain genera are so troublesome that classification according to the extent of losses on California ranges is not particularly difficult.

The larkspurs, St. Johnswort, death camas, lupines, and water hemlocks, are certainly of first importance. Those who have studied stockpoisoning plants in other western states might be surprised at the inclusion of the laurels and azaleas, and even of the milkweeds and tobaceos in this listing. The relatively heavy losses often caused by the last-named appears to justify their inclusion.

The placing of St. Johnswort second only to larkspur appears justified, not necessarily on the basis of the value of the animals which die from feeding on this plant, for the death rate is low, but because of the serious decline in grazing capacity of such infestations and the condition of the animals maintained on such areas. 


\section{LARKSPURS}

The larkspurs, also called cow poison and poison weed, probably cause more losses among cattle in the state as a whole than any other group of plants. Other domestic livestock are not seriously affected. The larkspurs, of which there are 16 species in California, ${ }^{(69)}$ are members of the buttercup family (Ranunculaceae), which embraces no genera or species of great value as forage.

Larkspurs may conveniently be divided into two general groups-tall larkspurs and low larkspurs. Because of the difference in the period of danger on the range more or less according to their growth habit, they are discussed on the height-growth basis. Only the species known to be poisonous are included in this discussion.

Description and Distribution of Tall Larkspurs.-The tall larkspurs of California are: coast larkspur (Delphinium californicum T \& G.), mountain larkspur (D. scopulorum Gray var. glaucum Gray), and cow poison ( $D$. trolliifolium Gray). The poisonous qualities of the tall larkspurs have been treated by various investigators, including the classical work of Marsh. (78)

The tall larkspurs are perennials 3 to 7 feet high, with many coarse, erect stems arising from a cluster of woody roots. The leaves are alternate, 4 to 6 inches broad, and divided into 3 to 7 lobes. The flowers, of many color shades of white, blue, and red, are irregular in shape and have a distinct spur which is often much longer than the petals. They are borne in racemes 10 inches to 2 feet long. The fruit is a many-seeded 3 -sided, glabrous follicle (plate $1 \mathrm{~A}$.)

Most tall larkspurs are shade-enduring and grow typically in welldrained, loamy soil of moist meadows or borders of springs and streams. They are common in damp mountain ravines and valleys, along creek bottoms, or on low hills.

Coast larkspur (plate $1 B$ and fig. 1 ) is the tallest, and the most widely distributed of our species. It is found on low hills near the coast and on the summits of the inner Coast Range, usually growing in association with succulent shrubs and buckeye. The flowering period is from March to July.

Mountain larkspur occurs between elevations of 5,000 and 7,000 feet (fig. 1). It grows sparsely in the higher mountains of its range, often in association with aspen. The flowering period is from June to September.

Cow poison, a common tall larkspur of other western states, is well confined in California in its northern distribution (fig. 1). Near the coast 
it grows on low, sparsely wooded areas. The flowers appear in late summer and they continue to unfold into early fall.

The tall larkspurs are not as troublesome in California as are the much more abundant low larkspurs.

Description and Distribution of Low Larkspurs.-Comparatively little experimental work has been done with low larkspurs but there is

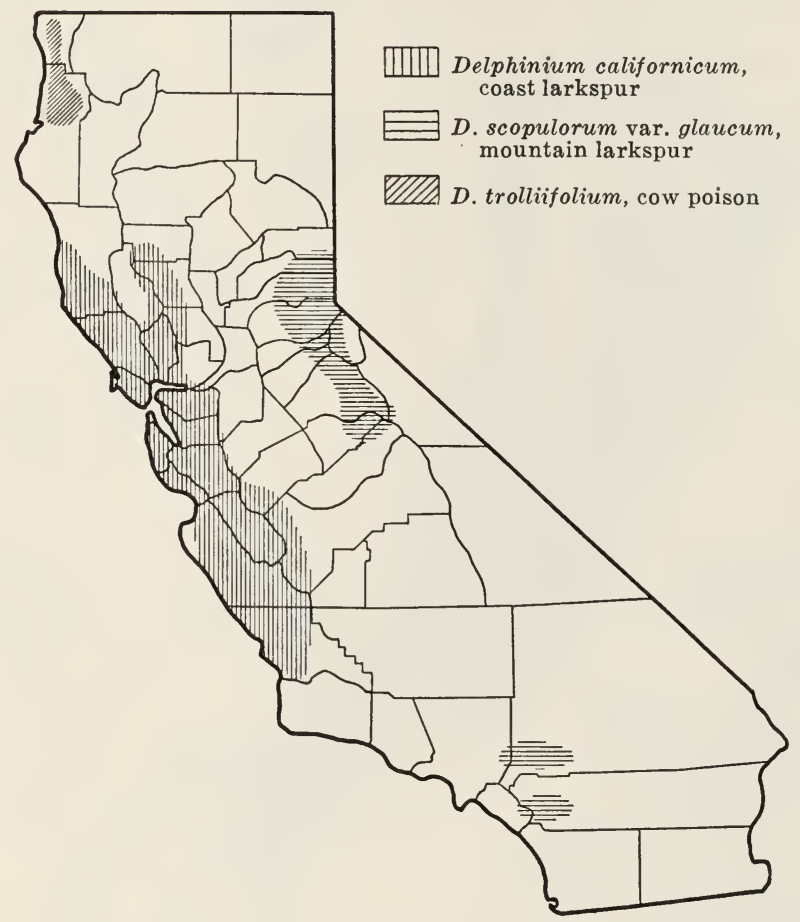

Fig. 1.-Distribution of the species of tall larkspurs which are known to cause livestock losses.

little doubt that all the species in California are poisonous. The species definitely known to cause poisoning are: western larkspur (Delphinium hesperium Gray), and the variety recurvatum Jepson; Menzies larkspur (D. menziesii DC.) ; smooth larkspur (D. decorum F. \& M., var. patens Gray); Parry larkspur (D. parryi Gray); and Anderson larkspur ( $D$. andersonii Gray).

The low larkspurs differ from the tall species in that they are seldom more than 3 feet high, averaging 11/2 feet, and having solitary or few stems. The leaves are thicker, smaller, and more finely dissected than those of the tall larkspurs, often with the edges of the divisions inwardly rolled. The flowers have the same range in color as the tall forms, with 
some pink. The roots are robust, like those of tall larkspurs, except in the species decorum and menziesii, which have fleshy tuberous roots. These two also have glabrous follicles (pods) like the tall larkspurs, while the other low larkspurs here discussed have hairy follicles.

The low larkspurs occupy a somewhat different habitat from the first group. They usually occupy dry open ground of the foothills, although they are found at fully as high elevations as the tall larkspurs (fig. 2).

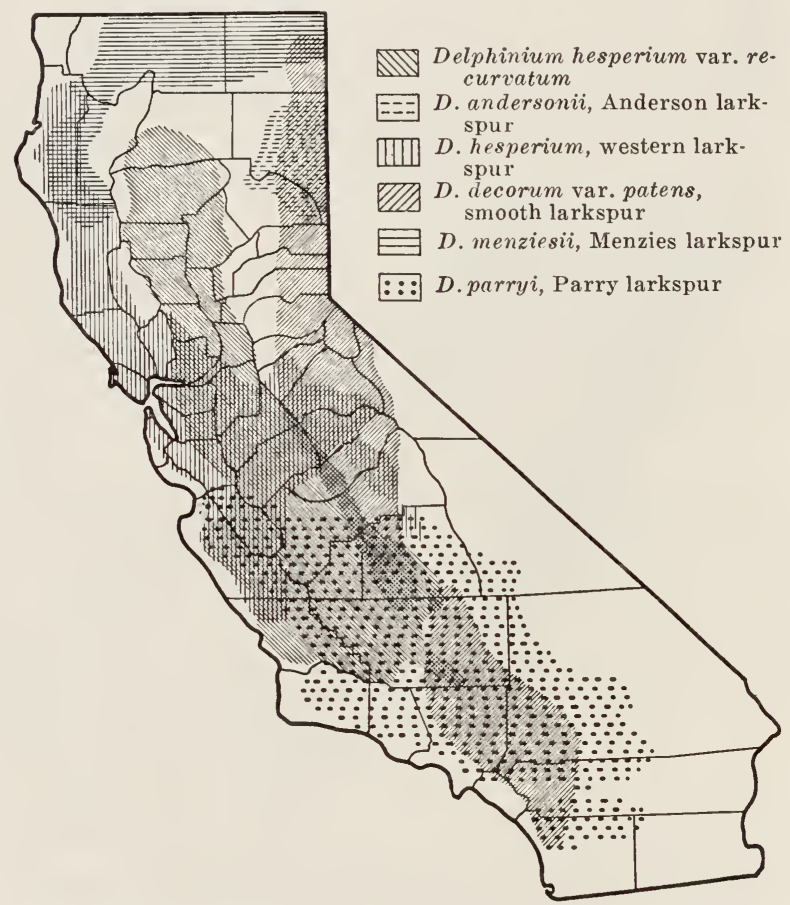

Fig. 2.-Distribution of the low larkspurs which are known to cause livestock losses.

Western larkspur grows from sea level near the coast to an elevation of 5,000 feet in the interior (fig. 2). In San Benito County it occupies ridges and high points instead of flat or low hills as on the coast, occuring in scattered stand to fairly dense cover of an acre or more.

In 1931 the authors received for identification a form closely related to western larkspur, named the variety recurvatum Jepson, from various places in San Luis Obispo County, with the complaint that it was killing eattle there. As early as 1898 Chestnut $^{(18)}$ reported that this plant was particularly fatal to animals in that county. The leaves of this variety usually have narrower and more acute divisions than the species. 


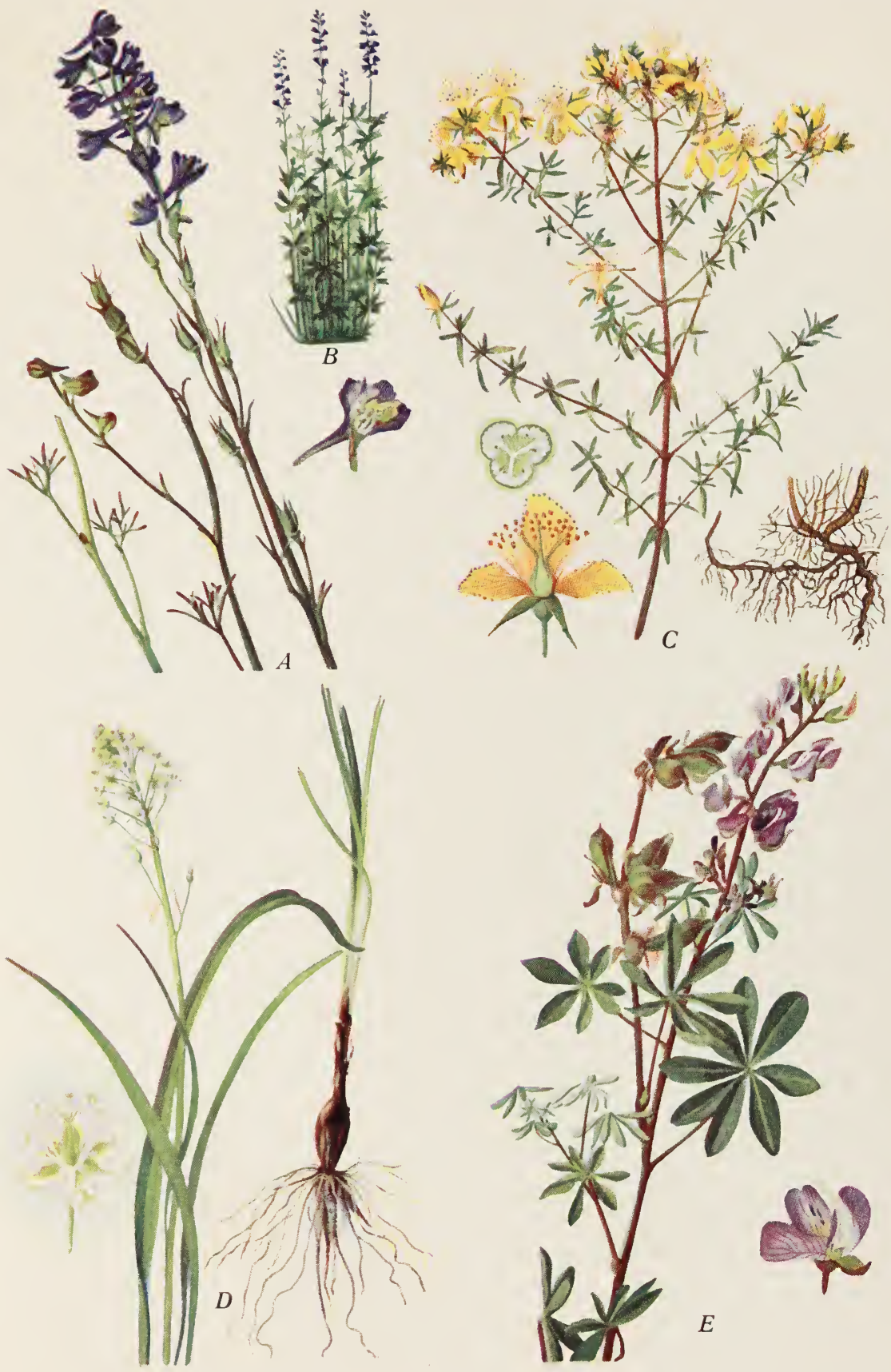

Plate 1.-A, Menzies larkspur (Delphinium menziesii), also showing detail of flower; $B$, coast larkspur (D. californicum); $C$, St. Johnswort (Hypericum perforatum); $D$, meadow death camas (Zygadenus venenosus); and $E$, grassland lupine (Lupinus laxiflorus). 

The flowers are white to pink and lavender, rarely blue, with recurving sepals. It is widely scattered throughout the state, being most common in low alkaline flats (fig. 2). The flowering period is from May through July.

Menzies larkspur, the second low larkspur mentioned, has been the subject of many feeding experiments in other western states because of its abundance and evident cause of livestock losses. In California it oceupies open hillsides to elevations of 7,500 feet or more (fig. 2). It flowers in March, or nearly as soon as the snow disappears, and continues through July.

Parry larkspur occurs at sea level along the es ,t and rolling hills, ${ }^{(1)}$ a few hundred feet in elevation in the interior (fig. 2). Specimens of this species likewise have been sent in by stockmen in San Luis Obispo and San Benito counties. Here numerous losses of cattle from feeding upon the plant have been reported during April and June.

Anderson larkspur is limited in distribution to semidesert country (fig. 2). This species has caused many fatalities anong eattle. ${ }^{(94)}$

Nature of Injury from Larkspur and Animals Affected.-In the seeds of one of the species studied, these two large groups of Delphinium, four alkaloids have been found in large amounts. ${ }^{(94)}$ Of these the most characteristic alkaloid appears to be delphinin. This poison acts upon the spinal cord, inducing depression and causing the animal to lose its excito-motor power. It has a gradual paralyzing effect upon sensitiveness, reflex power, respiration, and coördination of movement. The leaves and stems, however, and not the seeds are the parts generally eaten. ${ }^{(78)}$ The leaves are much more palatable and more poisonous, on a dry-weight basis, than are the stems.

Larkspurs, as stated, are very poisonous to eattle but are not seriously troublesome to other domestic foraging animals. Horses have been poisoned by feeding them large quantities, ${ }^{(2,}{ }^{94)}$ but there is almost no danger of death to horses on the range as they eat very little of it. Sheep feed upon larkspurs with some relish, with almost no losses resulting, even when held on badly infested areas. Goats also are practically immune from injury but generally feed little on these plants. If, however, large quantities of larkspur are taken when these plants are most toxic, any domestic grazing animal is likely to show symptoms of poisoning.

Fleming and Schapelle ${ }^{(46)}$ reported that an 800-pound cow must eat 25 pounds of either tall or low larkspur to cause death. But the stage of growth of the plant is not given. Feeding experiments by Clawson, ${ }^{(23)}$ using leaves and stems of a tall larkspur, Delphinium barbeyi (not found in California), revealed that three factors largely determined the quan- 
tity of larkspur that cattle must consume to be poisoned, namely, the part of the plant eaten, the age and condition of the plant, and the length of time the animal takes to devour a certain quantity. It has been stated that in some cases cattle have been poisoned on material corresponding to less than 3 per cent of their weight. ${ }^{5}$

In his most recent studies with this species, Clawson found that when leaves taken from fresh, healthy plants, before the flower buds were showing, were eaten by cattle within a period of about one hour, only 0.5 per cent of the animal's weight was likely to poison them, while 0.7 per cent of the weight might cause death. With greater age of the plant increasingly large quantities are required to cause correspondingly serious results. On a dry-weight basis, the leaves from plants, with the flower bud well formed, are about one-half as poisonous as are leaves from very young plants. Leaves from plants in flower are from one-third to one-fourth as poisonous, as are leaves of very young plants, and leaves from plants in fruit are only about one-sixteenth as poisonous. These differences in poisonous properties account largely for the heavy losses among cattle from larkspur poisoning in early spring.

Clawson succeeded in poisoning several sheep in a relatively short time-one of them fatally-by feeding them large quantities of the leaves of Delphinium barbeyi; but the dosage required was several times larger than that required for cattle. On the other hand, comparing leaves on a dry-weight basis, those taken from plants in fruit were about onehalf as toxic for sheep as were the leaves collected from young plants. Just why these plants do not lose their toxicity for sheep as rapidly as for cattle has not been explained. This peculiarity may account for certain losses in sheep on the range late in the autumn. In any event losses from larkspur poisoning among sheep occur limitedly and only under abnormal grazing conditions. As already implied, larkspur loses its toxicity with age, being most toxic when very young and immature, and least so after fruiting. The low larkspurs as a group flower early; therefore their tops soon die and disappear. There is danger, then, of poisoning from this group chiefly during March, April, and May. The somewhat later-maturing tall mountain larkspur and cow poison are dangerous for a longer period and are especially dangerous during inclement weather when the animals may become very hungry. After maturity there is little danger of poisoning, hence cattle may be grazed late in the season upon heavily infested areas. In some cases the tall larkspurs as a group are seriously poisonous only slightly later in the season than are the low larkspurs which grow in the same area. Late in the season,

\footnotetext{
${ }^{5}$ Correspondence with Dr. A. B. Clawson.
} 
therefore, even cattle may be grazed upon larkspur areas with relatively little danger, provided the species concerned have a definite growth cycle and are past the blossoming stage. Early grazing on recently burned chaparral areas often results in serious larkspur poisoning in the northern counties of the state.

The symptoms of poisoning are the same for all larkspurs. The animal first falls suddenly, and after violent struggles it may rise to its feet and walk away showing no further symptoms. If the poisoning is severe the first fall will be followed by a succession of falls, and finally by complete prostration, nausea, and death due to respiratory paralysis. ${ }^{(78)}$ Bloating sometimes occurs. ${ }^{(94)}$ Since poisoned animals are typically constipated, they will often recover if that condition is relieved.

Preventive Measures.-The poisoned animals, if down, should be turned with the head uphill to prevent regurgitated material from falling back into the windpipe. Although treatment with drugs is not generally practicable on the range, the following treatment has been recommended. ${ }^{(94,97)}$ The dose given applies to an animal weighing from 500 to 600 pounds. Twice the amount of the formula should be given to animals weighing 1,000 pounds or more. It is known as the physostigmine remedy and is administered hypodermically. The formula is :

Physostigmine salicylate 1 grain

Pilocarpine hydrochloride 2 grains

Strychnine sulfate $1 / 2$ grain

Where larkspur occurs in dense stands, especially the tall species, grubbing is successful and relatively inexpensive, ranging from $\$ 3$ to $\$ 10$ per acre. Larkspur areas may also be fenced to advantage to keep the animals off until after maturity of the plants; or sheep may be herded on an infested range to graze the larkspur until the stand of this plant has been destroyed to the extent of making the area safe for the pasturing of cattle.

\section{MONKSHOOD}

Monkshood or aconite (Aconitum columbianum Nutt.), also of the buttercup family, is often mistaken for tall larkspur, especially before blossoming, because the leaves and the habit of the plant are similar in appearance. However, monkshood may be distinguished, even in the early growth stage, by the petioles, or stem end of the leaves. The upper leaves of monkshood appear to have no petioles, for they are very short, whereas those of larkspur are conspicuous. Also, the stems of tall larkspur are hollow, whereas those of monkshood are pithy. In the blossoming stage it will be readily observed that the flowers of monkshood lack the charac- 
teristic "spur" of the larkspur, and instead have a helmet or hood which covers the two upper reduced petals. The flowers of monkshood and larkspur are often of the same bluish color.

It is important to distinguish between monkshood and larkspur because, although the former is a well-known poisonous plant, it seldom causes loss of animals by death. ${ }^{(78)}$

Monkshood is found in much the same habitat as tall larkspur and often they are closely associated. It occurs throughout the length of the Sierra Nevada from Modoc County, south to Kern County (probably further south also), into the mountains of New Mexico and Arizona, and west to Trinity County. In the Sierra Nevada it sometimes grows in dense stands.

\section{ST. JOHNSWORT}

St. Johnswort (Hypericum perforatum L.), is also called Klamath weed, cammock, speckled St. Johns, penny-john, herb of St. John, Johnswort, doolittle weed, goatweed, goat-beard, tipton weed, and rosin weed. It is a European exotic and is the only member of the St. Johnswort family in California definitely known to be poisonous to livestock. Of the four other species which occur in the state, only one, gold-wire (H.concinnum Benth.), has been suspected of poisoning livestock. Only $H$. perforatum is discussed here.

Description and Distribution.-St. Johnswort is an erect, freely branching perennial, 1 to 3 feet high. The leaves are sessile, oblong or linear with conspicuous dark glands or ducts on their margins. The main stem, arising from a woody base, bears many leafy, flowerless shoots, and ends in a thick cymose cluster of yellow flowers. Each flower is about an inch in diameter. The petals, like the leaves, have conspicuous black glandular dots near the margins. The fruit is a three-parted capsule containing minute dark-browll seeds (plate $1 C$ ). The flowering period is from June to September.

This weed has spread over many square miles in the northern part of the state (fig. 3). The earliest authentic observation of the plant by stockmen was approximately in 1900 , when scattered specimens were observed near Fort Seward.

St. Johnswort develops best in meadows and open rolling grasslands, where it occupies all slopes and exposures, and even secures a foothold on eroded areas. The soil may be fairly dry to moist, and is usually of an acid reaction. Since abundant sunlight favors the plant's best development, it grows weakly or not at all in the shade of heavy stands of timber, woodland, and brush. 
Nature of Injury and Animals Affected.-A viscid oily material found in the small glandular areas of the leaves, petals, and stems, known as hypericin, contains the toxic substance. ${ }^{(88)}$ The whole plant is said to be poisonous.

The poison causes physical exhaustion, dilation of the pupils, and increased heart action. Cattle, sheep, ${ }^{(88)}$ horses, ${ }^{(18)}$ and goats are affected, the last-named only mildly.

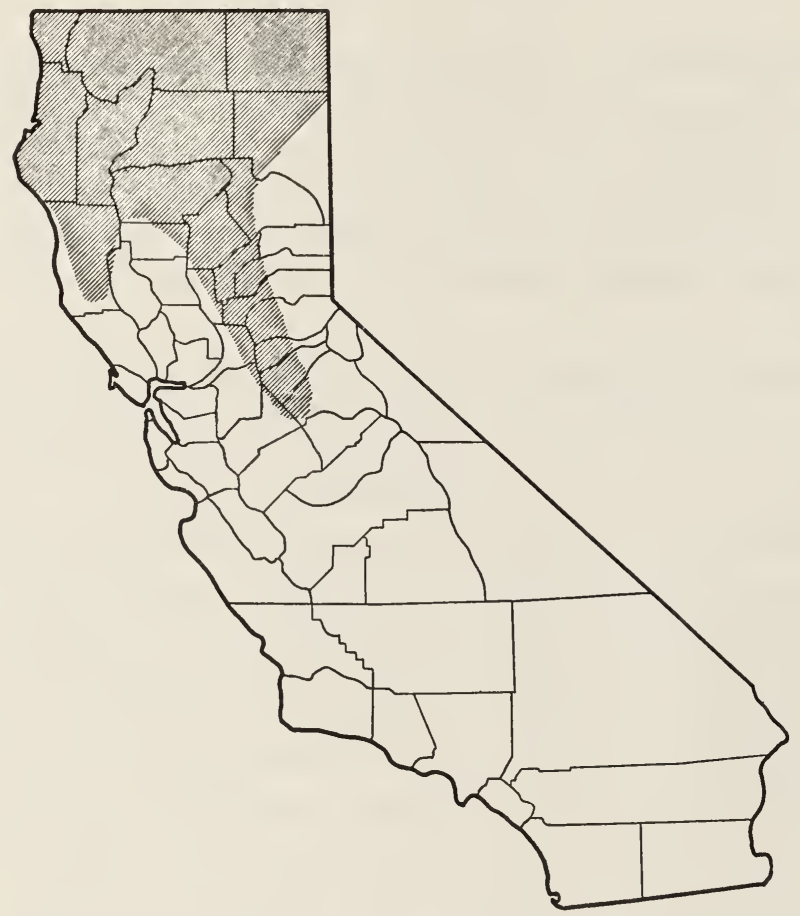

Fig. 3.-Distribution of St. Johnswort (Hypericum perforatum) in California, indicated by the shaded area.

The most noticeable symptom of poisoning is the blistery or scabby condition on unpigmented areas about the nose, muzzle, eyes, ears, feet, and other parts of the skin; that is, on those areas supporting white hair. Since the sores are confined to unpigmented areas, no dark-colored animals are affected. It is noteworthy also that the irritability of the scabs and blisters is stimulated or inereased by the presence of sunlight. When animals remain in full shade no blistering takes place, even though the plants are eaten freely.

Other symptoms of poisoning are : high temperature, rapid pulse, abnormal respiration, tendency to diarrhea, mild dermatitis, and sometimes salivation. ${ }^{(88)}$ Animals lose their sight in severe cases. Cattle are 
poisoned by consuming fresh St. Johnswort equivalent to 1 per cent of their weight, while 5 per cent may kill them. Sheep have shown symptoms from eating 4 per cent of their weight in one day. ${ }^{(88)}$ The symptoms appear from 48 hours to 3 weeks after eating a toxic dose. Deaths among livestock are not common but heavy financial losses are suffered since sores about the eyes and mouth make difficult the gathering of range forage. Badly affected animals are weak and in poor condition of flesh. ${ }^{(112)}$

Preventive Measures.-No specific remedy is known for St. Johnswort poisoning. Sheep, upon which large areas of scab have formed, should be sold, for the scar tissue permanently prevents growth of wool. Removal of affected animals to clean pasture is strongly recommended. In southern Australia, where large infestations now occur, a special breed of black sheep has been developed that are immune to St. Johnswort poisoning.

Eradication of the weed, by using chemical sprays if the infestation occurs in small patches, followed by deferred and rotation grazing, or followed by reseeding of very superior small areas to suitable cultivated forage plants, appears to be one means of coping with the problem. The weed grows little or not at all where a strong stand of grass occurs. Treatments such as cutting, flooding, burning, heavy grazing, and covering the ground of small areas as with building papers, are ineffective in control of this weed. Where practicable, cultivation is probably the most satisfactory method of destruction, but this is not possible on most range lands. Spraying thoroughly to cover the entire plant with sodium chlorate is effective and can be used to destroy small colonies. But these materials are too expensive for extensive use, and are dangerous if not handled with caution. Goats have been grazed on infested areas with good results to the range, for they keep the plant trimmed down. Overgrazing and destruction of the competing grass vegetation is probably the chief cause of the heavy infestations where the weed grows vigorously. Even if the St. Johnswort were destroyed by spraying it is probable that areas now occupied by this plant would soon become reinfested, provided overgrazing was not simultaneously discontinued.

The extensive infestations of St. Johnswort in southern Australia are being studied on the basis of biological control, through the use of insects introduced from the native habitat of the plant in Europe. To date positive results have not been secured. Control by insects may prove extensively beneficial, as it has in the case of prickly pear and certain other weed pests. Results of the Australian experiment are awaited in this country with much interest. 
At present entomologists of this country do not generally favor risking the introduction and liberation of insects for the purpose of destroying vegetation. It is held that even though certain insects are found to feed exclusively on a single weed in their native haunts, they might eventually adapt their food habits to valuable native or cultivated plants after the weed pest has been eradicated. There appears to be some hope that native insects will adapt their feeding habits to St. Johnswort, especially in view of the fact that certain insects are known to feed upon, and presumably hold in suppression, our native species of Hypericum. Already the rhubarb spittlebug (Aphrophora permutata) is commonly seen feeding on the stem of St. Johnswort; and in 1934 a conspicuous defoliation was observed to have occurred in a few patches of the plant by a cutworm moth (Drasteria crassiuscula). Whether the latter will succeed in spreading over St. Johnswort infestations to a point of economic importance is problematical. The entomologists and other research workers of the University of California are watching carefully developments in the general field of biological control of this weed.

\section{DEATH CAMAS}

Death camas, also somewhat commonly called poison sego, lobelia, zygadene, and sand-corn, are members of the genus Zygadenus in the lily family (Liliaceae). Of the five species found in California, the three included in this discussion are believed to cause most of the losses.

Description and Distribution.-Death camas plants are slender grasslike herbs with smooth, and mostly basal leaves, $1 / 6$ inch wide, and from 6 to 20 inches long. The stems are erect, from 4 inches to $31 / 2$ feet tall, and arise from dark or black, fibrous bulbs with paper-like covering, and found 2 to 8 inches deep in the soil. The greenish, or yellowish-white flowers, are borne in racemes 3 to 10 inches long, each flower having 3 sepals and 3 petals, similar in size and appearance. A green glandular dot appears at the base of each segment. There are 6 stamens. Numerous brownish-colored seeds are produced in a deeply 3-lobed capsule, from 1 to 1.3 inches long, to which the three short styles remain attached.

Species of death camas are widely distributed in California, occurring in the mountains and foothills, except in the interior and desert regions (fig. 4). They are most abundant in the northern part of the state.

Meadow death camas $^{6}$ (Zygadenus venenosus Wats.), reported to be

\footnotetext{
${ }^{6}$ Small meadow death camas (Zygadenus venenosus var. micranthus Jepson) is very similar to that of $Z$. venenosus. Small meadow death camas has a more open and broader flower cluster than the species. The flowers are larger and the glands on the petals are more prominent. The blossoming period is from April to June. It is confined to the Coast Range, where it occupies the major portion of the area covered by the species (fig. 4). It seems evident that the variety does not differ from the species in degree of toxicity.
} 
the most poisonous of all the species, is a slender plant, 8 inches to 2 feet high, with roughish folded leaves $1 / 6$ to $1 / 4$ inch wide. Its oblong-ovate bulbs, from $1 / 2$ to $1 \frac{1}{2}$ inches thick, are usually found about 2 inches deep in the soil. The flowering cluster is 3 to 10 inches long, narrow, unbranched, and compactly cone-shaped when young. The stamens have

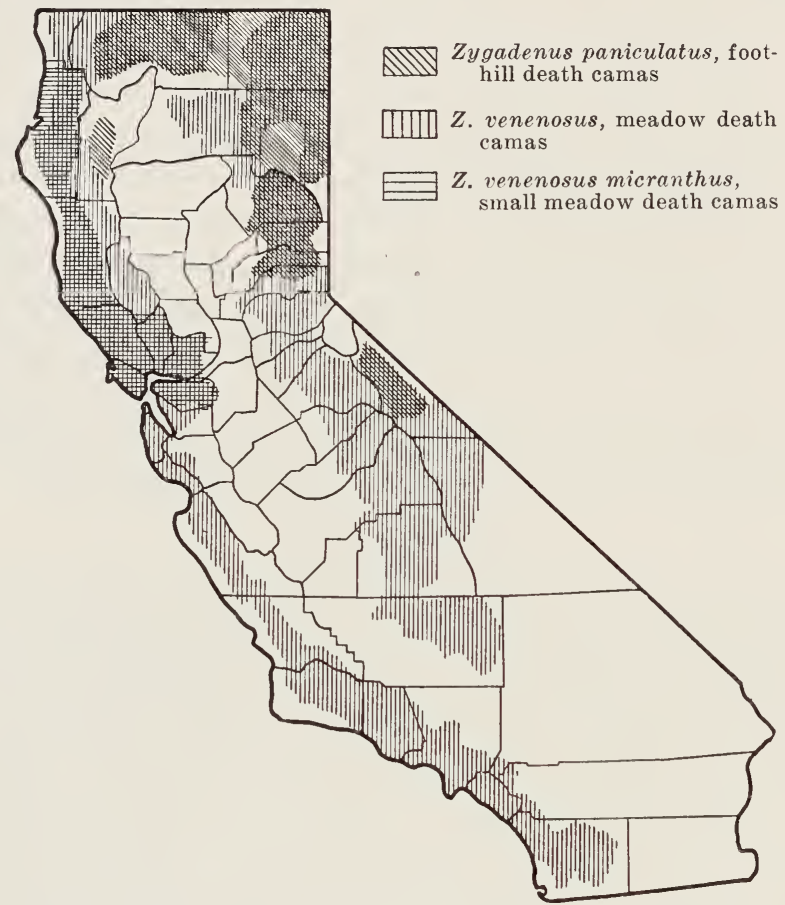

Fig. 4.-Distribution of species of death camas known to cause livestock losses in California.

white anthers. The fruit capsules measure $1 / 3$ to $1 / 2$ inch long (plate $1 D$ ). The blossoming time is from January at the lower elevations, to August in the high mountains.

Meadow death camas is widely distributed in the West, occurring from southern California, northward to British Columbia, and eastward to the Rocky Mountains. In California it is most abundant from Monterey and Mariposa counties northward (fig. 4), its altitudinal range being approximately from sea level in the Coast Range to 9,500 feet in the Sierra Nevada. The most favored habitats are wet mountain meadows, stream banks, and borders of bogs. Sometimes it grows in such abundance in mountain meadows as to poison hay cut there.

Foothill death camas, or sand-corn, the species Zygadenus paniculatus (Mitt.) Wats., closely resembles meadow death camas. Its stems, how- 
ever, are more robust, with all the leaves sheathing, and the bulbs are larger, the latter found 6 to 8 inches deep in the soil. The inflorescence is branched and open. The stamens have yellow anthers, and the seed capsules are from $1 / 2$ to 1 inch long. It often blossoms a month earlier than meadow death camas, as is observed when they grow in the same locality. Foothill death camas occurs between elevations of 1,000 and 9,000 feet, mostly east of the crest of the Sierra Nevada, thence north to Washington and eastward to Montana (fig. 4), and is common in the intermountain region. This species occupies exposed gravelly or rocky soils of hillsides and borders of dry meadows, where it is commonly associated with sagebrush and hard chaparral. Even though it is reputed not to be as poisonous as meadow death camas, it is responsible for sheep and cattle losses in the northeastern part of the state.

Star zygadene, or chaparral death camas (Zygadenus fremontii Wats.) closely resembles foothill death camas, and has several varietal forms. It is common in the lower foothills of the Coast Range and extends southward in California. It occupies mostly deep soils, often being found on the chaparral slopes, in the low woodland type, and open grassland areas in and adjacent to woodland. In some parts of the Coast Range, especially on the east slope bordering Sacramento Valley, the plant often occurs on burned-over chaparral lands. In some such recently burned areas sheep growers fear to graze their bands, since the losses have been heavy, probably owing to lack of suitable forage. Under ordinary conditions where star zygadene grows with an abundance of palatable forage it is eaten limitedly by sheep or other livestock and no losses have been reported. No experimental work, however, has been done to determine the toxicity of this species.

Nature of Injury and Animals Affected.-The poisonous substances, generally considered to be alkaloids of one form or another, are found in varying amounts in all parts of the death camas plant. ${ }^{\left({ }^{85}\right)}$ The seeds are very poisonous, with the bulbs next in order. Since the bulbs are seldom eaten by livestock the losses can be largely attributed to the poisonous substances contained in the herbage and fruiting parts. The amount of poison varies with the species, and probably it also varies within a species according to habitat. Variation in the amount of the poisonous substances, as well as the condition and susceptibility of the animals, determine the amount of plant material that may be consumed in order to cause sickness or death. The minimum lethal dose of meadow death camas for sheep is about 2 pounds of the green weight of plant for 100 pounds of animal weight, whereas the minimum lethal dose of foothill death camas is about $21 / 2$ pounds. In some cases $1 / 2$ pound of the leaves has caused sickness. 
Death camas, although believed to affect all domestic foraging animals, causes losses mostly among sheep. The losses among cattle are usually caused by foothill death camas. The amount required per 100 pounds animal weight to eause sickness does not differ materially from that for sheep. The amount of death camas required for sickness and death of horses has not been definitely determined. Although the plant is poisonous also to hogs, causing them to vomit, no losses are known to have occurred. Goats, also, are said to be poisoned by death camas but no deaths have been reported.

The symptoms of poisoning, which usually appear in 1 to 3 hours after the animal has taken a toxic or lethal dose, ${ }^{(85)}$ are much the same for all animals: notably frothing at the mouth, nausea with vomiting, weakness sometimes accompanied by nervousness, and collapse. The animal may lie without food for many hours and even days before dying.

Death camas is most dangerous early in the spring, especially on heavily grazed areas, for it produces vigorous early growth, usually in advance of the grasses and other desirable forage plants. At this season the soil is usually wet and loose and occasionally the animals pull up and devour a portion of the bulbs.

Preventive Measures.-There is no medicinal remedy for animals poisoned by death camas. Animals that become sick from this plant should be allowed to remain quiet; if undisturbed, recovery often follows. ${ }^{(93)}$

Losses may largely be avoided by recognition of the plant and preventing the animals from grazing infested areas during periods when poisoning is most likely to occur. Important precautionary measures to be taken are: (1) Avoid grazing badly infested areas early in the spring, especially where little wholesome forage is available; (2) do not trail hungry cattle or sheep across areas where an abundance of death camas occurs; (3) herd the sheep openly or loosely, since such handling enables the animals better to select their forage; (4) do not cut badly infested meadowland for liay.

\section{LUPINES}

Lupines are members of the pea family (Leguminosae), and are sometimes called wild pea, wild bean, Indian bean, old maid's bonnet, quaker's bonnet, and sundial. Some 65 species have been recognized as occurring in California. ${ }^{(69)}$

Description and Distribution.--Plants of the genus Lupinus are annual and perennial herbs or shrubs, 6 inclies to 6 feet high. The leaves have 3 to 17 leaflets arising from the ends like long, spreading fingers of a hand. Because of these distinct leaf characteristics, lupine could 
hardly be confused with other plants of the pea family. The typical pea flowers, borne as they are, in long terminal racemes or spikes, are showy and of various shades of blue, violet, white, yellow, and pink, often arranged in distinct whorls on the stems. The fruit is like a pea pod, con-

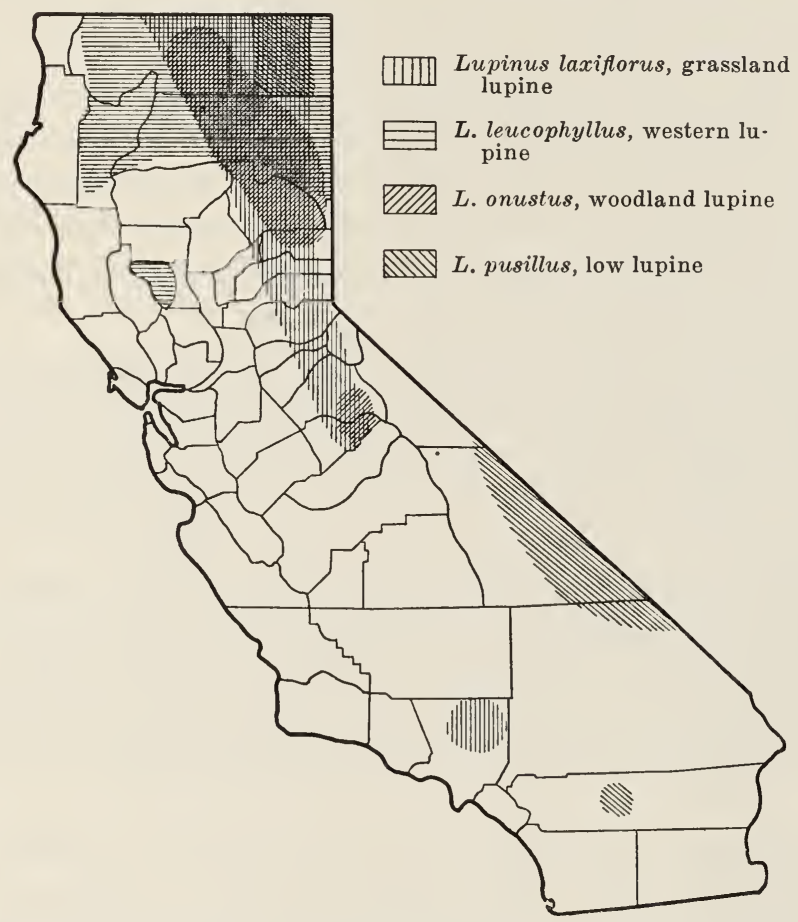

Fig. 5.-Distribution of the poisonous lupines in California.

taining from two to many seeds (plate $1 E$ ). Flowering occurs from April to August.

Lupines are found throughout California, growing in various habitats, from sea level to high altitudes, in moist to dry-even desert conditions-on plains, under shade of forests, or on open slopes. Even cultivated land is not free from them, since they often oceur in orchards and other tilled areas.

Many lupines in the western United States have been demonstrated to be poisonous, but only four of those species occur in California. These probably do not include nearly all of the poisonous species in this state since no experimental work has been done on lupines growing in California. For the present all lupines should be regarded as poisonous, especially early in the spring, and when in the fruiting stage. If the poisonous species were known it would be of little value in most cases, for 
the lupines are so much alike that even systematic botanists have much difficulty in distinguishing between them.

The four most common poisonous lupines in California are: western lupine (Lupinus leucophyllus Dougl.); ${ }^{(95)}$ low lupine (L. pusillus Pursh.); grassland lupine (L. laxiflorus Dougl.), and its varieties (plate $1 E$ ); and woodland lupine (L. onustus Wats.).

In California western lupine occupies well-drained mountain areas of fair to good grazing values from 3,500 to 5,000 feet in elevation (fig. 5). It is a common species in several western states. Everywhere it has been found to be poisonous to livestock. Frequently it has been eut and fed with hay with detrimental results. The flowering period runs from May to July, the pods beginning to mature in June.

Low lupine grows only 4 to 8 inches high. It is a very serious menace in some states, where sheep liave been poisoned from eating as little as 1 per cent of their weight. ${ }^{(51)}$ It barely reaches into California, being limited to the eastern part (fig. 5), where it occupies sandy soil of medium elevation. The flowers appear from April to July.

Grassland lupine is widely distributed in California (fig. 5), being most common in open woods and lillsides in the Upper Transition Life Zone, between elevations of 4,000 to 6,000 feet. The flowering period is from May to August. It has been reported by various investigators and stockmen as being poisonous, but experimental proof by feeding is lacking.

Woodland lupine has repeatedly been reported by California stockmen to be poisonous, but, as in grassland lupine, no systematic tests of its toxicity have been made. Its distribution in the state is fairly wide, although in the southern part it is confined to restricted areas (fig. 5). It is a species which occupies open pine forests between elevations of 5,000 to 9,000 feet. The flowering period is from July to September.

Early studies led to the conclusion that the toxic substances in lupine are alkaloids, of which lupinin and lupinidin are evidently primary. Another substance called ictrogen, believed to be the result of the growth of microörganisms upon the plant, has been discovered in European species. Some toxicologists have ascribed livestock losses to this substance. To date ictrogen has not been found in American lupines, but the study has not been exhaustive. The physiological effect of the alkaloids on the animals, namely, a tendency to paralyze the medulla or cord, corresponds well with the symptoms exhibited by livestock poisoned on the range.

Nature of Injury and Animals Affected.- Sheep suffer the most from lupine poisoning. Losses of sheep in America are known to be heavy, 
sometimes amounting to as much as 50 per cent of an entire band in a season. In losses caused by sheep poisoning, lupine ranks close second to death camas.

Cattle and horses are also known to be susceptible, but losses are seldom heavy. Even so, however, Clawson ${ }^{(22)}$ has shown that a variety, silvicola, of grassland lupine, is particularly dangerous to cattle. It is slightly less poisonous to horses, and considerably less toxic to sheep. Other animals known to be affected are deer, goats, and hogs.

In their study of Lupinus sericeum, Marsh and his co-workers ${ }^{(95)}$ found that the most dangerous part of the plant was the seed, which was from three to four times as poisonous as the other parts. For a 100-pound sheep the toxic dose was $1 / 4$ to $1 / 2$ pound of the seed, and the lethal dose was $5 / 10$ to $6 / 10$ pound. Of fully developed pods, but in which the seed was not quite ripe, it took $1 \frac{1}{2}$ pounds to produce acute poisoning or death in sheep. Lethal dosages for cattle and horses are not definitely known, but for some species at least they appear to be similar to those for sheep on an animal-weight basis.

Lupine leaves of some species are known to cause acute poisoning. Some are known to be very poisonous when young; and the leaves of at least some lupines appear to retain their toxicity throughout the season.

Hay containing an abundance of some poisonous species of lupine has repeatedly been reported to cause losses in sheep. When the feeding of such lupine hay was discontinued there was no more trouble. ${ }^{(21)}$ Reports of lupine-poisoned hay have been received from various parts of California. Since lupine poisoning is not cumulative, the animals may graze continually on the plants with no bad results unless the toxic limit is reached at any one time. ${ }^{(95)}$ In general, it may be said that the most dangerous season for lupine poisoning is that following their flowering period, heavy losses sometimes occurring when the plants are in fruit. It must be remembered, however, that there have been numerous fatal cases in early spring, before flowering, and also late in the season after much of the seed has been cast.

The symptoms, though differing somewhat according to the species eaten, consist of frenzied actions - the animals appearing to be crazed. They rush about in all directions butting against every object. Usually there is frothing at the mouth, difficult breathing, irregularity of movement, and falling fits, as though the animal were in violent convulsions. Often it dies during these attacks. Drooping of the ears is characteristic. Some animals become dulled and go into a deep sleep, from which they may never awaken. It is reported that cattle react to grassland lupine, variety silvicola, very much like they do to that of a tall larkspur, Del- 
phinium barbeyi, and that this has led to some confusion in diagnosing losses. ${ }^{7}$

Preventive Measures.-Stockmen should avoid turning animals into pastures where any kind of lupine is very abundant, especially early in the spring when the lupine leaves are young and also when the plants are in seed, unless the species concerned are definitely known not to be poisonous. Overgrazed areas, accompanied, as they often are, with poisonous lupines, should be utilized with caution. Sheep, particularly, should not be driven distances along trails through lupine areas, nor fed lupine hay which has been cut with the mature fruits on the plants. ${ }^{(51)}$ Eradication is generally impractical, hence prevention of losses on the range depends chiefly upon keeping the animals away from badly infested areas during the more critical periods.

\section{WATER HEMLOCK}

The water hemlocks, genus Cicuta, belonging to the parsley family (Umbelliferae), are reputed to be the most violently poisonous flowering plants of the temperate zone. Other common names for water hemlock are cicuta, cowbane, wild parsnip, poison parsnip, snakeroot, snakeweed, spotted hemlock, spotted parsley, beaver poison, musquash root, and muskrat weed. As far as known, all higher animals including domestic grazing animals, are poisoned by water hemlock. Many cases are on record showing that human beings have also lost their lives by eating small pieces of the rootstocks.

Four species ${ }^{(69)}$ oceur in California, all of which are regarded as equally poisonous. They are: Douglas water hemlock, Cicuta douglasii (DC.) C. \& R. (plate $2 A$ ) ; Oregon water hemlock (C. vagans Greene); California water hemlock (C. californica Gray); and salt-marsh hemlock (C. bolanderi Wats.).

Description and Distribution.-The water hemlocks are tall, smooth, branching perennials, with smooth, hollow stems 2 to 10 feet high, arising from rootstocks which may be short and erect, or horizontal and branching. These rootstocks are particularly characterized by a central hollow space divided by cross partitions forming distinct chambers. The leaves are simply pinnate (leaflets arranged along each side of the leaf stem or petiole), twice or even thrice pinnately divided, with sawtoothed edges. The small white flowers are in compound umbels, or in an umbrella-like arrangement, producing flattened, parsley-like fruits or seeds. The blossoming period is June through .July, but the fruits do not mature until September or October.

7 Personal correspondence with Dr. A. B. Clawson. 
Plants Confused with Water Hemlock.-Although water hemlock can usually be distinguished from other members of the parsley family by the definite chambers in the rootstocks, too much dependence should not be placed on this character for many species of the parsley family under certain growth conditions may produce similar partitions. Another character which is important in identifying water hemlock is the following : when the fresh rootstocks of water hemlock are severed, droplets of an aromatic yellowish oily appearing material exude, having a characteristic musty odor. If the freshly cut portion is placed in water, a thin oily film is seen on the surface. Such exudation does not take place with water parsnip or with other species likely to be confused with water hemlock.

Two plants commonly confused with the water hemlock are water parsley (Oenanthe sarmentosa Presl.) and water parsnip (Sium cicutaefolium Gmel.). They differ from each other in several respects. The herbage of water hemlock is greenish white, whereas that of water parsley is of a darker green. Moreover, water parsley differs from water hemlock in that the fruits of the former have a definite ridge on the commissure, or plane, by which the flattened faces of the two carpels cohere, and the styles are one-half or more as long as the fruits. In the water hemlock there is no ridge on the commissure, the styles are only one-fifth to one-third as long as the fruit, and the fruit is broad and roundish.

Water hemlock is distinguished from water parsnip chiefly in two respects : water parsnip has two or more oil ducts in the intervals of the fruit, instead of one as in Cicuta. Also the leaves of water parsnip are simply pinnate (leaflets arranged along each side of a common petiole), instead of the twice and thrice-pinnate leaflets of water hemlock.

Water Hemlocks in California.-The water hemlocks are confined to wet soils and salt marshes, "tule" swamps, stream banks, along irrigation ditches, or to low wet meadows, from sea level to about 8,000 feet elevation.

Douglas water hemlock, also known as western water hemlock and purple-stemmed hemlock, ${ }^{(110)}$ is found along mountain streams almost throughout California, from sea level to an elevation of 7,500 feet. It is commonly found at low to intermediate elevations in association with common parsnip (Oxypolis occidentalis) (fig. 6).

Oregon water hemlock has its center of distribution along the Truckee River, where it occurs from 5,300 to 5,800 feet altitude. It is limited in California to the east side of the northern Sierra Nevada (fig. 6). It may be distinguished from the other Californian species by the mature fruits. Mature fruits in this species have rows of corky ribs with intervals of 
yellow-brown color, whereas other water hemlocks have ribs and intervals of reddish brown.

California water hemlock is a coastal plant, and is confined to low elevations in the central coast area of the state (fig. 6 ). It is more aquatic than our other hemlock species, and grows in the water of rivers and

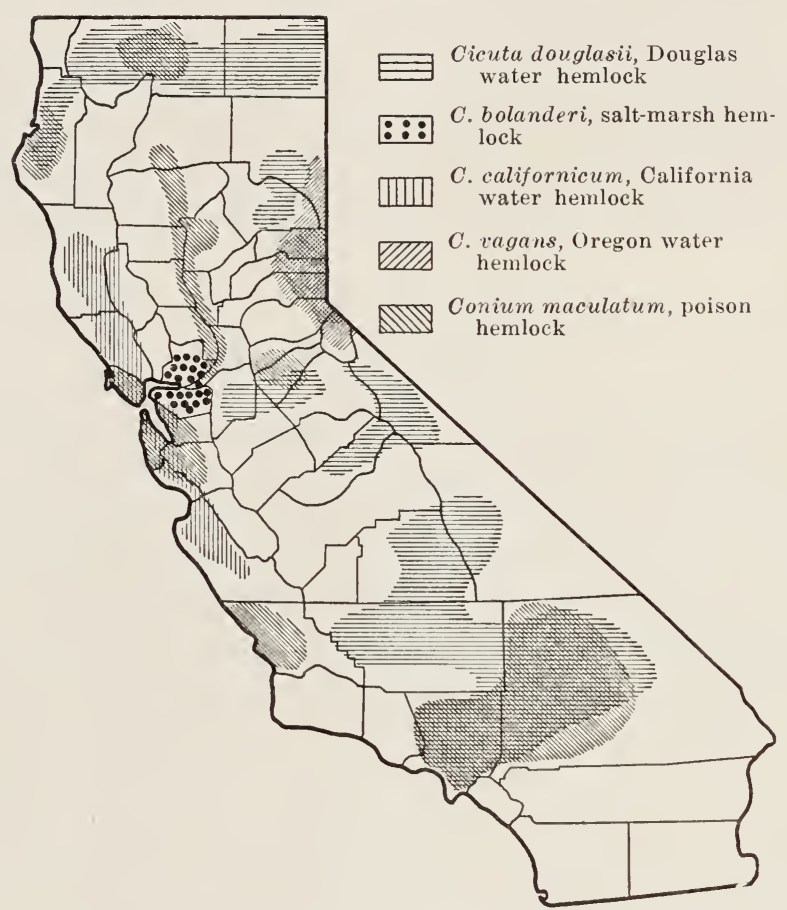

Fig. 6.-Distribution in California of water hemlocks and poison hemlock.

streams, not merely along the edges. It is essentially restricted to the Redwood Belt where it grows along the margins of eddies and in shallow waters of the shaded mountain streamlets. It is also common in the San Francisco Bay region.

California water hemlock is frequently mistaken for Douglas water hemlock, but may be distinguished by the leaves, which are simply divided, or partially twice divided. In the Douglas water hemlock they are two or three times divided.

Salt-marsh hemlock is an endemic species and although abundant, it is limited to marsh lands of Solano County (fig. 6). At Martinez it grows among tall reeds and sedges in loose, coarse soil. This plant is distinet from any other Cicuta because it is the only species which does not grow 


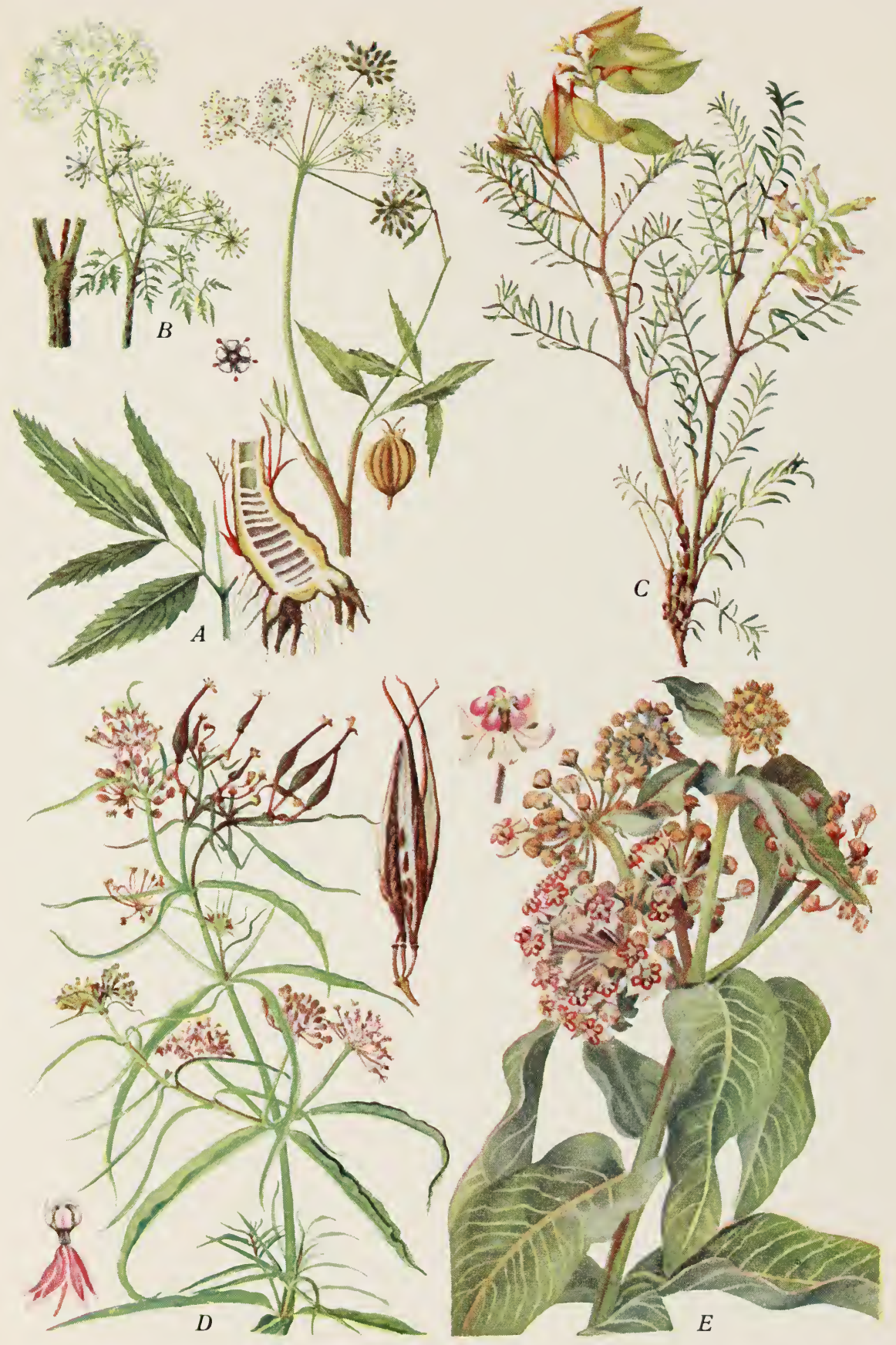

Plate 2.-A, Douglas water hemlock (Cicuta douglasii) ; B, poison hemlock (Conium maculatum); $C$, woolly-leaved loco (Astragalus leucophyllus) ; D, Mexican whorled milkweed (Asclepias mexicana); and $E$, woolly-pod milkweed (A. eriocarpa). 

in fresh streams. It is also the largest of the water hemlocks, seldom being less than 6 feet high and more often nearly 10 feet. $^{(55)}$

Nature of Injury and Animals Affected.-The oily appearing poisonous substance seen when one cuts across the rootstocks, is in reality a resin consisting of a bitter substance called cicutoxin and an alkaloid coniin. It is slightly soluble in cold water and in various other solvents. The poison affects particularly the central nervous system.

Although the old rootstocks are probably the most virulent parts of the plant, the basal parts, as well as the stems and leaves, contain sufficient poison, notably in the early stages of growth, to cause death. Where livestock have puddled the soil by trampling, the resin may be freed in sufficient quantity to produce poisoning if animals drink the pools of water.

Numerous cases of poisoning from water hemlocks have occurred in California. Because the water hemlocks occupy moist to wet soils, areas upon which sheep and horses are less likely to graze than cattle, the latter are most liable to be poisoned.

Symptoms of poisoning are typified by nausea and involuntary muscular movements, quivering of lips and nose, excessive salivation, and frothing at the mouth. ${ }^{(60)}$ This is followed by a series of violent convulsions during which there is groaning, clamping of the jaws with grating of the teeth, dilated pupils, backward bending of the head, and rapid kicking, or sometimes rigid extension of the legs. ${ }^{(45)}$ The pulse is weak and rapid, with labored irregular respiration. Generally there is diarrhea. The convulsions are intermittent and increase in violence in fatal cases. Bloating occurs in about half of the sheep observed, and in a lesser proportion of the cases in cattle.

Sometimes death ensues within fifteen minutes but more often in two or three hours after eating a toxic quantity. In less severe cases the animal lives for a day or two; or if the symptoms continue longer the animal may recover. The symptoms in man are similar but more marked. ${ }^{(92)}$

Fleming and co-workers ${ }^{(45)}$ found that not more than 2 ounces of freshly dug old tubers, and $1 / 2$ ounce of air-dried old tubers, quickly killed common range ewes. When these investigators fed $1 / 2$ to $3 / 4$ pound of freshly gathered tubers to cows weighing about 1,000 pounds, they died in a few hours. Two horses were fed 8 ounces and 15 ounces, respectively, of the same material and both were shot to relieve suffering.

At the Nevada station it was also found that it took from two to four times as much of new tubers as of old ones to eause death. ${ }^{(45)}$ Three ounces of the young shoots fed in February caused death, while 8 ounces were required in April. It has been found that the old tops are not dan- 
gerous, ${ }^{(92)}$ hence stockmen need have no fear of feeding hay containing them. They reported that 3.6 pounds per hundredweight of animal proved negative. The seeds are only slightly, if at all, toxic.

On December 28, 1933, the writers received a letter from Dr. C. S. Brooks, Hollister, California, which is so typical of water hemlock poisoning that it is here reported in part, as follows :

I was called today to investigate the cause of death of 18 weaned calves. All have died since December 15, as the owner went there to look after them and counted them on that date.

All had been dead at least three or four days and it appears they all died at about the same time, as we found 7 dead within a radius of a few feet and about 100 feet from where we found the hemlock.

These calves, 28 in all, were weaned the first part of November and turned into this canyon, which is the headwater of Bear Creek. There are several small glades in the canyon around the springs. It was at these glades that I found the hemlock and also found that the animals had been eating these roots. The animals have twice been vaccinated against blackleg. The posture of the carcasses was identical in each case. The head was drawn far back, the front feet had dug a small pit showing struggling, but of short duration; there had also been some kicking with the hind feet.

The tubers sent in by Dr. Brooks were found to be Cicuta, either Douglas water hemlock or California water hemlock. Both are very poisonous.

Preventive Measures.--Since the poison acts very quickly and the convulsions are violent, any remedy is difficult to administer. Hypodermic injections of morphine may be of aid in controlling the convulsions, giving sheep 11/2 grains and eattle and horses 3 to 10 grains. ${ }^{\left({ }^{22}\right)}$ Melted lard or any fatty substance may also be effective if given in the early stages of poisoning.

Because water hemlocks occupy wet ground they are easily and usually inexpensively grubbed or pulled out. All grubbed plants should be burned. Tubers left lying on the ground have caused fatal poisoning of cattle as much as three years after grubbing. ${ }^{(92)}$ Where grubbing is impracticable, as on brushy swamps, fencing of the infested area is recommended.

\section{POISON HEMLOCK}

Poison hemlock, or spotted parsley, Conium maculatum L., is distinct from water hemlock but also belongs to the parsley family. Because this species somewhat resembles the water hemlocks, it is designated by many of the same common names. It is poisonous both to man and to lower animals but in a milder way than the water hemlocks.

Description and Distribution.-Poison hemlock resembles water hemlock in that it is tall, erect, and hollow stemmed, and differs from it by having characteristic purple spots on the stems, and herbage with a dis- 
agreeable mouse-like odor and a nauseating taste (plate $2 B$ ). The leaves are one to two feet or more long, with finely-cleft (pinnatifid) leaflets, while those of water hemlock are less divided, that is, seldom more than twice pinnate. The flowers have the same color and arrangement but are subtended by circles of bracts or involucres, which are lacking in the other plant; and the fruits of poison hemlock have prominent wavy, but not corky ribs, and no oil tubes. The simple taproot usually lacks the distinguishing chambers of water hemlock. The flowering period is from May to September.

Poison hemlock, although indigenous to Europe and Asia, has spread until it is widely distributed throughout California and the northwestern United States. It is confined almost wholly to waste places, growing on moist, shady, or fairly dry ground, in fields and canyons, and along dusty roadsides. It is in no way semiaquatic like water hemlock. Although primarily a low-altitude species, the range in elevation is from sea level to 7,500 feet (fig. 6 ).

Nature of Injury and Animals Affected.-This plant is very poisonous and contains three principal alkaloids, conicein, coniin, and conydrin, the first-named being the most toxic. These alkaloids give the plant a burning taste and may account for its low palatability.

While all parts of the plant are toxic, the seeds are especially so, and at flowering time the leaves also are poisonous. The root is nearly harmless from March to May, but is dangerous thereafter, especially during the first year of its growth. ${ }^{(19)}$ The plant loses much of its toxicity when dry.

Poison hemlock is among the oldest known poisonous plants. There is some proof that this was the hemlock that was used to kill Socrates. Although very toxic, apparently affecting all domestic grazing animals and having killed many, this species is not nearly so troublesome as water hemlock. Losses from poison hemlock are few where good forage is available. Human beings have lost their lives by eating the seed and roots, mistaking the latter for parsnip.

The symptoms of poisoning from poison hemlock differ from those of water hemlock in that there is an absence of convulsions. A symptom in man is a gradual weakening of muscular power, often with the loss of eyesight. The mind usually remains clear until death. Domestic animals first show loss of appetite and signs of salivation. Bloating follows and the animal is in much pain. The pulse is rapid and feeble. Death follows, as in man, from gradual paralysis of the lungs. Fortunately, however, the plant is seldom eaten in amounts fatal to livestock except in the absence of suitable food plants: The greatest danger is in early spring, when the plant is most poisonous and slightly more palatable. 
There are no practical remedies for serious sickness from poison hemlock under range conditions. Prevention is the best means of controlling losses. Under farm conditions the same treatment may be used as for water hemlock.

Most important of all measures is that of maintaining a good forage cover at all times. Badly infested areas may be fenced against livestock if the losses justify it.

\section{LOCO WEEDS}

The loco weeds, genus Astragalus, certain species of which are called rattle weed or crazy weed, are members of the pea family (Leguminosae), to which belong many excellent forage plants. All domestic foraging animals are poisoned by these plants.

Description and Distribution.-Loco weeds are either erect or semiprostrate, annual or perennial herbs, and are mostly glabrous to white in appearance (plate $2 C$ ). The leaves are compound, with many small leaflets attached on each side of the leaf stem, and with an odd leaflet at the end. The characteristic pea flowers are borne in crowded racemes, spikes, or heads in various shades of purple, yellow, white, or red. The most striking feature is the fruit, which is a pod, either inflated and bladder-like or flat and compressed, containing two to many small seeds.

Loco weeds are found in various kinds of grazing grounds. They are not as common in California as in adjacent states. They grow in thick sagebrush, open woods, on barren rocky ledges, or semidesert ranges, from sea level to high mountain peaks. Since comparatively few cases of loco poisoning have been reported in California, it may be that most of our species are either not injurious or they are harmful only under certain conditions, ${ }^{(60)}$ or, possibly, the losses inflicted have been credited to other plants. Moreover, although there has been considerable experimental feeding to determine which species are poisonous, none of the California weeds have been used. Therefore, all species in the state had best be regarded with suspicion. Several authorities, however, have published reports of the toxic properties of sheep loco (Astragalus hornii Gray), gray loco (A. menziesii Gray), Morton loco (A. mortoni Nutt.), and spotted loco (A. lentiginosus Dougl.). Evidence points to the fact that these species have caused livestock losses in California. Three other species, namely, smooth loco ( $A$. ö̈carpus Gray), woolly-leaved loco (A. leucophyllus T.\&G.), illustrated in plate $2 C$, and tufted loco ( $A$. purshii Dougl.) are also considered poisonous ${ }^{(69,72)}$ although at present there is little certainty of their causing losses in this state.

Sheep loco is probably one of the most dangerous species in California-Marsh, ${ }^{(72)}$ Chestnut, ${ }^{(18)}$ and Pammel, ${ }^{(110)}$ having mentioned 
investigations proving its destructiveness. It is a prostrate, spreading semidesert species growing on hot, dry, sandy, or gravelly slopes at low or middle altitudes, only seldom being found above 5,000 feet elevation. The flowering period is May and June. It is confined to southern California (fig. 7), thence east to Utah.

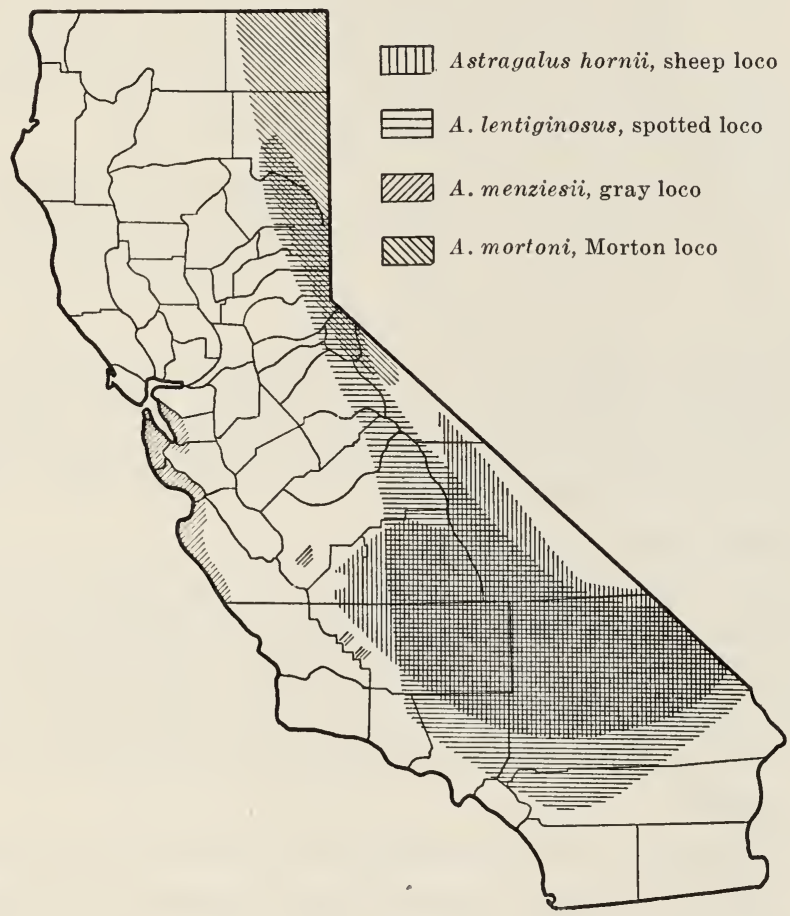

Fig. 7.-Distribution of the species of loco.

Gray loco is a middle-California coastal species (fig. 7), common in meadows, sandy fields, and slopes along the immediate seaboard, never being found far from the coast. As early as $1875 \mathrm{Kellogg}^{\left({ }^{70)}\right.}$ stated that thousands of horses, cattle, and sheep had been poisoned by gray loco in California.

Morton loco is a northern-California species (fig. 7) most common in moist soil up to 7,000 feet elevation. This species has been referred to by Marsh ${ }^{(72)}$ and others as very poisonous.

Spotted loco is confined to the east side of the Sierra Nevada (fig. 7). It grows on dry plains and meadows, sandy deserts, exposed slopes, or under pines up to altitudes of 9,000 feet. The heaviest stands are found at about 4,000 to 5,000 feet. Flowering occurs from July to August.

Nature of Injury and Animals Affected.-Little is known of the toxic principle of loco plants. At one time the poison was thought to come 
from the metal barium, which the plant seemed to absorb in toxic quantities from the soil, but this was disproved. Experimental work indicates that the entire aerial parts carry the poison. ${ }^{(104)}$ It is not known which of our California species are most troublesome. Young animals are more susceptible than are adults. Some investigators ${ }^{(71, i 2)}$ have found that horses are particularly affected. All agree that sheep and horses are more likely to become locoed than cattle. Most of the domestic grazing animals are susceptible to the formation of a loco habit, which, thereafter, makes them select loco in preference to good forage.

The symptoms produced by true loco weeds are similar in all livestock and usually do not appear until the animals have fed upon the plant over a fair part of a grazing season. The animals first become dull, although steers will sometimes become frantic and run widly into obstructions. There is weakness and lack of muscular coördination, which merges on paralysis. Sheep show these tendencies more than do other animals. A locoed steer violently shakes its head, and when suddenly alarmed, will rear and jump backward. A horse often falls over backward when frightened.

Animals also become solitary and stand in one position for hours. Their coats become rough, they lose weight, and finally they fall and die from thirst and starvation. ${ }^{(78)}$ Sometimes acute poisoning kills an animal within a few days or weeks, but usually the animal lives from three months to a year, showing the same symptoms as in the acute form, but to a milder degree.

Preventive Measures.-Animals should first be moved to a place where they cannot eat loco weeds. Since àll locoed animals are constipated, diseased individuals should be given laxative food, such as alfalfa. Recovered animals should not be grazed on ranges infested with loco weeds, as they may soon again acquire the habit. Moreover, since loco-weed eaters may teach other animals the habit of feeding on these plants they should be separated from the herd.

Prevention of overgrazing on loco-infested ranges is recommended. M. W. Talbot, ${ }^{8}$ following a survey of the loco disease trouble in the Southwest, concludes: "Most of the stockmen interviewed believe that food scarcity resulting from overgrazing increases the likelihood that an animal will acquire the loco disease. And quite apart from its undetermined relation to loco-weed abundance... overgrazing is strongly to be condemned."

8 Unpublished report on loco-weed conditions in southern New Mexico, on file in Bureau of Animal Industry, United States Department of Agriculture, Washington, D. C. 
Horses, when locoed, are benefited by being given daily doses of 4 to 6 drams of Fowler's solution; cattle by hypodermic injections of $3 / 20$ to $4 / 20$ of a grain of strychnine; and sheep by $1 / 20$ of a grain. These doses should be continued for a month. ${ }^{(78)}$

Prevention may be accomplished by furnishing supplemental feed during periods of shortage of forage. Most important of all, however, is that of keeping the animals away from infested areas.

In parts of the West some of the perennial locos have been eradicated by grubbing out the crowns and surface roots 2 to 4 inches below the ground surface; $;^{(7 \tau)}$ but since the plants often occur in scattered stands such treatment is not always practicable. It is best to do a little experimental grubbing before attempting it on a big scale.

\section{MILKWEEDS}

The milkweeds, so called because of the copius milky juice in the foliage, are members of the milkweed family (Asclepidaceae), and the genus Asclepias. Losses of sheep from milkweed poisoning have often been serious.

Description and Distribution.-Innumerable plants contain milky juice but they should not be confused with species of Asclepias. True milkweeds are perennial herbs with stems commonly erect, arising from thick deep-seated roots. The leaves may be opposite or whorled, linear or broad. Awl-shaped bracts embrace the flower cluster. The calyx is 5-parted, the corolla 5-lobed, and their segments reflected, those of the former being small and persistent, while those of the latter are deciduous. The filament columns (of anthers) bear a circle of 5 hoods, each hood usually containing an incurved horn (plate $2, D, E$ ).

There are 11 species of milkweeds in California. Although some are apparently harmless, the poisonous properties of so few species have been determined that all should be suspected. They may be separated into two groups : broad-leaved milkweeds, and narrow-leaved or whorled milkweeds.

The broad-leaved milkweeds are perennials 1 to 6 feet high, with tough bark and with leaves opposite or in whorls. These, in contrast to the leaves of narrow-leaved milkweeks, are large, measuring $1 / 4$ to 4 inches in width, and $2 \frac{1}{2}$ to 8 inches in length. They are usually densely woolly. There are numerous, showy, flower clusters, yellowish pink, green, purple, brown or white-tinged in color, borne in terminal umbels. The flowers have the characteristic erect, hooded appendages and pendulant sepals and petals. The fruits are large, thick-skinned follicles, enclosing numerous reddish-brown seeds, each with a long tuft of silky hair at the apex. 
These milkweeds are widely distributed throughout the state. They are found principally on dry hills and in barren valleys of low elevation, reaching the ponderosa pine and fir association of the Sierra Nevada and mountains of southern California. Out of eight broad-leaved milkweeds in California, there are only two whose toxicity has been experi-

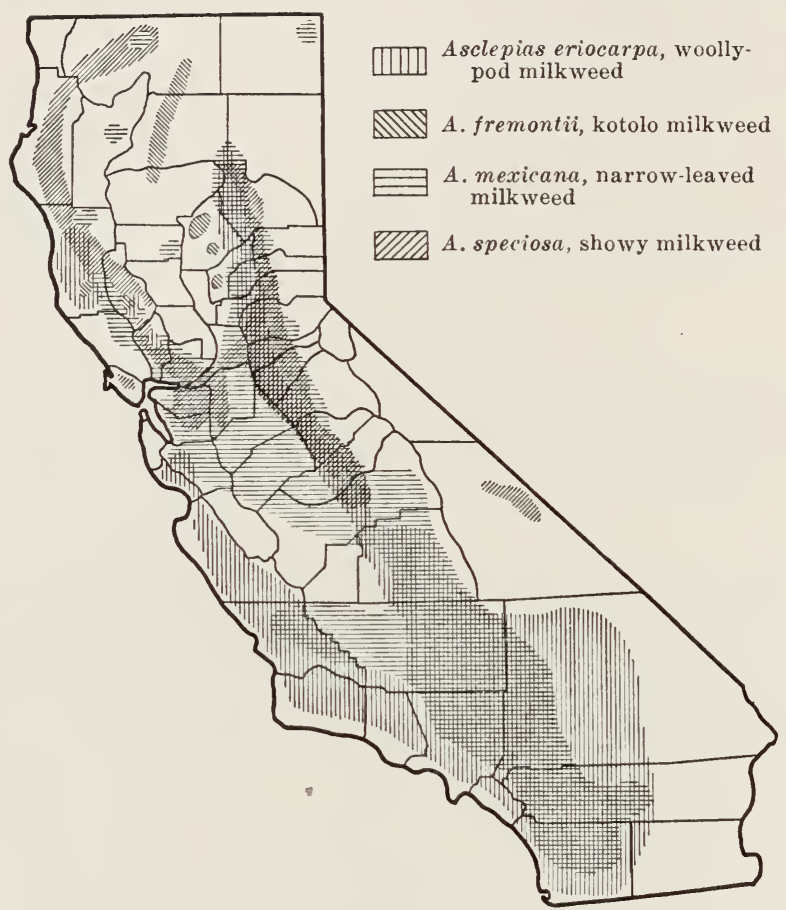

Fig. 8.-Distribution of the poisonous milkweeds.

mentally proved. Kotolo (Asclepias fremontii Torr.), has been considered very poisonous by some authors, ${ }^{(78,113)}$ but too little is known about its poisonous properties for discussion (fig. 8). Heart-leaved or purple milkweed, A. cordifolia (Benth.) Jepson, also has often been suspected, although Fleming and co-workers ${ }^{(42)}$ report that it has produced no poisonous effects. The two whose toxicity have been proved are woollypod milkweed (A. eriocarpa Benth.), illustrated in plate $2 C$, and showy or creek milkweed (A. speciosa Torr.).

Woolly-pod milkweed ranges from northern to lower California, but its center of distribution is southern California where it extends across the full width of the state (fig. 8). It flourishes best in sandy soil in hot, exposed habitats, on mesas and in valleys, up to 6,500 feet in the mountains. 
Showy or creek milkweed occurs in the northern and western middle portions of the state, from sea level to 10,000 feet.

It prefers moist soil in cool, shady places, often being found near streams, lakes, or rivers, or in meadows, where it is troublesome. Occasionally it is found in grain fields and gardens. ${ }^{(110)}$ It flowers from May to September, principally in June and July.

Showy milkweed is easily distinguished from other broad-leaved milkweeds because it is the only species whose seed pods are spiny. Its leaves are always opposite, while those of woolly-pod milkweed and kotolo are sometimes in whorls. Also it has the largest flowers of any of the milkweeds.

There are three milkweeds in California of the narrow-leaved form, but only Mexican whorled or Mexican narrow-leaved milkweed (Asclepias mexicana Cav.), is known to be poisonous. This species differs conspicuously from the two broad-leaved species, namely woolly-pod and showy milkweed, in that its leaves are long and linear, measuring but $1 / 16$ to $3 / 4$ inch in width (plate $2 D$ ). Furthermore, they usually fold together at the midrib, making them appear even narrower. Other differences are: the leaves occur in whorls, the herbage is glabrous, and, compared with the broad-leaved milkweeds, the species has very small flowers. These are greenish white in color or tinged with purple.

Mexican whorled milkweed is the most widely distributed species in California and occurs throughout the state except very near the coast (fig. 8). It is a typical foothill or lowland species, usually growing in patches in barren valley fields, low plains and hillsides, and sometimes at an altitude of 6,000 feet in the mountains. It often forms clumps 3 feet high in the scrub-oak belt, being associated with chamise, Christmas berry or toyon, mountain lilac, and madrone. The flowering period is the same as that for the showy milkweed.

Nature of Injury and Animals Affected by Broad-leaved Milkweeds.The different species of poisonous milkweeds differ as to the degree of toxicity of the various parts of the plant which contain the toxic principle. The leaves and stems of woolly-pod milkweed appear to be equally toxic, ${ }^{(42)}$ and they are dangerous in the dry as well as the fresh, green state. Apparently when dry, woolly-pod loses its disagreeable flavor, but not its poisonous character, and thus may be dangerous when found in hay. ${ }^{(42,86)}$ This species of milkweed is regarded as the most poisonous in California. The dosage for cattle and for sheep is practically the same. As little as 0.1 pound per hundredweight may cause poisoning, and 0.22 pound may cause death. ${ }^{(86)}$

With showy milkweed, large amounts of the leaves are required to cause poisoning symptoms. The empty pods are more toxic than the 
leaves, while the seeds are the most dangerous of all parts. Fleming and co-workers ${ }^{(42)}$ found that $21 / 4$ pounds of green leaves of showy milkweed would cause poisoning of a mature sheep, while the same amount of green pods would kill the animal. Using seeds alone, even $1 / 2$ pound was sufficient to cause death. It is reported, however, that when dried naturally in the field, showy milkweed loses part of its poisonous properties.

The symptoms of poisoning caused by the various broad-leaved milkweeds are similar, and are very distinct from those caused by eating the narrow-leaved species. They appear from 3 to 22 hours after feeding on these plants. The animal becomes depressed and dull; the head is lowered and the back humped; the breathing becomes irregular and the temperature falls. This depression is followed by weakness, and the animal lies down. In severe cases there is difficult breathing, groaning, and some evidence of pain followed by a period of high temperature and diarrhea. ${ }^{(86)}$ As the animal grows weaker, breathing becomes more difficult. Death comes quietly. Unlike poisoning caused by narrow-leaved milk-weed, there are no spasms and no period of coma. If the animal recovers it is a gradual process and may require a week or more.

Nature of Injury and Animals Affected by Narrow-leaved Milliweeds. There is evidence that the poison of narrow-leaved milkweeds is found. largely in the leaves. The stems and pods are next in degree of toxicity, ${ }^{(42,80)}$ respectively. Mexican whorled milkweed, like the woolly-pod, is also dangerous when dried, hence is a menace in hay.

Mexican whorled milkweed is apparently only one-fourth as toxic as woolly-pod milkweed. ${ }^{(80)}$ Fleming and co-workers ${ }^{(42)}$ found that mature sheep are poisoned from eating $1 / 2$ to $11 / 2$ pounds of it in the green state, and that they are likely to be killed by any amount in excess of $1 \frac{1}{2}$ pounds. Fleming also found that for yearling animals from 2 to 5 pounds of the green plant are dangerous, while more than that is usually fatal. ${ }^{(42)}$

Of the dried plants, from 5 to 16 ounces is usually enough to make mature sheep sick, more probably causing death. ${ }^{(42)}$ With yearling animals, amounts in excess of $3 / 4$ pound of the air-dried plants are highly dangerous. Marsh and Clawson ${ }^{(80)}$ give 0.353 pound per hundredweight of sheep or cattle as the minimum toxic dose, and 0.882 pound as the minimum lethal dose.

Rabbits, and probably also horses, are poisoned from eating milkweed. ${ }^{(86,21,42,80)}$

Symptoms caused by the narrow-leaved milkweeds usually appear about 14 hours after eating the plants. The animals become weak, wobble, and stagger about. The pulse is high and rather weak. In mild cases of poisoning these may be the only symptoms noticed. In more severe cases 
this period of weakness is followed by the loss of all control over the muscles of the legs, so that the animal falls down. Spasms follow at short intervals in which the legs are extended rigidly. Often grating of the teeth and champing of the jaws and other convulsive movements are noticed. Attacks may last for 24 hours, during which time the temperature rises, having been known to reach a maximum of $106.4^{\circ} \mathrm{F}$. Two of the fatal cases deseribed by Marsh ${ }^{(80)}$ were salivated and one was bloated.

Preventive Measures.-There is no known successful way of treating milkweed poisoning except by prevention. Milkweeds when green are distasteful to animals so they do not eat them unless starved or unless other forage is not available. Eradication is almost impossible because of the spreading, horizontal roots, from which new plants arise by budding from very small pieces. Prevention through a supply of abundant food is the only means of coping with these plants.

\section{LAURELS, AZALEAS, AND OTHER HEATHS}

Various members of the heath family (Ericaceae) are very poisonous to livestock. Sheep and goats, because of their browsing habits, are particularly subject to heavy annual losses in California and the northwest. Cattle suffer little since they browse upon heath plants only under unusual range conditions.

Seven species of the heath family have been found to be poisonous to livestock in California. While some of these grow in restricted and inaccessible areas, others are widespread, which cause stock owners much anxiety. The troublesome species are: black laurel (Leucothoë davisiae Torr.), western azalea (Rhododendron occidentale Gray), California rose bay (Rhododendron californicum Hook.), pale laurel (Kalmia polifolia Wang.), Labrador tea (Ledum glandulosum Nutt.), rustyleaf (Menziesia ferruginea Sm.), and Indian pipe (monotropa uniflora L.).

Black laurel is one of the most poisonous species of the heath family. Marsh ${ }^{(78)}$ has shown that 1 to 2 ounces of the leaves will kill a sheep. It is a glabrous evergreen shrub, 2 to 5 feet high, with alternate, leathery, oblong leaves. The flowers are wax-like, drooping, and clustered in terminal racemes. Flowering occurs from June to September, but the flowers persist for a year or more after withering (plate $3 A$ ).

This shrub is widely distributed and common in parts of the Sierra Nevada as well as in the north Coast ranges (fig. 9). It grows in damp meadows or in open pine forests, between 5,000 and 8,000 feet in the Sierra Nevada, and from 4,000 to 5,000 feet in the coastal mountains. It is often associated with spiraea and lodgepole pine.

Western azalea, though not so toxic as black laurel, is so common as to make it very important as a poisonous plant. It is a deciduous shrub, 
3 to 14 feet high, with alternate, thin, entire leaves, 1 to 4 inches long. The large flowers are pink or white, $1 \frac{1}{2}$ to 3 inches long, borne in terminal clusters, with the style and the fine stamens extending well beyond the corolla. The flowering period is from May to August (plate $3 B$ ). It

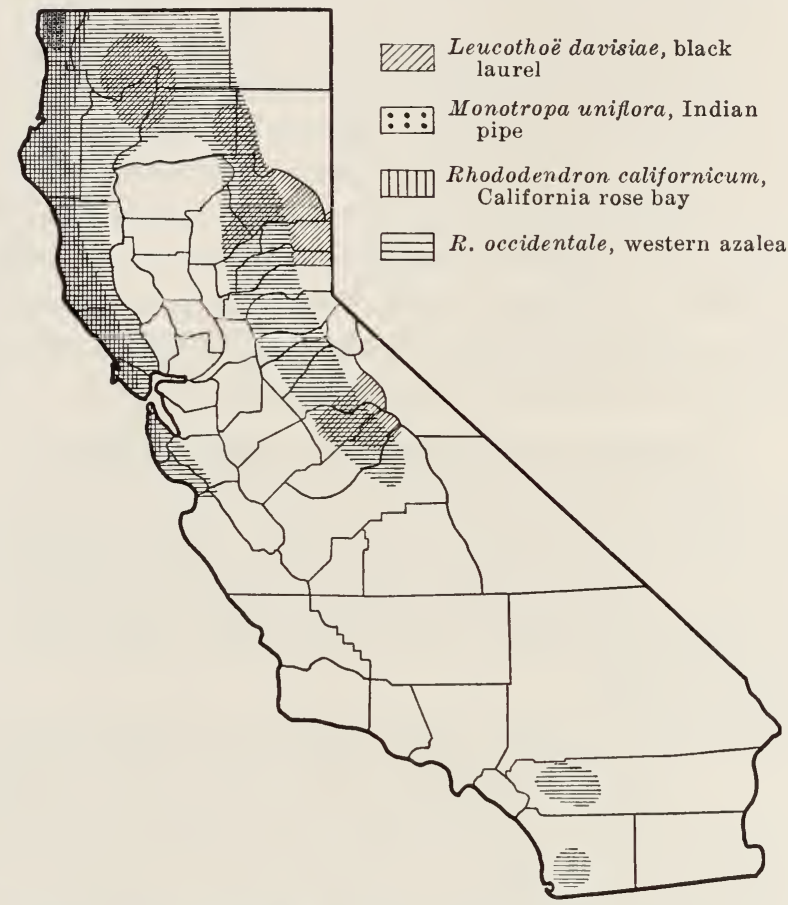

Fig. 9.-Distribution of black laurel, Indian pipe, California rose bay, and western azalea.

occurs in various parts of the Sierra Nevada between elevations of 3,500 to 7,500 feet and in the Coast Range from sea level upward (fig. 9).

Western azalea is purely riparian in habitat, growing in wooded districts along stream banks, or in wet and seepy places, seldom on open slopes. In Humboldt County it is often found in soils of serpentine formation. Characteristic associates are willows, alders, creek dogwood, and California bay. It is much dreaded by sheep owners. Both Chestnut ${ }^{(18)}$ and Marsh ${ }^{(78)}$ have reported that the annual losses in sheep are heavy where these animals are pastured on badly infested areas for considerable periods of time.

California rose bay resembles western azalea, except for the flowers, which are deep rose-purple, and the leaves which are leathery and evergreen, rather than deciduous. As a shrub or a small tree, it grows from 3 to 26 feet high. The flowering period is from March to July. Distinctly 
a coast species, it ranges from San Mateo and Marin counties northward to Washington, being especially abundant along the Mendocino coast where it is the common brush plant in forested areas (fig. 9). Unlike western azalea, this species is not found in wooded stream banks, but is

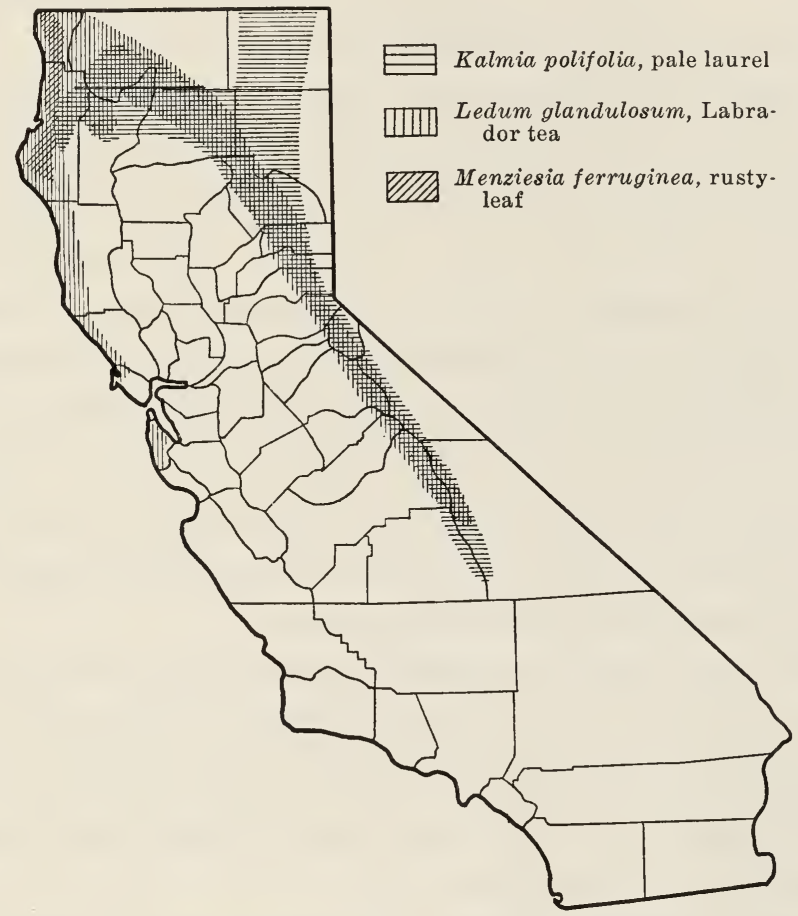

Fig. 10.-Distribution of the pale laurel, Labrador tea, and rustyleaf.

found on the open slopes, from sea level to 5,000 feet in elevation. Common associates are redwood, manzanita, wax myrtle (Myrica), salal (Gaultheria), huckleberry, and golden cup oak.

California rose bay has long been considered poisonous to sheep. Chestnut ${ }^{(18)}$ states that it is probable that the leaves contain andromedotoxin, the characteristic poisonous substance of the heath.

Pale laurel, sometimes called swamp laurel, and the variety microphylla Rehd., known as alpine laurel, have been reported by some workers to be the most poisonous plants of the heath family. Fortunately, owing to their habitat, they are seldom encountered by livestock. Pale laurel is a stunted evergreen shrub, 1 to 2 feet high, having opposite, leathery leaves with rolled margins, deep green above, pale beneatl. The lilac-purple flowers are saucer-shaped, borne in terminal umbels, 
each flower on a slender pedicel. The flowering period is from June to August (plate $3 C$ ).

Pale laurel occurs the entire length of the Sierras, to Trinity County and partly into Humboldt County (fig. 10). Its elevational range is from 7,000 feet to the summits of the higher mountains, where it is confined largely to the edges of wet meadows or swamps.

Alpine laurel is a high-mountain dwarf shrub, growing at or near timberline, in cold wet meadows, swamps, bogs, or marshes. It is found from 6,500 to 12,000 feet in the Sierra Nevada and as low as 3,500 feet in Humboldt County. Associates with alpine laurel are Labrador tea, white bark pine, lodgepole pine, mountain hemlock, western juniper, granite gilia, elderberry, and the huckleberry. Clawson ${ }^{(24)}$ states that as little as 0.3 per cent of the weight of a sheep of the green leaves causes illness, and that this plant may at times poison sheep, goats, and cattle.

Few animals graze upon the more rugged elevated ranges occupied by pale laurel and alpine laurel, so that although troublesome, they are not as important as their extremely toxic nature might indicate. In some sections, however, pale laurel has been very destructive to sheep. It may also be poisonous to goats and other livestock.

Labrador tea is often erroneously called black laurel, although its appearance is different from it. Like black laurel, it is an evergreen shrub with thick leaves. These are resin-dotted beneath, making the herbage very fragrant when bruised. The flowers are yellowish white, not clear waxy white, and are borne in terminal umbrella-like clusters rather than in long racemes as in black laurel.

In the Sierra Nevada it has much the same range as pale laurel, although it does not grow at quite as high altitudes. In Tulare, Shasta, and Siskiyou counties it is found from 3,800 to 10,000 feet, while in the coast ranges it grows from sea level to 500 feet in elevation (fig. 10).

The favorite habitats are along stream and lake banks or borders of wet meadows. It is often found with the same associates as pale laurel, but more characteristically with honeysuckle, monkshood, red heather, mountain willow, silver pine, and red fir. Although this plant has been considered as poisonous as black laurel, Marsh ${ }^{(78)}$ has shown that it is only slightly toxic. Since it probably seldom causes livestock losses under range conditions, it is important that this plant be distinguished from the other species of heaths.

Rustyleaf is a deciduous shrub 3 to 15 feet high, with thin, alternate leaves bearing scattered rusty hairs on the upper surface. The flowers are greenish purple, on long slender pedicels and borne in terminal clusters. The flowering period is in May and June (plate $3 \mathrm{D}$ ). 
In California, rustyleaf is known only from Humboldt County northward, its northern limit being Alaska (fig. 10). It grows in dense forests along streams, from sea level to 6,000 feet elevation. Since a considerable quantity must be eaten before symptoms appear, ${ }^{(78)}$ and since the species is limited in California, rustyleaf is not a serious factor.

Indian pipe is a glabrous, waxy-white herb only 4 to 7 inches high, with scaly stems but no true leaves. It turns black when picked. In California it is found only in damp dark woods in Del Norte County (fig. 9). Although it has been found to contain the poison andromedotoxin, ${ }^{(31)}$ its limited distribution and unfavorable grazing habitat makes it of little importance in this state.

Since heath plants are generally low in palatability they are eaten only when abundant, and when wholesome forage is not available. Various investigations have reported that sheep suffer most from browsing upon them, a conclusion substantiated by one of the writer's observations in California.

The symptoms produced by the species here discussed are practically identical. Commonly there is salivation or frothing at the mouth, conspicuous secretion from the nose, nausea, vomiting, followed by depression and weakness resulting in a staggering gait, and later, paralysis of the limbs. Often there is irregular respiration. ${ }^{(74)}$

Although prevention, by keeping the animals away from infested areas, is the most practicable method of control, remedial measures may sometimes be worthy of trial. Epsom salts dissolved in water as a drench, given in doses from 2 to 6 ounces, aids in eliminating the poison. ${ }^{(51)}$ The use of lard has also been suggested. No specific remedial agent is known.

\section{WILD TOBACCOS}

Several genera of the nightshade or potato family (Solanaceae) include species poisonous to livestock; but the plants which cause most of the trouble on the ranges of California are the wild tobaccos, genus Nicotiana.

Description and Distribution.-Tobaccos are strongly scented plants, with a sticky-hairy surface, and leaves with smooth (entire) margins. The flowers, borne in panicles or racemes, are characterized by a 5 -toothed or 5-lobed calyx and a funnel-shaped corolla. The fruit is a smooth 2-celled capsule bearing numerous small seeds (fig. 11).

One or more of the five species of tobacco occuring in California is found in scattered stands at medium to low elevations almost throughout the state. They typically occupy waste places, flood beds, and frequently invade burned-over chaparral areas. 
Presumably all species of tobacco are poisonous, yet only three appear to have caused sickness among livestock in California. They are desert tobacco (Nicotiana trigonophylla Dunal.), coyote tobacco (N. attenuata Torr.), and tree tobacco ( $N$. glauca Graham).

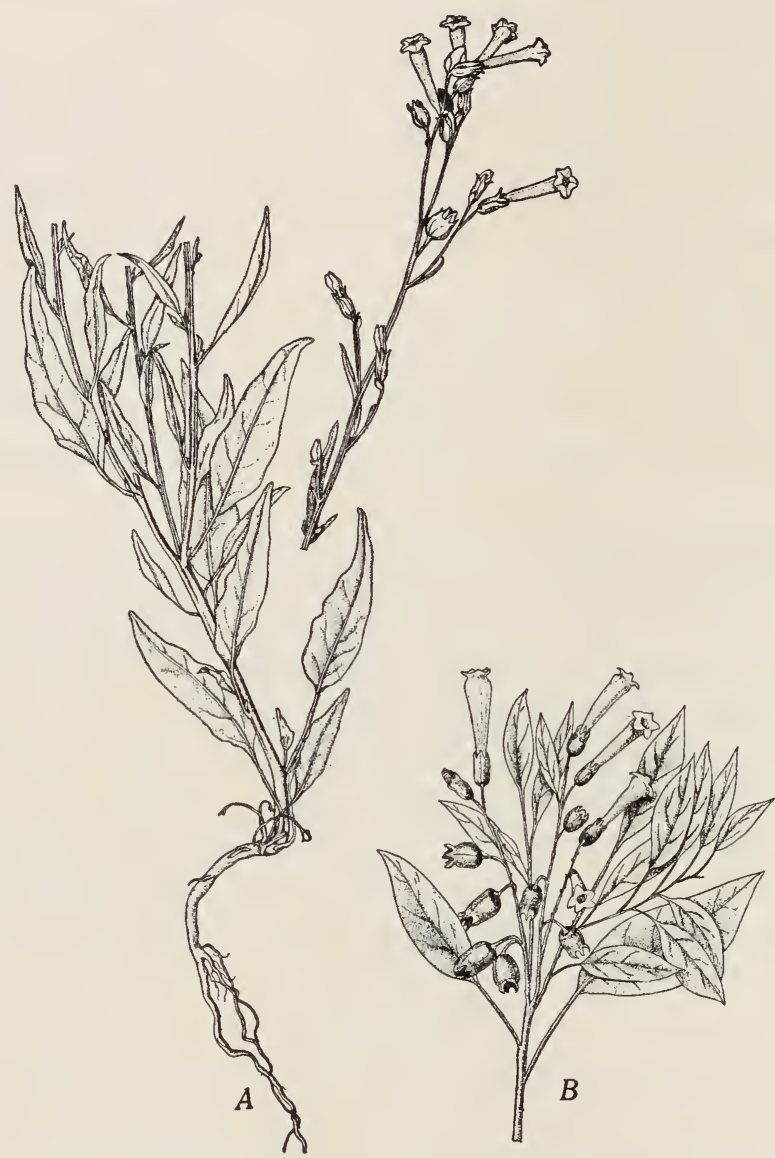

Fig. 11.-Wild tobaccos: $A$, coyote tobacco (Nicotiana attenuata) $; B$, tree tobacco (Nicotiana glauca).

Desert tobacco is a slender, sticky-haired annual, 1 to 3 feet high, with leaves 2 to 5 inches long, the upper sessile, the lower with a short-winged petiole. The flowers, which open during the day, are cream or greenish white, borne in nearly leafless racemes. The calyx is about one-half as long as the flower tube. Filaments are hairy at the very base and attached at the middle of the corolla tube. The plant begins flowering in December, seldom continuing later than May.

In California this tobacco is limited to the Colorado and Mojave deserts (fig. 12), where it occupies sandy, rocky soil of canyon springs, crevices 


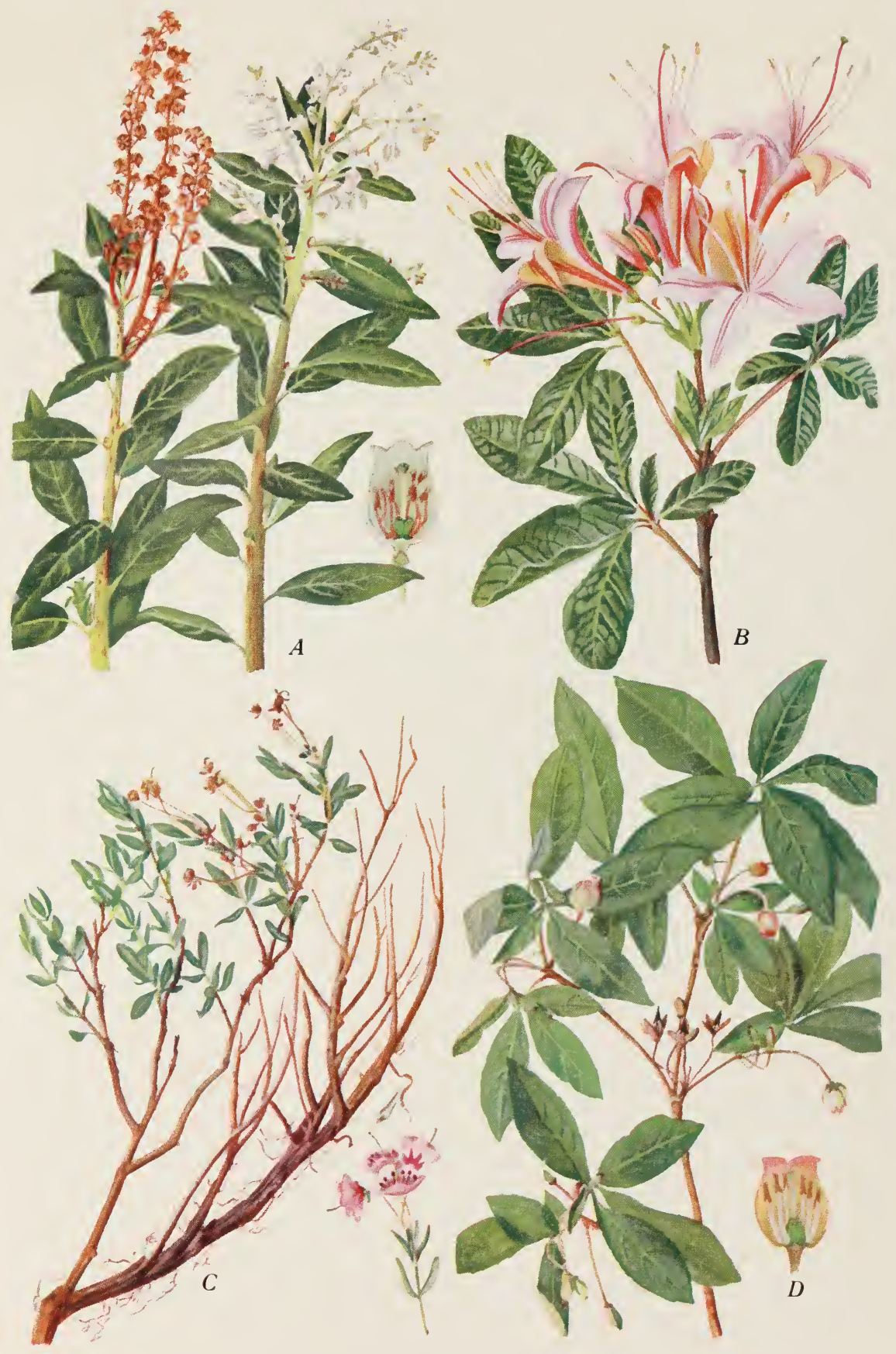

Plate 3.-A, Black laurel (Leucothö̈ davisiae); $B$, western azalea (Rhododendron occiden tale); $C$, pale laurel (Kalmia polifolia); $D$, rustyleaf (Menziesia ferruginea). 

of cliffs, and hillsides between elevations of 100 and 7,500 feet. The individual plants are usually scattered. Commonly desert tobacco is associated with Joshua tree, giant eactus, and both honey and screw-bean mesquites.

Coyote tobacco is similar in appearance to desert tobaceo, but differs in that the flowers, growing along leafy racemes on much-branched

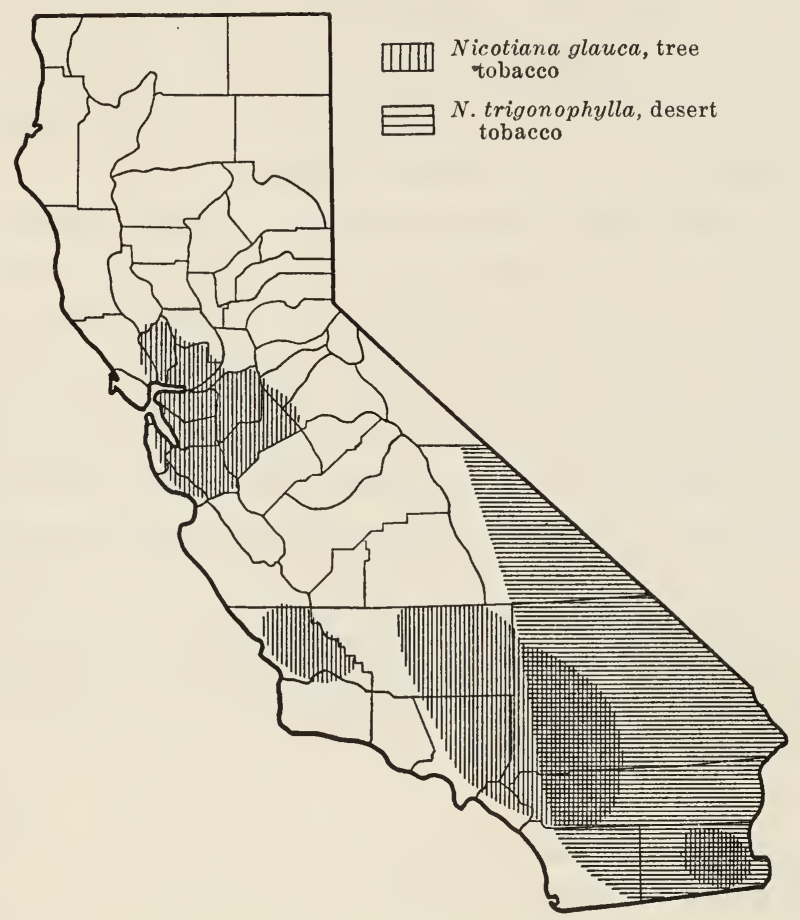

Fig. 12.-Distribution of tree tobacco and desert tobacco.

stems, are more numerous. Also, they open only at night. The calyx teeth are only one-third as long as the flower tube. None of the leaves are auriculate clasping as with desert tobacco, but all are petioled (fig. $11 \mathrm{~A}$ ). The flowering period is from April to November.

This species is somewhat common throughout most of the state, being found along the borders of the Mojave and Colorado deserts to Humboldt, Siskiyou, and Modoc counties. It is rare in coastal counties and is most abundant in the interior, occupying flats and valley floors, adobe meadows, and dry sandy loam under mesquite shrubs. In altitude it ranges from 100 to 4,000 feet in the deserts, going up to 8,000 feet or more in the high mountains, where it occupies gravelly slopes. On Mt. Whitney it has been collected at an elevation of 10,000 feet. 
Tree tobaceo is strikingly different from the two species described. It is a glaucous, evergreen shrub or small tree, 2 to 18 feet high, with leaves often 12 inches long. The stems are pithy and the flowers are greenish yellow (fig. $11 \mathrm{~B}$ ). The flowers appear from December to April.

This plant was introduced from South America. Although essentially a southern-California species, it is found as far north as Napa County (fig. 12), and is much more common in the state than the distribution map would indicate. Single specimens are rather commonly seen along roadsides, flood beds of creeks and streams, waste places, and around dwellings. In Santa Cruz County it is found in gulches below the redwood. The range in elevation is 100 to 3,000 feet.

Nature of Injury and Animals Affected.-Experiments have shown that coyote tobacco is somewhat less toxic than desert tobacco, although the symptoms and toxic dosage differ only slightly. That tree tobaceo is poisonous is not doubted. Serious losses of cattle from feeding on the leaves and young stems of this plant have been reported from San Luis Obispo County. In Australia it is reported to affect horses, but in California no such injury has been reported under range conditions. Cattle, sheep, horses, and chickens have been used in investigating its toxicity and all are affected. ${ }^{(98)}$ Cattle and horses were found to be poisoned more often than sheep. In all these species all parts of the plants were found poisonous, but there was some indication that the stems were more toxic than the leaves. The toxic and the lethal doses for the animals fed on two of the tobaccos were as follows :

\begin{tabular}{|c|c|c|c|}
\hline Animal & Ani & $\begin{array}{l}\text { oxic Dose } \\
\text { er Cent of } \\
\text { nal's Weight }\end{array}$ & $\begin{array}{l}\text { Lethal Dose, } \\
\text { Per Cent of } \\
\text { Animal's Weight }\end{array}$ \\
\hline Sheep & Desert toboceo. & 1.42 & 3.25 \\
\hline Cattle & Desert tobacco............... & 0.5 & 2.0 \\
\hline Horses & Desert tobacco.......... & 0.68 & $\ldots .$. \\
\hline Sheep & Coyote tobacco & 2.5 & 3.6 \\
\hline
\end{tabular}

The symptoms of poisoning from the species fed have been reported to be practically alike, appearing in from 30 to 43 minutes, or sometimes almost immediately after eating the plant. The pulse is weak, the eyes are staring. There is unsteadiness, wobbling from side to side, stiff-leggedness, stumbling, and trembling of the whole body. The animal is finally forced to lie down. Salivation and frequent urination are characteristic. The weakness increases and breathing becomes heavier and more difficult until death supervenes. ${ }^{(98)}$

Preventive Measures.-Poisoned animals should be kept quiet and if there is a tendency to constipation, a laxative, like linseed oil, should prove helpful. ${ }^{(98)}$ Since desert tobacco and coyote tobacco are annuals and can sometimes conveniently be cut before seed maturity, this should 
- be done to prevent their spread. Often they occur in rather isolated patches, hence it is not difficult to prevent animals from having access to them.

\section{BRACKEN FERN}

Bracken fern, a member of the fern family (Polypodiaceae), is also called brake, lady-bracken, fern bracken, and hog bracken. Because of various reported instances of the poisoning of animals by bracken fern in New York State, in Oregon, and in Europe, it is probable that more cattle are lost in California by feeding upon this plant than is generally supposed. Because of the ever-increasing reports and findings, substantiating its toxic characteristics, and the fact that the plant occupies such extensive areas in the state, it is included in the list of primary poisonous species.

Description and Distribution.-Bracken fern, Pteris aquilina L. var. lanuginosa (Bory) Hook., is a coarse plant, having a creeping, woody, almost black rootstock. All of the plant aboveground appears as one large, much-divided leaf or frond, with a central stalk. This frond is 1 to 4 feet high and 1 to 3 feet across. On the under side of this leaf are overturned margins under which are many tiny rust-colored spore cases, or fruiting bodies.

Bracken is common throughout the state in the foothills, and abundant in our mountains in the ponderosa-pine belt. Often it densely covers whole hillsides and valley bottoms, growing in moderately moist soil, in shade, or in full sunlight up to 7,000 feet in elevation in the interior mountains.

Nature of Injury and Animals Affected.-Experiments show that the poisoning of animals is due to the eating of the leaves and not the spores, as had been popularly believed. ${ }^{(110)}$ The plant is equally poisonous in the green and dry state at all times of the year. ${ }^{(13)}$ The palatability of the plant varies widely for different animals. The writers have observed deer, for instance, feeding ravenously on the fronds, evidently with no ill effects. Domestic livestock, on the other hand, seldom devour the green plant in quantity unless starving, or only when held on very inferior forage, hence poisoning by the green plants has generally been regarded as somewhat exceptional. ${ }^{(13)}$ However, Dr. A. B. Clawson, Physiologist, in charge of Poison Plant Investigations, U. S. Department of Agriculture, in correspondence with the writers under date of August 10, 1934, stated that the effect of the fern on cattle in many localities of the West has been wrongly diagnosed as hemorrhagic septicemia, and that he suspects the same mistake may have been made in the Pacific Northwest, and perhaps in California. Dr. Clawson's letter further states: 
"In New York State a considerable number of cattle have been poisoned on overgrazed pastures and the symptoms seen in the animals have been produced experimentally by feeding the fern. Similar evidence (of its toxicity) has been produced in England and France."

Although poisoning of cattle has been most generally reported, sheep and horses are susceptible to the disease. Horses suffer from what has been termed "fern staggers." Quoting again from Clawson: "In sections where this fern is abundant enough to be plentiful in hay, it is responsible for heavier losses among horses than any other plant." So far as known, disastrous losses of horses are not common in California.

In cattle, Dr. A. B. Clawson has pointed out, the more conspicuous symptoms are high body temperature, bloody discharges from the mouth, nostrils, and alimentary tract.

The first symptom noticed in horses is uncertain gait. The eyes are dilated, the head is usually carried low, and the animal often pushes or batters objects with the head. Twitching of the muscles, especially of the face, is characteristic. The appetite remains good and the temperature is normal. The animal gradually becomes weaker and finally goes down, but usually not until 7 to 20 days after the appearance of the first symptoms. Death usually follows a few days after the strength begins to wane.

The poison is cumulative. Hay which contains about one-third of the common bracken fern by weight is dangerous. Approximately 6 pounds of cured fern in the daily diet has been reported to kill a horse in four or five weeks. ${ }^{(110)}$

Preventive Measures.-When the symptoms are first noted a veterinarian should be called. If that is impossible the animal should be placed in shade and given a purgative, such as a quart of raw linseed oil. Dr. Robert Jay, United States Department of Agriculture, has reported to the writers by letter that an investigation of the poisonous properties of the bracken fern, conducted at the Oregon State College, Corvallis, under the direction of Dr. B. T. Simms, indicates strongly that the exposure of animals to the sun after feeding generously upon this plant results in death. Dr. Jay recommends, on the basis of considerable experimental evidence, that affected animals be removed immediately to a shady place. He states that affected animals should not be permitted to graze in the open between the hours of about 9 a.m. and 5 p.m. During the period of recovery, good clean hay, warm bran mash, and roots, such as carrots, may be given; and care should be taken that the animal is not exposed to inclement weather. ${ }^{(48,110)}$ 
Where the land is suitable, plowing and manuring will result in eradication of bracken fern; after two or three years of such treatment the plant is usually eliminated. On hilly pastures, where cultivation is not possible, the present writers have found that cutting the green tops early in the season close to the ground about three times in a season will usually kill the plant at the end of the third year. In northern California, where growth conditions are favorable, revegetation of the pasture to vigorously growing grasses has been found fairly effective in replacing the fern.

\section{POISONOUS PLANTS OF SECONDARY IMPORTANCE}

There is not sufficient information available to list the plants of this group according to the livestock losses caused by them. Those of the true flowering plants are arranged according to their botanical classification, ${ }^{(69)}$ beginning with the arrow-grass family. The ferns, horsetails, and poisonous mushrooms are briefly discussed at the end of this grouping.

\section{ARROW-GRASS}

Goose-grass and sour grass are other popular names for arrow-grass, a member of the arrow-grass family (Juncaginaceae).

Description and Distribution.-Arrow-grass, Triglochin maritima L., is an erect perennial grass-like herb, 6 inches to $2 \frac{1}{2}$ feet high, arising from a base covered with sheaths of old leaves. It grows in scattered clumps about 12 inches wide or in patches 10 to 20 feet or more across. The fleshy, bright-green leaves are shorter than the flowering stalks. The scapes or flowering stems are stout, terminating in racemes 10 to 15 inches long, bearing inconspicuous greenish flowers (fig. $13 \mathrm{~A}$ ). The three-sided fruits are about $1 / 4$ inch long. April to July is the flowering period. This plant may be distinguished from ordinary grasses by the fact that the leaves are not thin, flat, or folded like grass blades, but are thick and spongy and semicircular in cross section. The leaves of sedges, in contrast, are usually definitely triangular and often folded.

Arrow-grass occurs in rather well-defined areas in the interior, and over a large range in northeastern California, and along the coast from the Bay region southwest (fig. 14).

Arrow-grass undoubtedly causes considerable losses of cattle and some sheep each year. Probably many cases have been attributed to other plants, as arrow-grass is not generally recognized by stockmen as poisonous.

The symptoms produced are typical of prussic acid poisoning, as shown in abnormal, rapid breathing, and rapid pulse. In severe cases 

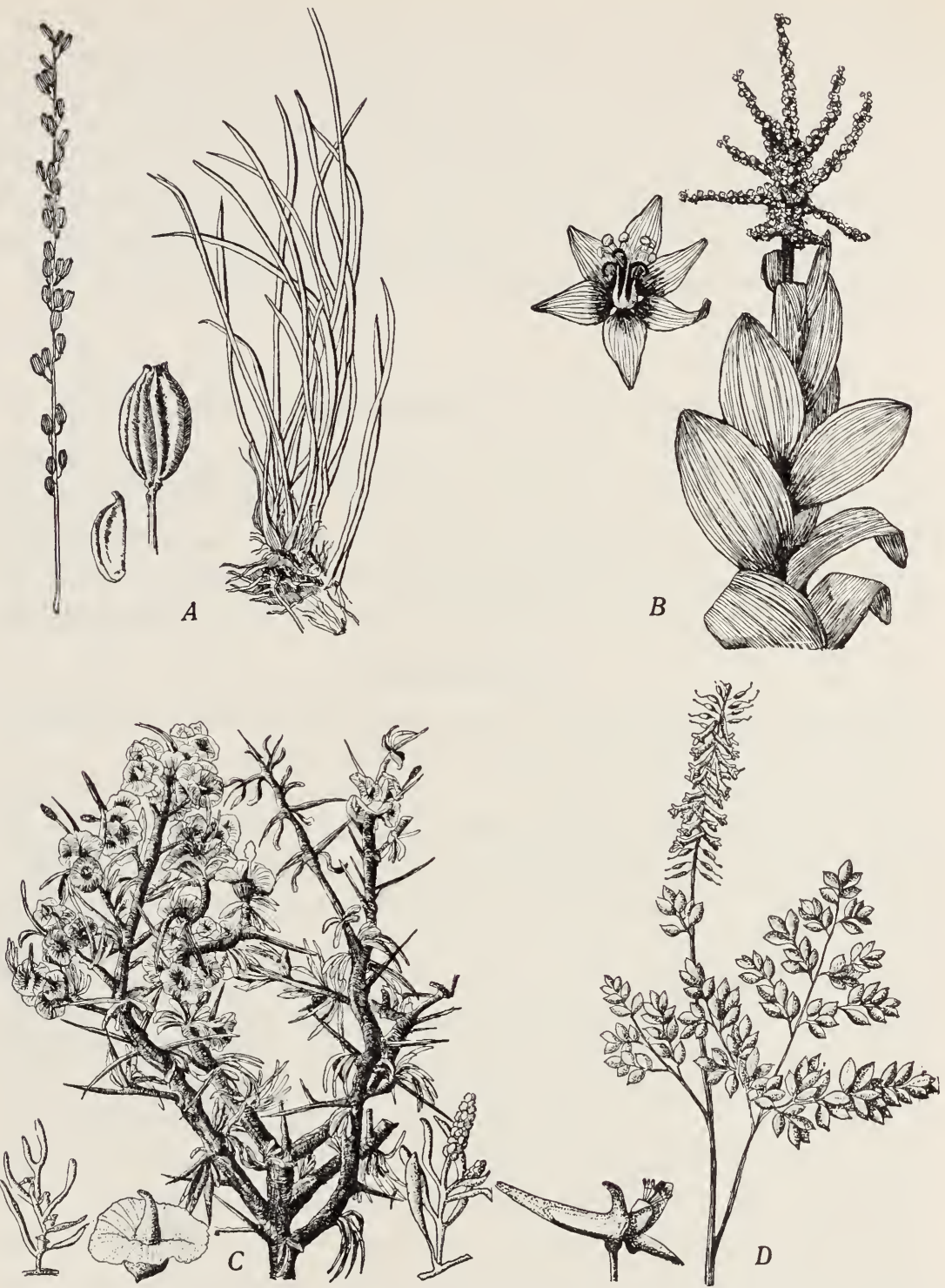

Fig. 13.-A, Arrow-grass (Triglochin maritima) ; $B$, California false hellebore (Veratrum californicum); C, black greasewood (Sarcobatus vermiculatus); and $D$, fitweed (Corydalis caseana).

the animal trembles, staggers, or walks stiffly, has spasms, and finally goes down in convulsions. Towards the end, breathing becomes very difficult and noisy, spasms continuing at intervals until death. Death is the result of respiratory paralysis. 
The minimum toxic and the lethal doses for sheep are approximately 1 and 2 per cent of the animal's weight, respectively; for cattle the minimum toxic dose is less than 1 per cent of the animal's weight, and the lethal dose is 1.7 per cent. If poisoning occurs the toxic dose has been

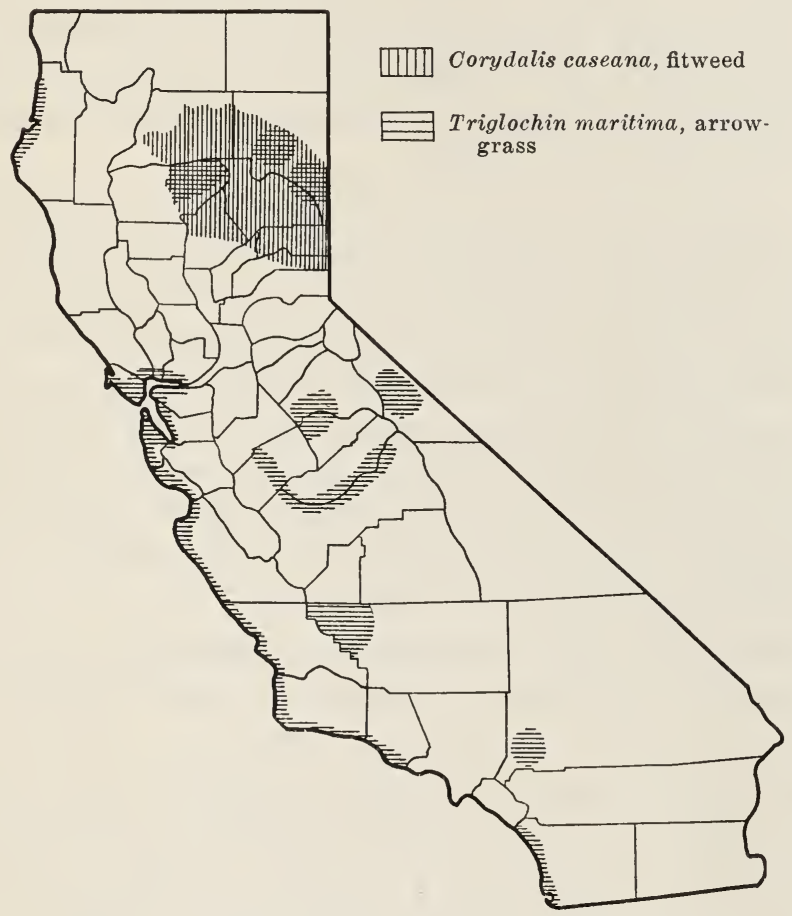

Fig. 14.-Distribution of fitweed and arrow-grass.

eaten within a very short period as the poison is not cumulative, nor is the sickness of long duration. The animal either dies or recovers within ten hours at the most, but usually within an hour.

The poison acts so quickly that little reliance can be placed on medicinal aid. However, a number of remedies have been suggested to be administered under the direction of a veterinarian. Among them are hydrogen peroxide, potassium permanganate, cobalt nitrate, and glucose. Atropine may be given to stimulate respiration. ${ }^{(100)}$ (See also treatment for sorghum poisoning.)

Prevention.-If wet meadows, which are favorite habitats of arrowgrass, are badly infested with this weed, they should either not be used for pasture or the portions most heavily infested should be fenced against livestock. Such measures are particularly necessary in this instance, for arrow-grass is very palatable, the animals often eating the plant in preference to wholesome forage. 


\section{THE SORGHUMS}

Although grasses are generally wholesome and are the most important of all range plants, a few are poisonous at certain stages of their growth. Those most likely to cause trouble to pasture livestock are the sorghums, notably Johnson grass (Holcus halepensis L.) and Sudan grass (H. sorghum var. sudanensis (Piper) Hitche.). Certain other species and varieties of the sorghum tribe have also proved poisonous under unusual conditions of growth or treatment.

Nature of Injury and Animals Affected.-The harmful substance in sorghum grasses, when poisonous, is hydrocyanic or prussic acid. All parts of the plants may be poisonous, the entire young plants being more toxic than entire mature ones, and the young leaves being more toxic than the young stems. The percentage of hydrocyanic acid decreases steadily from the time the plants begin to grow until the seed begins to ripen, at which time there is so little that livestock are not affected. In some cases, when growth has been interrupted, such as by frost, and especially by drought, there has been noted an actual increase in the poison. Dry or cured sorghums are rarely if ever toxic. ${ }^{(114)}$

Cattle, sheep, and goats are affected. ${ }^{(16)}$ Death may ensue within a few minutes after a lethal dose is eaten, but if a lethal dose is not taken the animal merely suffers acutely for a short time.

Remedial and Preventive Measures.-Glucose, dextrose, and certain other forms of sugars have been used with some success as antidotes for this poison. More recently sodium nitrate and sodium thiosulfate, injected intravenously, have been reported to the writers by Dr. A. B. Clawson, as being effective antidotes. Haring, ${ }^{(62)}$ on the other hand, recommends the following treatment for hydrocyanic acid poisoning of livestock:

Bottle No. 1.-Select a quart bottle with a long neck and place in it one pint of water and 1 ounce of sodium carbonate (baking soda).

Bottle No. 2.-Place in this bottle $1 / 2$ ounce of iron sulfate (copperas) dissolved in a pint of water. Keep the bottles tightly corked.

When needed, pour the contents of bottle No. 2 into bottle No. 1 , shake, and administer in a drench immediately. A cow should receive a quart, and a sheep $1 / 2$ pint of the mixture. This preparation can be made up in larger quantities, if desired, so that several animals may be treated. Any remedy to be effective must be available for immediate use. This remedy is also effective. for poisoning by chokecherry (Prunus demissa), or by arrow-grass (Triglochin maritima). Poisoning by Johnson grass is common in the East and in several western states. If the 
extent to which it causes poisoning in California were known, it might conceivably be placed in the list of "primary importance."

\section{FALSE HELLEBORES}

The false hellebores, genus Veratrum, are liliaceous plants and are known by various popular names, notably cow cabbage, corn lily, wild Indian corn, Indian poke, and devil's bit. They are sometimes called skunk cabbage, the well-established common name for an entirely different plant.

Description and Distribution.-The tall, leafy stems of the false hellebores arise from stout rootstocks having coarse, fibrous roots. The leaves are broad, without petioles, somewhat folded (plicate), and coarsely nerved. The flowers are in panicles, the upper flowers perfect and the lower ones staminate. In the perfect flowers there are 3 petals, 3 sepals, and 6 stamens. The fruit is a many-seeded capsule, the seeds being flat with broad wings. Jepson ${ }^{(69)}$ lists four species in California. The first of these, California false hellebore, Veratrum californicum Durand. (fig. $13 \mathrm{~B}$ ) is the most widespread species in the state. It is a stout perennial, 2 to 8 feet high, the stems resembling those of a cornstalk, and bearing leaves sometimes a foot long. The greenish-yellow flowers are borne in panicles 1 to $1 \frac{1}{2}$ feet long. The flowering period is from June to July.

California false hellebore is common throughout the Sierra Nevada between elevations of 4,500 and 9,000 feet, and also in the north Coast ranges down to sea level (fig. 15). It grows in dense stands around springs, in marshy flats, meadows, swamps, and bogs. Frequently it is associated with Sierra shooting star (Dodecatheon), meadow lotus, and Bigelow sneezeweed.

The three other Californian false hellebores are almost identical in appearance to California false hellebore, but all have a limited distribution. Veratrum viride Ait., which is the common species in states north to Alaska, is confined to northern California (fig. 15). V. fimbriatum Gray, a coast species (fig. 15), is often found in chaparral. V. insolitum Jepson, also found only in the northern part of the state, inhabits brush fields (fig. 15).

Nature of Injury and Animals Affected.-The bulbs are probably the most poisonous, although this fact has not been definitely proved. The whole plant is known to be more or less toxic. Several poisonous alkaloids have been found, of which veratrin is probably the best known. It produces violent sneezing, and dilation of the pupils. A glucoside also has been found called veratomarin, which is a powerful depressant to the heart muscles and vasomotor centers. 
Although the false hellebores are not violently poisonous, they are known to have caused illness in sheep at certain seasons, and it is possible that they may poison other grazing animals as well. Chestnut ${ }^{(21)}$ states that all false hellebores are poisonous if eaten in considerable amounts.

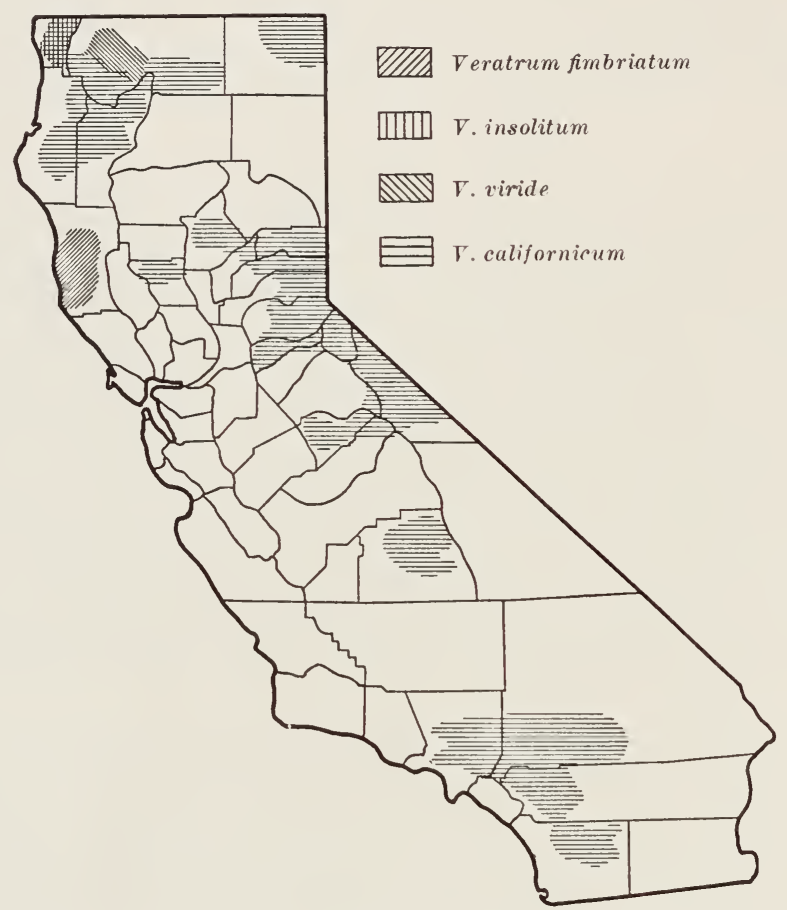

Fig. 15.-Distribution of the four species of false hellebore.

Poisoned animals are salivated. They often vomit, show muscular weakness, tremors, and spasms. The breathing is hollow, and the temperature is reduced. Temporary blindness often follows. ${ }^{(46)}$ Death results from paralysis of the heart. ${ }^{(60)}$

Keeping the animals away from the larger patches is the best means of avoiding losses.

\section{BLACK GREASEWOOD}

Black greasewood, Sarcobatus vermiculatus (Hook.) Torr., the only species of the genus, is a member of the beet family (Chenopodiaceae), to which belong many valuable forage plants. It is also called chico, and merely greasewood.

Description and Distribution.-Black greasewood is a shrub 2 to 6 feet high, with stiff, closely interlocking spiny branches, with white bark. The leaves are alternate, narrow, and fleshy, $1 / 2$ to 2 inches long, flat on 
the upper side and rounded beneath. The greenish flowers are small and inconspicuous, giving rise to cone-shaped fruiting spikes $1 / 2$ inch long. The foliage is at first a clear dark green in color, but later becomes reddish. In autumn, after the leaves have fallen, the spines of the branches are conspicuous (fig. $13 C$ ).

In California, black greasewood is found in the Colorado and Mojave deserts, and from Inyo to Lassen and Modoc counties. It is common on alkaline clay soil of desert valleys or flats, often associated with yellowbrush (Chrysothamnus), saltbush, and shadscale (Atriplex).

Animals Affected.-Black greasewood is known to poison cattle. Experimental feedings ${ }^{(40,89)}$ however, have proved that it is most poisonous to sheep. In Utah, for example, sheep are almost always the animals poisoned, and the losses are rather common. On range areas where black greasewood is very dense and there is a shortage of other feed, often whole bands, or many animals in a band, instead of scattered individuals, are poisoned at one time, making the total number of annual losses rather heavy in California and adjacent states. Poisoning is due to the presence of oxalates of sodium and potassium in the plant. Quoting from Couch: "Large quantities of potassium and sodium oxalates were found, and these are responsible for the cases of range poisoning." ${ }^{(25)}$ Young stems and fresh leaves are the most poisonous, but the entire plant contains the toxic material. Accordingly the most dangerous season is in early spring, little trouble having occurred in fall and winter when it is regarded as a valuable browse plant on many arid, semiarid, and alkaline lands. ${ }^{(32)}$

Plant material to the amount of 1.5 to 5.0 per cent of the animal's weight, taken within about an hour, has produced illness or death. Poisoned animals in most cases die. Symptoms, which appear in 3 to 4 hours after the toxic or fatal dose is eaten, are very distinctive. There is an initial period of drowsiness, during which the animal stands or walks listlessly. Finally it lies down from weakness. Gradually the depression becomes more pronounced, the pulse weakens, and a state of profound prostration, with partial unconsciousness, develops. In this condition the animal may live for several hours before death ensues. Death usually occurs within 12 to 20 hours.

Preventive Measures.-The use of soluble salts of calcium ${ }^{\left({ }^{(8)}\right.}$ have proved of some remedial value. Poisoning by black greasewood may be avoided as long as the animals which have fed on this plant consume an abundance of other forage, and provided that large amounts of the poisonous plant are not taken in a short time. Herders should see to it that very hungry sheep are not allowed to graze exclusively on black greasewood, for under such conditions heavy losses are likely to occur. 


\section{MEXICAN TEA, WORMSEED, AND JERUSALEM TEA}

Mexican tea (Chenopodium ambrosioides L.), confined to southern California, wormseed (C. anthelminticum L.) of the Coast ranges and Sacramento Valley, and Jerusalem tea (C. botrys L.) of statewide distribution, contain poisonous volatile oils. ${ }^{(110)}$ These plants, like greasewood, are members of the beet family and are of no economic importance since animals strictly avoid them, except as they may occasionally encounter them in hay. ${ }^{(51)}$ They are found in California in waste places, near dwellings, and along roadsides, or in flood streams and salt marshes.

\section{FITWEED}

Fitweed, Corydalis caseana Gray, of the fumitory family (Fumariaceae), was first recognized as a poisonous range plant in 1929. ${ }^{(41)}$ Both cattle and sheep have died as a result of feeding upon this plant.

Description and Distribution.-Fitweed is a smooth-stemmed perennial arising from a thickened taproot and growing from $11 / 2$ to 3 feet high. The finely divided leaves are from $1 / 2$ to $11 / 4$ feet long and resemble those of the closely related common bleeding heart (Dicentra formosa). The flowers, borne in elongated clusters, are creamy-white with red or purplish tips, each with a single, nearly straight spur about $3 / 4$ inch long (fig. $13 \mathrm{D}$ ). The blossoming period is May to July.

The present known distribution of fitweed in California is confined to northeastern California (fig. 14), and ranges from 5,000 to 7,000 feet in elevation. It grows along margins of cold-water streams and lakes of well-drained mountain canyons, often with its roots in the water, being common in stony or gravelly soil. Frequently it grows in the shade of mountain alder, creek dogwood, and black cottonwood, in association with creek groundsel, and small tiger lily.

Nature of Injury and Animals Affected.-The poisonous substances present in fitweed are believed to be the same as those found in closely related species, which contain four alkaloids. The deadly alkaloid corydaline is present in abundance and may be the most toxic. It affects the nerve centers perceptibly. Evidently the entire plant is poisonous.

All domestic grazing animals are poisoned by fitweed, but cattle and sheep are affected most. Differing from most poisonous plants, fitweed is rather highly palatable and is eaten, especially by sheep, even when good feed is available. The fact, however, that the plant grows in moist areas, where livestock incline to congregate, and near their drinking places, may account for the relatively high palatability rating of this poisonous species. 


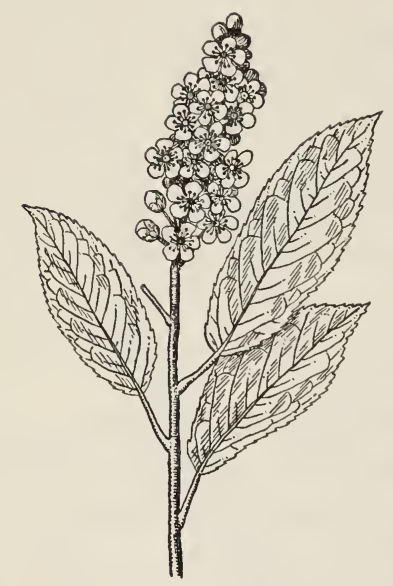

$A$

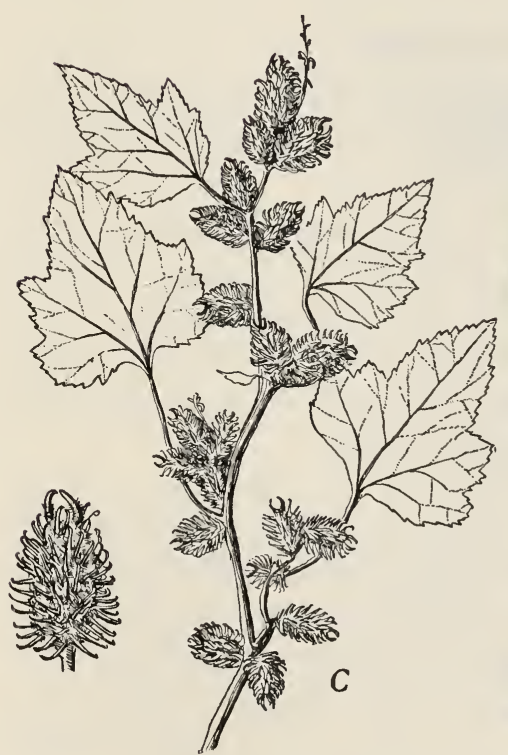

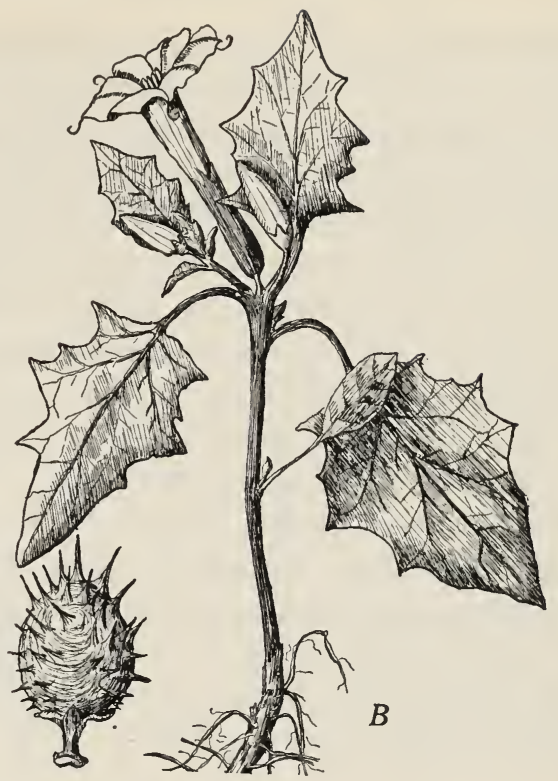

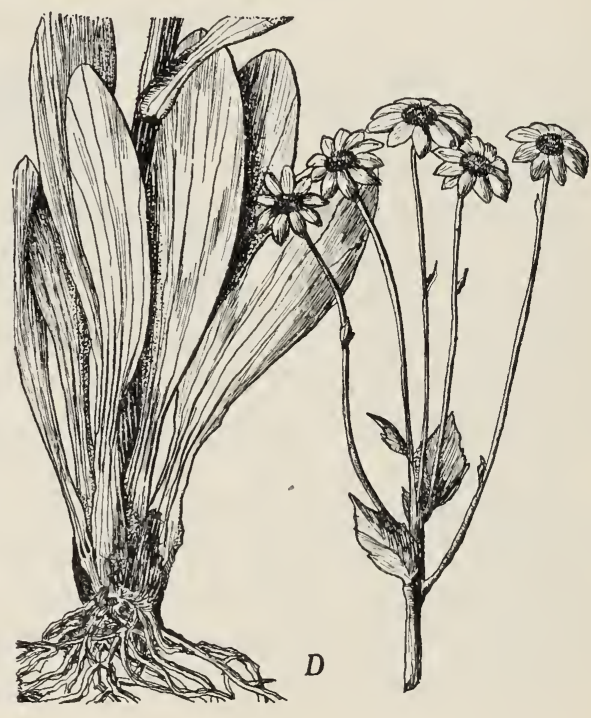

Fig. 16.-A, Western chokecherry (Prunus demissa); $B$, true Jimson weed ( $D a$ tura stramonium) ; $C$, cocklebur (Xanthium canadense); and $D$, western sneezeweed (Helenium hoopesii).

Because of the restricted distribution of fitweed and its scattered growth, except on certain overgrazed areas, the yearly livestock losses have not been very serious. Three adjacent ranges in the Plumas National Forest have suffered losses of 675 ewes in a period of eight years. ${ }^{(41)}$ 
The symptoms in sheep and cattle are very similar. Poisoned animals become uneasy, then somewhat drowsy, these symptoms being followed by pronounced twitching of the face muscles, particularly those near the lips. The eyelids tend to blink and the head rises and falls, and convulsions appear intermittently. A sudden noise or the touch of some object produces intense muscular rigidity. The rate of breathing is changeable throughout, the animal often appearing to be panting. As the animal collapses, severe convulsions follow which end in death.

Slightly less than 5 pounds of plant per hundredweight of animal is sufficient to kill a sheep, while 17 pounds has killed, in 3 hours and 40 minutes, a steer weighing 298 pounds. ${ }^{(41)}$

The habit of growth of the plant indicates that grubbing may be practicable where it occurs in dense patches. Herders should see to it that the animals are kept off areas heavily infested with fitweed, or that the areas are fenced off. As a temporary measure, cutting and burning each year's growth, before livestock are placed on the range, has proved effective under some conditions.

\section{WESTERN CHOKECHERRY}

Western chokecherry, Prunus demissa (Nutt.) Dietr., a member of the rose family (Rosaceae), is also called western wild cherry or merely chokecherry.

Description and Distribution.-This is a deciduous shrub or small tree, 2 to 30 feet high, with thick, acute-pointed, tooth-edged leaves. It has small white flowers growing thickly in terminal racemes, 2 to 4 inches long. The fruits are red or dark-purple berries which have a bitter and astringent taste. These hang on the trees until late autumn. The flowering period is from April to July (fig. 16 A).

The species is rather widely distributed in the state (fig. 17), occurring mostly in scattered patches between elevations of 500 and 7,500 feet, but it is not frequent in the Coast ranges. Although it usually inhabits moist places, such as those along creeks and rivers, it is somewhat common on semidry slopes in the southern California mountains.

Nature of Injury and Animals Affected.-The deadly prussic or hydrocyanic acid is found in the leaves, the bark, and the stones of the fruit. The pulp of the fruit is harmless.

Sheep and goats are often affected by western chokecherry on the range, and occasionally there are rather heavy losses of cattle. The leaves constitute the principal forage parts, the sheep nipping them off as they pass along. Leaves from young shoots are more poisonous than those from mature plants; thus danger of poisoning is less in late summer. ${ }^{(36)}$ 
Many sheep die each year from feeding upon western chokecherry. It is probable that in parts of California, as in Nevada, ${ }^{(39)}$ losses of cattle are occasionally serious. Horses probably seldom consume enough of the leafage to cause death. Whole bands are almost never affected; rather only individual sheep die. A short period elapses, sometimes only a few

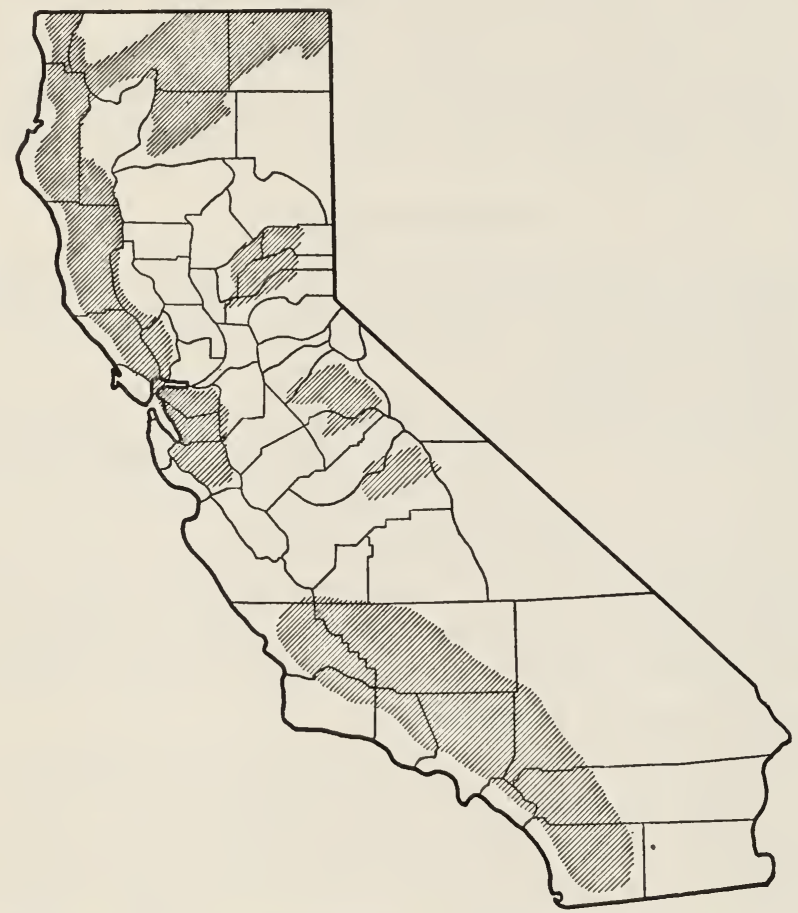

Fig. 17.-Distribution of western chokecherry (Prunus demissa), indicated by shaded areas.

minutes, after sheep have eaten toxic amounts before the symptoms appear, and death comes quickly. The poison exerts a depressive action over the whole nervous system, producing giddiness and difficult breathing, followed by vomiting. In severe cases the pupils are dilated, the animals have convulsions or spasms, and death results from general paralysis. ${ }^{(110)}$

The quantity of leaves required to poison a sheep varies with the season, the size of the animal, the amount of moisture contained in the leaves, the amount of forage in the stomach, and the rapidity with which the leaves are eaten. Feeding tests with sheep made between April and August showed that for each hundredweight of animal live weight, 3.23 ounces of leaves caused slight poisoning symptoms; 3.80 ounces caused severe illness followed by recovery; and 4.30 ounces, or a little 
more than 1/4 pound, caused death. After August when the leaves were dry, no symptoms appeared until nearly a pound per 100 pounds of live weight was eaten. ${ }^{(36)}$

Preventive Measures.-No treatment is likely to be of great aid, but the use of emetics, stimulants, and lard have been suggested.(110) As poisoning usually takes place when sheep are being driven over trails bordered with chokecherry, stockmen should take care that the drive is not started until the animals have been well fed. Where there are large amounts of the plant, the route should be changed to avoid risk of poisoning.

\section{THORN APPLES}

The thorn apples, of the nightshade or potato family (Solanaceae), are also known as Jimson weed, Jamestown weed, tolguacha, devil's apple, mad apple, and stinkweed.

Plants of the genus Datura are recognized by their coarse growth and by their rank smell. The leaves are large, oval in shape, and petioled. Large white, or white and purple, flowers occur singly on short stalks in the forks of the branching stems. The tubular calyx is 5-toothed, and the corolla is shaped like a funnel. The fruit is a prickly or spiny capsule.

The three poisonous California species are true Jimson weed or stramonium (Datura stramonium L.), tolguacha (D. meteloides DC.), and purple thorn apple (D. tatula L.).

True Jimson weed is the most troublesome of the genus. ${ }^{(52)}$ It is a coarse, very rank-smelling annual, with greenish stems 1 to 5 feet high, bearing large-toothed or lobed leaves 3 to 8 inches long. The flowers are funnel-shaped, 4 to 5 inches long, and white or light lavender in color. The fruits are round capsules, with stout prickles. May to October is the flowering period (fig. $16 \mathrm{~B}$ ).

Jimson weed is an introduction from the Old World. Although seldom growing densely it is widely distributed throughout California along roadsides, corrals, orchards, vacant lots, and waste places of low altitudes.

Tolguacha differs from Jimson weed in having much larger flowers, which are commonly 7 inches wide and 9 inches long.

This plant occurs in the San Joaquin and Sacramento valleys, on the coast of southern California, and from Inyo County south to the Colorado Desert. It grows along waysides in sandy places and canyon bottoms, mostly at elevations of 100 to 4,000 feet. The flowering period is from June to September.

Purple thorn apple closely resembles true Jimson weed, but is distinguished from it by its purple stems and flowers. This species, too, is a 
naturalized plant and has much the same distribution in California as Jimson weed, occurring along bars of rivers and banks of ditches and creeks.

These three poisonous species of Datura contain the same toxic principle. All parts of the plants are poisonous, the seeds being the most dangerous, ${ }^{(110)}$ and next the young leaves. Toxicity diminishes as the plant dries.

Typical symptoms are nausea, great thirst, and severe convulsions, especially before death. For cattle, 6 to 12 ounces of the tops are fatal. ${ }^{(18,16)}$ Horses are killed by 6 to 8 ounces of the tops, and sheep and goats by 3 to 8 ounces. They have also killed mules, ${ }^{(48)}$ and occasionally human beings have been poisoned. Under range conditions the plants cause little trouble, but when animals are confined to intensively used pastures, they cause heavy losses. Mowing the plants before seed maturity and burning them, followed by revegetation of the lands with wholesome forage, is the best known means of prevention. Care should be taken not to include these plants in hay.

\section{BLACK NIGHTSHADE}

Black nightshade, Solanum nigrum L., a member of the nightshade or potato family (Solanaceae), is also known as common nightshade, garden nightshade, deadly nightshade, and stubble-berry. It is the only species of the genus in California definitely known to be poisonous to all livestock. Human beings also have been poisoned by it. Animals poisoned lose their sense of coördination, have diarrhea, eat little, and become very weak. Solanum rostratum Dunal., popularly known as sandbur or buffalo-bur, has been suspected, but its poisonous properties have not been demonstrated nor have livestock been authentically reported to have been killed by this plant. The prickly burs, however, sometimes cause serious mechanical injuries. ${ }^{(110)}$

Black nightshade is a low, much-branched annual with a spread of 1 to 3 feet. The leaves are pointed-ovate. Some of them subtend groups of drooping whitish or purplish flowers. The distinctive round, smooth berries, at first green, turn dark blue or blue-black as they ripen. The flowering period is from June to November, the same plants often having both buds and mature fruits late in the summer.

Although introduced from Europe, black nightshade has become widely distributed throughout the state.

Black nightshade contains the narcotic poisonous principle solanin, which is found in small amounts in all its parts. The berries, which are somewhat edible, are not especially poisonous but should be avoided in all stages, especially when green. 
Symptoms are associated with a craving for water, diarrhea, loss of appetite, extreme weakness, and lack of coördination.

Grubbing or cutting before the fruit ripens is a means of eliminating this plant on areas where livestock are poisoned. It is held by some that black nightshade is an indicator of overgrazing. In any event, on wellvegetated areas the writers have never observed this plant to be abundant.

\section{COCKLEBUR}

The cockleburs, genus Xanthium, belong to the sunflower family (Compositae). Other popular names are sheep bur, burweed, hedgehog, sea burdock, clotbur, ditchweed, bottom bur, and Spanish thistle. They are poisonous to cattle, sheep, horses, hogs, and chickens.

Description and Distribution.-Cockleburs are coarse, branching annuals, 2 to 4 feet high, with roughened stems, more or less angled and tinged with red or brown, or irregularly spotted. The leaves are alternate, somewhat heart-shaped, lobed or toothed, and covered on both surfaces with minute hairs. Greenish-yellow disk-like flowers are borne in small unisexual heads, giving rise to a fruit bur covered with stout bristles, singly or doubly beaked. Each bur contains two seeds which may retain their germinating power several years. The flowering period is throughout the summer.

These plants are distributed throughout California on low alkaline grounds, in moist waste places around barnyards, in pastures, and along the shores of rivers, lakes, ditches, and ponds. They are exceedingly abundant in marshy lands, often covering hundreds of acres. Cockleburs are widely distributed in the United States. The four species in California, ${ }^{(69)}$ namely, Xanthium canadense Mill. (fig. $16 C$ ), X. calvum M. \& S., X. campestre Greene, and X. spinosum L., are so much alike and differ so little in their poisonous properties that no attempt is made to distinguish between them.

Nature of Injury and Animals Affected.-The toxic substance of cocklebur is a glucoside, known as xanthostrumarin. The stage when the cotyledons have just emerged from the ground, and before the first true leaves are formed, is the time when they are highly relished by foraging animals, and the time when most poisonous. After the leaves are fully formed, on the other hand, these plants are only midly toxic, and are seldom eaten, probably because of the bitter taste which is developed in the later stage. ${ }^{(103)}$ The seeds are even more poisonous than the young plants.

Although numerous cattle and sheep have been killed by eating cocklebur plants, the most severe losses have been among hogs, especially 
young pigs, probably because they appear to eat them more readily. Losses have also occurred among horses and colts. The entire young tender plants, and possibly some of the seeds, are pulled out and consumed, causing heavy losses annually.

The symptoms of poisoning are depression, nausea, accompanied by vomiting, rapid and weak pulse, and a low temperature. "Vomiting was not noticed in either cattle or sheep, but in cattle there was quivering or trembling of the muscles. Before death there are frequent spasmodic movements, but sometimes the animals die quietly. The symptoms ordinarily appear a few hours after the plant is eaten and commonly continue for only a few hours."(102)

Experimental feedings have shown that cocklebur herbage is about equally as toxic to sheep as to pigs. The lethal dose is $1 \frac{1}{2}$ per cent of the animal's weight and the toxic dose may be as little as half that amount. For cattle about 3 per cent of their weight is a lethal dose. ${ }^{(103)}$

Inasmuch as the seed may germinate continuously between April and September, young highly poisonous seedlings are a menace throughout that entire period.

The burs also cause rather serious mechanical injury to foraging animals. It has been claimed that hogs have been killed by eating them, either because of the mechanical irritation caused by the spines or by the poisoning effect of the burs themselves. The claim of the latter has not been disproved by recent studies. Burs in the wool of sheep seriously affect the value of the wool.

Preventive Measures.-The continued beneficial results from the use of fats and oils, like unskimmed milk, bacon grease, lard, and linseed oil, show that they are distinctly valuable remedies. ${ }^{(103)}$ Under range conditions, however, they are of little value because of the difficulty of administering them.

Since cockleburs are annual plants they can be destroyed by cutting or pulling before the burs mature. It must be remembered, however, that only one of the two seeds contained in the bur germinates the first year, resulting in another crop of seedlings the year after, or even several years after the plants are destroyed. Spraying the seedling plants with a solution of copper sulfate has been suggested as a means of cheaply ridding land of cockleburs. ${ }^{(113)}$

\section{WESTERN SNEEZEWEED}

Western sneezeweed, Helenium hoopesii Gray, a plant of the sunflower family, also called yellow weed and sunflower, is the only species of the genus Helenium in California which causes livestock poisoning. 
Description and Distribution.-Western sneezeweed is a stout perennial, 1 to 3 feet high, with one or more leafy stems, often forming dense clumps by spreading vegetatively from the crown. The plant is whitehairy when young, but becomes glabrous and smooth with age. The leaves are alternate, thick, entire, pale green, and sessile, or the lower ones have long tapering bases. There may be one or several terminal flower heads, resembling small sunflowers with brownish-orange disks, and outer strap-like yellow petals or ray flowers (fig. $16 \mathrm{D}$ ). The blossoming period is from June to August.

This plant is found in the Sierra Nevada from Tulare to Tuolumne County, and also in the Warner Mountains of Modoc County. It ascends to timber line, being found between elevations of 6,300 and 11,000 feet, where it grows in mountain valleys commonly along streams. It develops best on sunny hillsides in moist, well-drained soil.

Nature of Injury and Animals Affected.-An exceedingly toxic glucoside, called dugaldin, is reported to be the poisonous agent. It is found most abundantly in the leaves, occurring also in the stems, flowers, and seeds, and to a lesser extent in the roots. Nevertheless feeding tests show that different parts of the plant are about equally poisonous, and that there is little difference in toxicity between the green and the dried plants. There is an apparent tendency to slightly greater toxicity late in the growing season than at any other time. ${ }^{(91)}$

Sneezeweed is poisonous to sheep, cattle, and horses. Average feedings to sheep of the whole plant of 2.17 pounds daily for 21 days produced sickness or death, and average feedings to cattle of daily amounts of 1.68 pounds for 30 days produced symptoms of illness. Since the dugaldin present is a cumulative poison, most cases of range poisoning are the result of feeding on this plant extending over many days to several weeks, although the symptoms may not be noticed until an unusually large dosage is eaten in one day. Affected animals become very low in vigor and in flesh. Sheep, presumably because of their inherent fondness for broad-leaved herbs, are often affected. Horses and cattle are seldom poisoned.(75) This plant is the cause of what is called the "spewing sickness," from which there are rather numerous losses of sheep in California each year, and a few fairly well authenticated losses of cattle. ${ }^{(91)}$

In chronic cases of this illness the most prominent symptom is vomiting, which in range animals is practically the only symptom noticed by herders. It does not always appear, however, in chronic cases and it never appears in acute cases. Other characteristic symptoms are general depression and weakness, weak and irregular pulse, and bloating. Death, without convulsions, comes on quietly. 
Prevention.--Restoration of the range by revegetation with the better forage is especially important where this plant shows vigorous invasions or occurs in some abundance. Little can be accomplished by attempts at extermination because the plant is too widely distributed. Prevention lies chiefly in proper handling of livestock. Herders should recognize the plant and take care that the animals do not feed day after day on infested areas.

\section{SPRING RABBIT-BRUSH}

Spring rabbit-brush, Tetradymia glabrata Gray, the only species of the genus Tetradymia found in California that is known to possess poisonous qualities, is a member of the sunflower family.

Description and Distribution.- Spring rabbit-brush is a low, rounded bush, 1 to 3 feet high. The older branches are gray, but the new growth is greenish white. The small fleshy leaves are smooth, somewhat pointed, and borne in groups on the stem. The plant makes all of its growth in the spring, usually by the middle of June, and is dormant and leafless the remainder of the year. Dense clusters of small yellow flowers, the latter 0.38 to 1.40 inches in length, grow on the ends of the new twigs (fig. 18). The blossoming period is May and June. This species is found in low hills in desert-like situations from the Mojave Desert to Oregon and Utah.

Nature of Injury and Animals Affected.-Earlier investigators concluded that poisoning was due to the presence of an abundance of potash, but more recently the toxic properties are reported to be caused by some organic material, probably of a resinous nature. ${ }^{(37)}$ It is presumed that the buds and leaves, which are abundant in spring, are the most poisonous parts.

Because of its low palatability to livestock generally, cattle and horses are not known to be poisoned by spring rabbit-brush. Moreover, feeding trials in Nevada with cattle were negative. ${ }^{(37)}$ Sheep, however, graze the buds and leaves in places where the forage is limited and of poor quality, with serious results. The largest loss recorded was in a band of ewes and lambs of which approximately 1,000 ewes died. Other losses recorded have been as high as 500 animals. A series of feeding tests showed that the poison is eliminated from the body of sheep so slowly that the effects are the same when a certain amount of the plant is fed in small quantities during a period of 12 or more days as when the same amount is fed in larger quantities over a shorter period; the poison is cumulative. Two pounds fed each day for two days is fatal, and $31 / 2$ to 4 pounds fed at one time is fatal. Thus far, little progress has been made in the treatment of the sick animals. 
Clinical observations have failed to reveal sufficiently defined symptoms by which positive diagnosis of poisoning can be made, and specific medical treatment of sheep suspected of being poisoned has been unsuccessful.

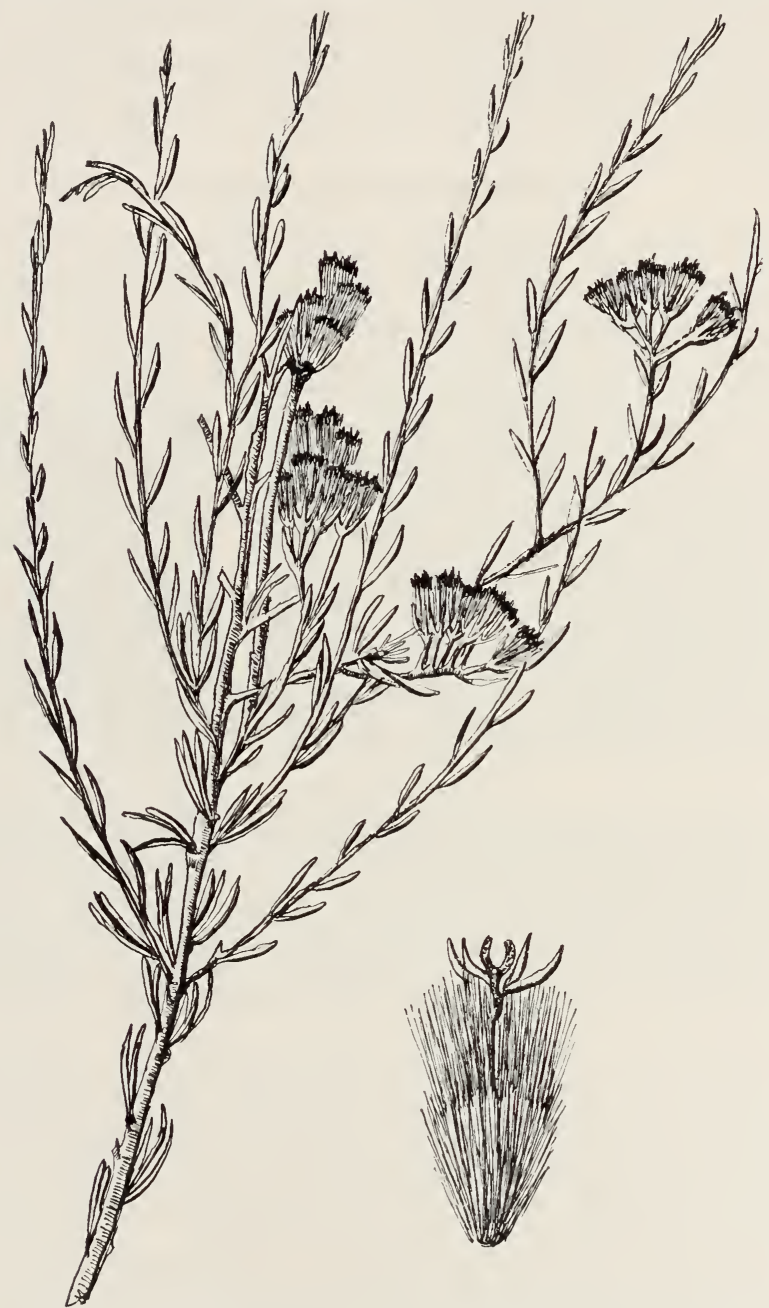

Fig. 18.-Spring rabbit-brush (Tetradymia glabrata).

Range losses may be largely prevented by refraining from turning hungry sheep on areas supporting spring rabbit-brush, especially early in the season, and by improving the forage conditions as soon as possible.

\section{HORSETAILS OR SCOURING RUSHES}

Horsetails or scouring rushes belong to the nonflowering horsetail plant family (Equisetaceae). They are also called bottle brush, snake's pipe, 
snake grass, pine top, pine grass, meadow pine, and jointed rush. Horses have suffered most from feeding upon these plants. The genus Equisetum consists of perennial plants with jointed, branched, extensively creeping rootstocks, and usually erect, hollow, jointed stems. The aerial stems may be simple or have whorled branches. They are regularly striated or ridged. The leaves are simple, much reduced, and united into a sheath at the nodes.

Although all six species found in California may be toxic, only four are known to have caused poisoning. These are: common horsetail (Equisetum arvense L.), smooth scouring rush (E. laevigatum A. Br.), common scouring rush (E. hyemale L.), and marsh horsetail (E. palustre L.). Common horsetail has caused the most trouble in California and elsewhere.

These four species represent two types of plants of the genus Equisetum. The first, common horsetail and marsh horsetail, have two kinds of shoots-an unbranched, fertile, or fruiting shoot, pale brown, bearing a cone at the summit containing the spores; and a vegetative nonfruiting, much-branched shoot resembling a horse's tail. The fruiting stem appears early in the spring and quickly dies down; then the nonfruiting stem develops and lasts throughout the summer and early fall.

The other two species, the smooth scouring rush and the common scouring rush, have but one kind of aerial stem-a stout branched or unbranched, evergreen shoot. The ridges of this stem are commonly smooth, and there usually is a narrow black-and-white girdle at the base of the sheath.

The horsetails and scouring rushes are found throughout California at altitudes ranging from sea level to 8,000 feet in elevation. They grow in wet places or in sandy soil, being most common along streams and marshes.

The toxic principle in horsetails and scouring rushes is not known but it is probably similar to that in bracken fern, for the effects on the animals are much the same. There is lack of muscular control and general weakness. Horses, particularly colts, are the animals most affected, although both sheep and cattle have been reported poisoned from eating these plants.

Preventive measures are the same as those given for bracken-fern poisoning.

\section{POISONOUS MUSHROOMS}

Livestock, as well as humans, are poisoned by certain mushrooms. Among the poisonous species, fly agaric, Amanita muscaria (L.) Fr., also called fly killer and deadly amanita, has been reported as causing livestock 
losses (fig. $19 A$ ). It is a small fungus characterized by a very brightyellow, orange, or scarlet cap, flecked with white. Another very poisonous species, known as death cup (A. phalloides L.), is large, being 3 to 6 inches high. It has a satiny cup, 3 to 5 inches broad, without worts, and varies in color from white to brown, the white or yellowish white being the most common (fig. $19 \mathrm{~B}$ ). A third highly poisonous species, known as

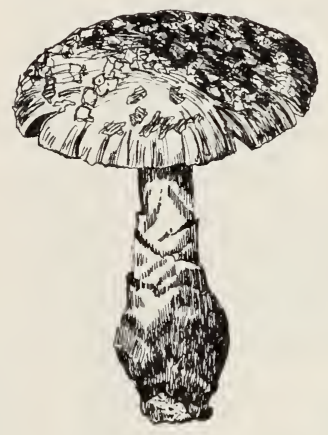

A

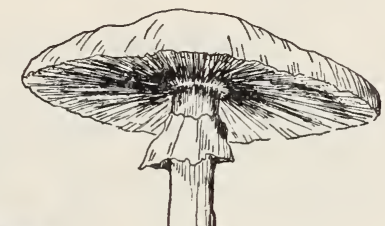

Fig. 19.-Fungi poisonous to livestock: $A$, fly agaric (Amanita nuscaria); and $B$, death cup (A. phalloides).

bull or vernal amanita (A. verna), differs little from death cup, and is white in color. These are the three most deadly mushrooms although various others have been reported to cause poisoning.

All three of these species occur in California, often in open pastures but more commonly in pine forests where they sometimes grow in great abundance.

Symptoms usually appear within a few hours after eating. First there is extreme difficulty in breathing, followed by profound stupor, often preceded or accompanied by cold sweats, giddiness, and lockjaw. Fly fungus usually does not cause abdominal pain but death cup poisoning is often accompanied by cramps and convulsions.

There is no known antidote for amanita poisoning but in all such cases a cathartic should be given as soon as possible. $A$ veterinarian should be called immediately.

Usually livestock will not eat mushrooms or toadstools, but if they are observed doing so and there are poisoned animals in the herd or band, they should be removed to another area, until these fungi have dis- 
appeared. Usually they last only a few days. It is not possible without special study to distinguish between a poisonous and a nonpoisonous toadstool, hence all had best be considered dangerous.

\section{ERGOT}

Ergot, genus Claviceps, also known as spur kernels, bright kernels, and spurred rye, is a fungus which is parasitic on flowers. It is often seen on the flowers or fruits of various grasses and cereal crops.

The fungus is most readily recognized in its fall and winter stage, by a characteristic fruiting body. This is a purplish-black, hard, straight, horn-like structure about $1 / 4$ to $1 / 2$ inch long, which may be observed on the flowers of the host plants in late summer and autumn. Later it drops to the ground where it lies through the winter. With the advent of warm weather the following year the fruiting part produces spores. These spores are borne to plants by insects, flies, wind, and other agencies and new plants are then infected.

Ergot is widely distributed in California and throughout the world. Although it occurs rather commonly on small grains, flowers of various native grasses-notably brome grasses and barley grasses-are often infested.

While cattle have suffered most from ergot poisoning, mules, horses, sheep, hogs, dogs, cats, fowl, and even man have been affected. ${ }^{\left({ }^{53}\right)}$ Ergot poisoning is a well-known cause of abortion.

Two rather distinct types of symptoms are manifested in animals, namely, a nervous form, and a gangrenous or general form.

Various medicinal treatments have been proposed for ergot-poisoned animals, but none is applicable to range conditions. Since some forms of ergot cause animals to acquire a taste for ergot-infested plants, so that they much prefer them to healthy ones, it is best to remove the animals from infested fields if symptoms appear. Care also should be taken that no grain be sown which has ergot in it.

\section{POISONOUS PLANTS OF MINOR OR LOCAL IMPORTANCE}

Many of the species embraced in the following discussion are of limited abundance and distribution, and generally of very low palatability. Some contain dangerously large amounts of toxic substances only for a short part of the grazing season, whereas others may cause poisoning throughout the usual foraging period. Although generally less troublesome on the range than those already discussed, the species here listed should not be overlooked when confusing cases of poisoning are encountered. 
Of the species here concerned, a few are cultivated but mostly they are native range plants. Because of the rather distinct poisonous properties and reactions on the animals, the grasses are discussed as one group. The broad-leaved herbs, trees, and shrubs are treated in a second division.

\section{POISONOUS GRASSES}

Aside from the better-known grasses which under some conditions form prussic acid, a few other grass species occasionally cause poisoning. Of these, link grass, poison darnel, and sleepy grass are best known.
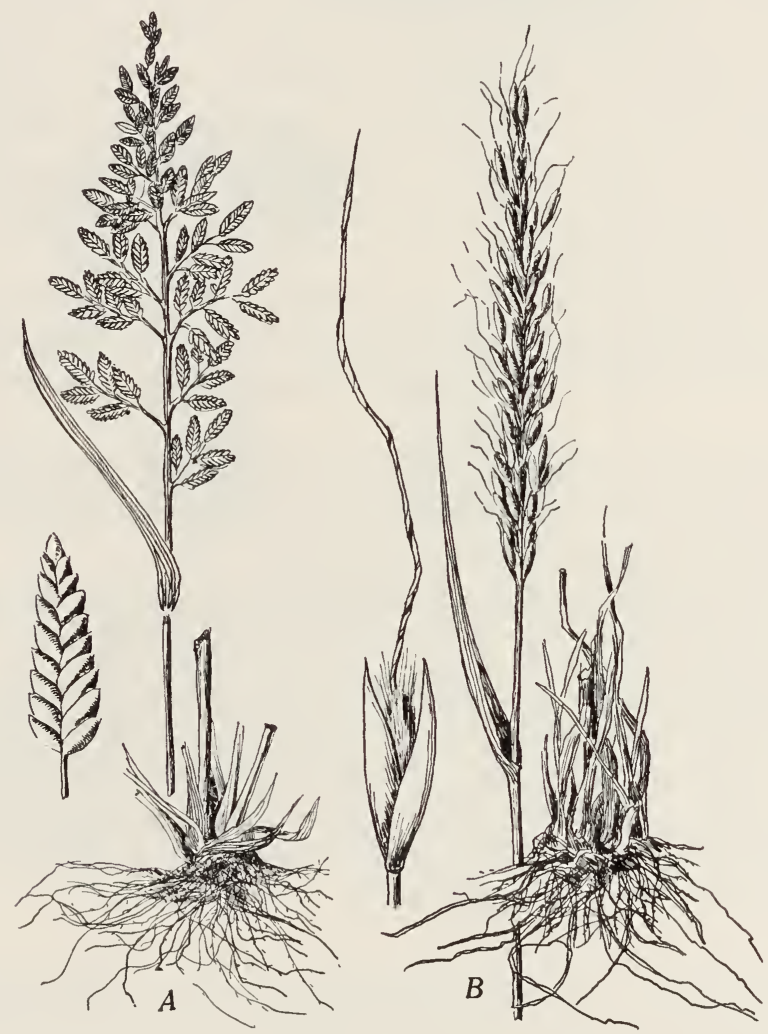

Fig. 20.-Grasses which sometimes poison livestock: $A$, link grass (Eragrostis cilianensis); and $B$, sleepy grass (Stipa robusta).

Link grass, Eragrostis cilianensis (All.) Link., also called stink grass, is a weed introduced from Europe.

It is a rather common autumn weed, recognized by the facts that the keel of the flower scale contains some rather conspicuous glands, and that the spikelets have many flowers (fig. $20 \mathrm{~A}$ ). It is found from Tehama 
and Butte counties southward and grows along roadsides, in fields, and waste places. When fresh it is strongly scented.

Horses may be made sick by eating large quantities of the fresh plant, or by consuming large amounts of it over a long period of time. ${ }^{(51)}$

Poison darnel (Lolium temulentum L.), also known merely as darnel, and sometimes as cheat, is similar in appearance to rye grass. It grows through the state in cultivated fields and waste places around habitations.

Since the toxic principle of this plant seems to be localized in the seed or grain, some investigators ${ }^{(48)}$ believe that a fungus containing the poisonous substances infests the seeds.

Horses, cattle, sheep, and man are poisoned. ${ }^{(16)}$ No outstanding cases have been reported in California.

Darnel poisoning produces giddiness, drowsiness, uncertain gait, stupefaction (in older animals), vomiting, convulsions, loss of sensation, and sometimes death. The amounts of darnel necessary to kill animals have been stated to be as follows : Horses, 0.7 pound per 100 pounds live weight; ruminants, 1.5 to 1.8 pounds; poultry, 1.5 to 1.8 pounds; hogs, 1.8 pounds.

Since darnel is an annual grass it should be prevented from going to seed by mowing or cutting, where practicable. By obtaining pure grain and grass seed for sowing, it can be checked in its spread.

Sleepy grass (Stipa robusta Scribn.), ${ }^{(64)}$ illustrated in figure $20 \mathrm{~B}$, is similar in appearance to our common and highly valuable needle grass and has the reputation of containing a narcotic which causes drowsiness and sleepiness in loorses and sheep that have fed heavily upon it. It is said to affect horses particularly. They appear to go into a profound slumber, from which they always recover. Cattle appear not to be affected. Both green and dry or mature plants have been reported to be equally poisonous, although for this there is no proof since the toxic principle has not been found in spite of several attempts to isolate it. No authenticated cases of poisoning have been reported in California, possibly because the species does not occur abundantly in the state. Sleepy grass occurs from Tulare and Santa Barbara counties southward.

Western yew (Taxus brevifolia Nutt.), a small tree, has caused illness and death among cattle when they have browsed on the leaves, twigs, and fruits. If enough of the plant is eaten, poisoning takes place quickly. ${ }^{(59)}$ Western yew is found in deep, shady canyons along the coast, from the Santa Cruz Mountains to Mendocino County, and in the interior throughout the Sierra Nevada.

Cat-tail (Typha latifolia L.) is common in marshy places throughout California. It is suspected of being poisonous to livestock, ${ }^{(53)}$ although it is not known to have caused serious trouble. 
Sand lily (Leucocrinum montanum Nutt.) has been reported to be very fatal to sheep, especially after the fruit is developed. ${ }^{(18)}$ It is plentiful in restricted areas in mountain valleys of the northern Sierra Nevada.

Sheep sorrel (Rumex acetosella L.), curled dock (Rumex crispus L.), knotweed (Polygonum aviculare L.), lady's thumb (P. persicaria L.), water pepper (P.hydropiperoides Michx.) -in fact, many species of the buckwheat family-contain acid or smarting substances which may cause dermatitis; or if eaten in large quantities, gastric disturbances. Horses and sheep are the most frequently poisoned by them. ${ }^{(51)}$

The oaks (Quercus) furnish important forage for cattle, sheep, and goats, on many ranges. Cattle especially partake heavily of the young tender foliage in the spring, the time when poisoning is most likely to occur. ${ }^{(78)}$ An exclusive diet of oak, however, may result in heavy animal losses. If other food is present with the oak there are usually no bad results.

Corn cockle (Agrostemma githago L.) contains, in its seeds particularly, a poisonous saponin. ${ }^{(19)}$ Corn cockle is found in grain fields and is, therefore, harvested with the cereal crops. Poisoning occurs in horses, sheep, cattle, goats, and poultry. ${ }^{(16)}$

Cow-herb, or cow cockle (Vaccaria vulgaris Host.) contains the same injurious properties as corn cockle. The poison produces a burning sensation in mucous membranes of the digestive tract. ${ }^{(16)}$ It is a grain-field weed of wide distribution in the state.

Marsh marigold (Caltha biflora DC.), since it contains poisonous substances, should be suspected even though no cases of poisoning have been reported in California. ${ }^{(48)}$ Generally it is unpalatable. Marsh marigold is a high-mountain species of the northern part of the state.

Baneberry (Actaea spicata L. var. arguta Torr.), a poisonous, perennial herb, found on wooded and brushy hills, is common in California, occurring most abundantly on north slopes. Since animals rarely feed upon it, they are seldom affected.

Soapwort or bouncing bet (Saponaria officinalis L.), an escaped garden species, also contains a poisonous saponin in all parts of the plant, but particularly in the root. No cases of poisoning, probably because of its low palatability, have been recorded in California. It is common in the Sacramento Valley.

Cursed crowfoot or celery-leaved crowfoot (Ranunculus sceleratus L.) contains in the aerial parts when green the poison anemonol. ${ }^{(13)}$ When dried the plant may be eaten with impunity. ${ }^{(48)}$ Anemonol, an acrid and very toxic principle, raises blisters and ugly sores on the skin, 
besides causing characteristic convulsions. The milk from such poisoned cows becomes reddish and has a bitter flavor. While all animals may be affected by this plant, it is especially dangerous to cattle. It is found in shallow pools or muddy margins of lakes in Modoc County.

The leaves and fruits of California buckeye or horse chestnut, Aesculus californica (Spach) Nutt., which is very common on dry hills or canyon sides throughout the Coast ranges and Sierra Nevada, are reputed to be poisonous to cattle during certain seasons of the year. ${ }^{(60)}$ It is believed that a small quantity of the unhulled fruit will cause cows to abort. ${ }^{(18)}$ Bees also are poisoned from the nectar in the flowers. The Indians, however, made the fruits into bread, evidently after removing the poison by roasting, ${ }^{(20)}$ and used both the roots and the fruits for soup.

Buckthorns (Rhamnus sp.) contain a bitter and poisonous principle, but because of their low palatability they are seldom eaten in sufficient quantities to be serious. ${ }^{(51)}$

Turkey mullein (Eremocarpus setigerus Benth.) is a low, grayish annual covered densely with stiff hairs. It is common throughout California, on dry open areas, low hills, and valley plains from sea level to 4,500 feet in elevation. Sheep and hogs, which occasionally eat the plant, sometimes die from feeding upon it, presumably because of the solid indigestible balls which form in the digestive tract from the branched hairs of the stems and leaves. More than 20 of these balls, each the size of a hickory nut, have been taken from the stomach of a single sheep. "The California Indians used the heavy-scented herbage to stupefy fish in small streams in order that they might be caught by hand."(69)

Castor bean (Ricinus communis L.), a cultivated tropical plant naturalized in coastal southern California, has caused poisoning in horses, mules, cattle, sheep, hogs, and poultry. ${ }^{(18)}$ The poison is one of a class known as toxalbumins, specifically called ricinolein. This poison, even more deadly than strychnine and prussic acid, causes coagulation of blood in the vessels. Ulcers later appear owing to absence of an ample blood supply. Castor bean is sometimes planted in California as a catchcrop to check erosion on steep slopes. Such plantings should be avoided where livestock are likely to graze.

Garden spurge (Euphorbia lathyris L.), also called mole plant, mole weed, mole tree, gopher plant, wild caper, caper bush, and springwort, is found throughout coastal California in wet places. The fresh milky juice is exceedingly acrid and the fruit highly poisonous. Although cattle are rather resistant to this poison they are sometimes overcome by it. Goats will eat the plant extensively, with the result, it is said, that their milk possesses the toxic properties of the plant. ${ }^{(19)}$ 
Poison sanicle (Sanicula bipinnata H. \& A.), a perennial herb with a tuberous root, is known to be poisonous. Animals evidently avoid it, or do not eat it in quantity since livestock poisoning has not been reported in California. It occurs in the Coast ranges and Sierra Nevada.

Water parsnip (Sium cicutaefolium Gmel.), a plant found in deep marshes and ponds of northern California, is reported to be poisonous. This plant should not be confused with the extremely dangerous water hemlock (Cicuta sp.).

Cut-leaved water parsnip, Berula erecta (Huds.) Cov., is known to be poisonous, ${ }^{(13,110)}$ but has caused little trouble. It is a glabrous aquatic or marsh perennial 1.2 to 2 feet high, with simple pinnate leaves and sharply serrated leaflets. The stems are weak in comparison to water hemlock or poison hemlock. It is found in swamps and streams tliroughout coastal southern California, north through the deserts to Inyo County, and on into Siskiyou County. ${ }^{(69)}$

Two species of the dogbane family (Apocynaceae), Indian hemp (Apocynum cannabinum L.), and mountain hemp (A. androsaemifolium L. var. pumilum Gray), contain an acrid milky juice which is poisonous to livestock, especially cattle. When dry, they are not as poisonous as when fresh. Moreover, stock generally avoid these plants in pastures. ${ }^{(18)}$ Indian hemp is an erect lierb, 2 to 4 feet high with opposite, ovate, glabrous leaves, and greenish flowers. It is widely distributed in California along streams and river banks. Mountain hemp is a thickly branched plant, 5 to 8 inches high. The flowers are red-purple or pink to nearly white. It is found in loamy soils in the mountains from 4,000 to 9,000 feet in elevation, descending toward the coast to 300 feet. ${ }^{(69)}$

The oleander (Nerium oleander L.) is a common ornamental plant, whose leaves are well known to be powerfully poisonous. Stock are occasionally killed by eating them. ${ }^{(18)}$

Bindweeds or morning-glories (Convolvulus spp.) contain a poisonous milky juice, particularly in the roots, but seldom does the poison cause serious trouble. Hogs are affected more than other animals, although seldom seriously. ${ }^{(51)}$

Ground ivy, Nepeta hederacea (L.) Trev., is an introduction from Europe which has gained a foothold in the lower San Joaquin Valley. It is credited with having killed horses, but it is not reported to have affected cattle or sheep.

Purple foxglove (Digitalis purpurea L.) is a European garden plant, naturalized on the Humboldt and Mendocino coasts. When in the green state or in hay it oceasionally poisons horses. ${ }^{(18)}$

All species of lousewort (Pedicularis spp.) are suspected of being slightly poisonous to stock. ${ }^{(18)}$ 
Button-bush (Cephalanthus occidentalis L.) is found along streams in the Great Valley and in the Sierra Nevada foothills, from sea level to 1,000 feet in elevation. The leaves are whorled or opposite, have a bitter taste, and are probably poisonous to all animals that eat it. It produces spasms and paralysis if eaten in quantity.

Pimpernel, or poor man's weather-glass (Anagallis arvensis L.), a naturalized weed, has obtained a strong foothold in this state, mostly near the coast. Chemists have isolated a powerfully poisonous oil and a strongly active ferment from this plant. It is suspected of having caused death among horses in Orange County. ${ }^{(18)}$

Goldenrods (Solidago spp.) have been suspected of being poisonous to horses in Wisconsin. ${ }^{(18)}$ Studies in Nevada, where there have been several disastrous cases ${ }^{(46)}$ of sheep poisoning from grazing on the green plants, and also by eating it in hay, indicated that sheep were the only animals poisoned. Although no cases have been reported of livestock poisoning in California, such cases may have occurred. It is thought that the injury may be due to a fungus parasitic on the plant. ${ }^{18)}$

Yellowbrush, Chrysothamnus nauseosus (Pall.) Britt. var. speciosus Hall, is eaten to a considerable extent by livestock. Reliable reports indicate that it is poisonous under certain conditions. It is probable that serious results follow only when it is eaten in exclusion of other foods, or when the animals are underfed, or are in a weakened condition. It is widely distributed in the state, where it occupies the lower elevations.

Yarrow (Achillea spp.), common throughout pasture lands of California, contains glucosides and bitter alkaloids. If consumed in quantity by sheep, yarrow occasionally produces gastric and abdominal pains, with diarrhea and enuresis. ${ }^{(110)}$

Common burdock (Arctium minus Benth.), a naturalized weed found in cultivated fields, is probably poisonous. It is rarely eaten. ${ }^{(51)}$

Horseweed, or mare's tail (Erigeron canadensis L.) is irritating to the nostrils of grazing animals. Large quantities would have to be consumed before the terpene, which it contains, would produce serious effect. ${ }^{(51)}$ The weed is an introduction, common in waste places and half-cultivated fields.

Black or common sagebrush (Artemisia tridentata Nutt.) is eaten extensively by sheep, especially in fall and winter. Western stockmen have reported that black sagebrush is sometimes mildly poisonous to sheep. Horses that have fed extensively upon this sagebrush have also been reported to have become sick, but in neither case is there authoritative evidence of toxicity. ${ }^{(28)}$ The species is widely distributed in the state, oceupying high plains and mountains up to 6,000 feet. 
Mayweed or dog fennel (Anthemis cotula L.), common in yards and along roadsides, has a strong odor and acrid taste which make it unpalatable for stock. When eaten somewhat extensively it blisters the skin of the animals. ${ }^{(110)}$

Coneflower or niggerhead (Rudbeckia spp.) is considered poisonous to stock, ${ }^{(110)}$ in Iowa. Sheep will at times feed upon it but do not relish the plant highly.

Balsam root (Balsamorrhiza sagittata Nutt.) has been suspected of being poisonous to livestock, but probably is harmless unless eaten in large quantities. ${ }^{(21)}$ It occurs throughout the state between elevations of 5,000 and 8,000 feet.

\section{SUMMARY OF FACTS REGARDING THE MORE COMMON POISONOUS SPECIES}

For purposes of ready reference, some of the more essential facts pertaining to the poisonous species discussed in the preceding pages are brought together in table 2. This table shows where each important species, or plant genus, occurs most commonly in the state, and the habitat where it is most likely to grow abundantly. It lists the kinds of livestock which are most susceptible to poisoning by the different plants, and the parts of the plants which contain the toxic substances. It also points out the characteristic symptoms of the different animals which have fed on the poisonous species, which furnishes a clue to the particular plant which is causing the trouble. 


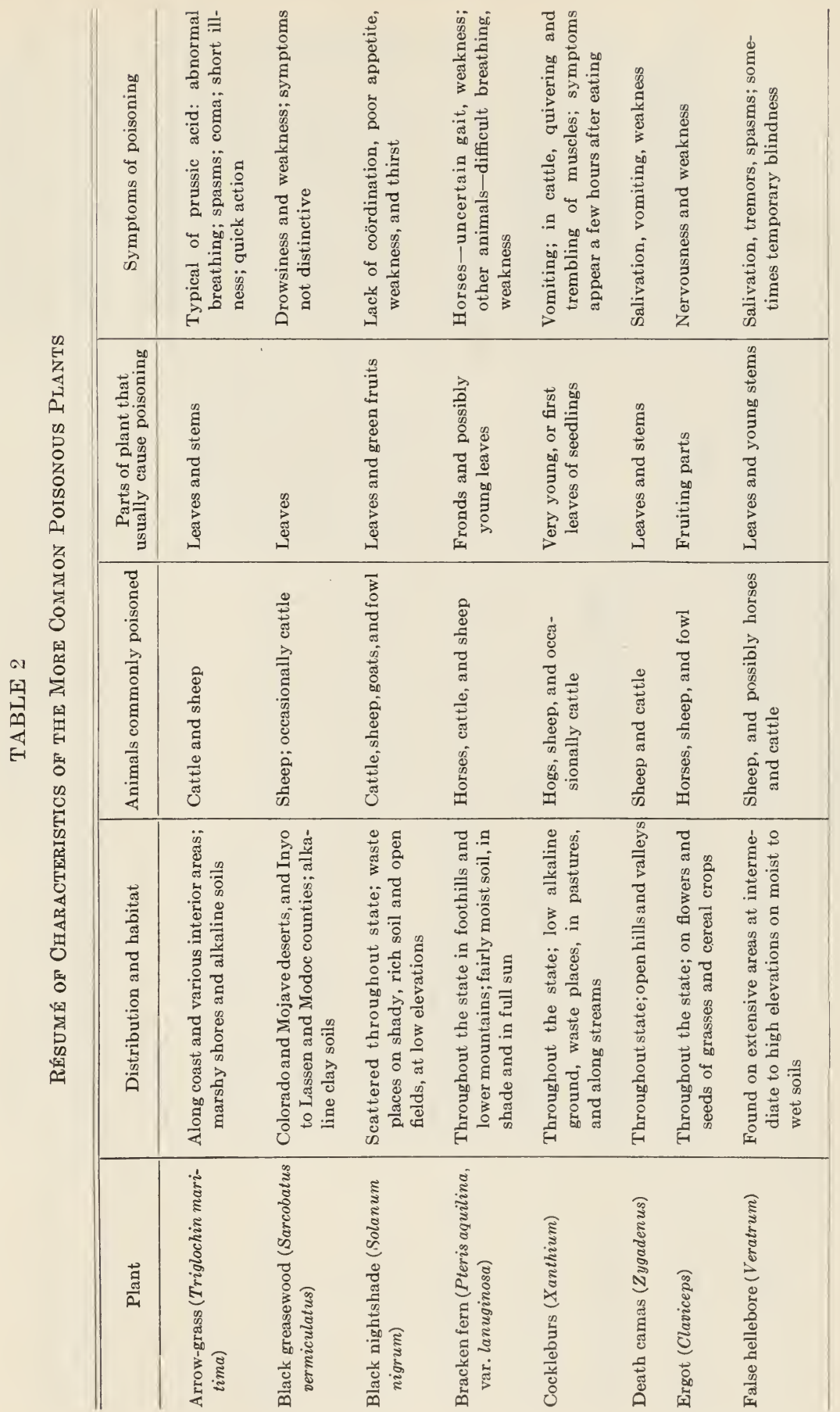




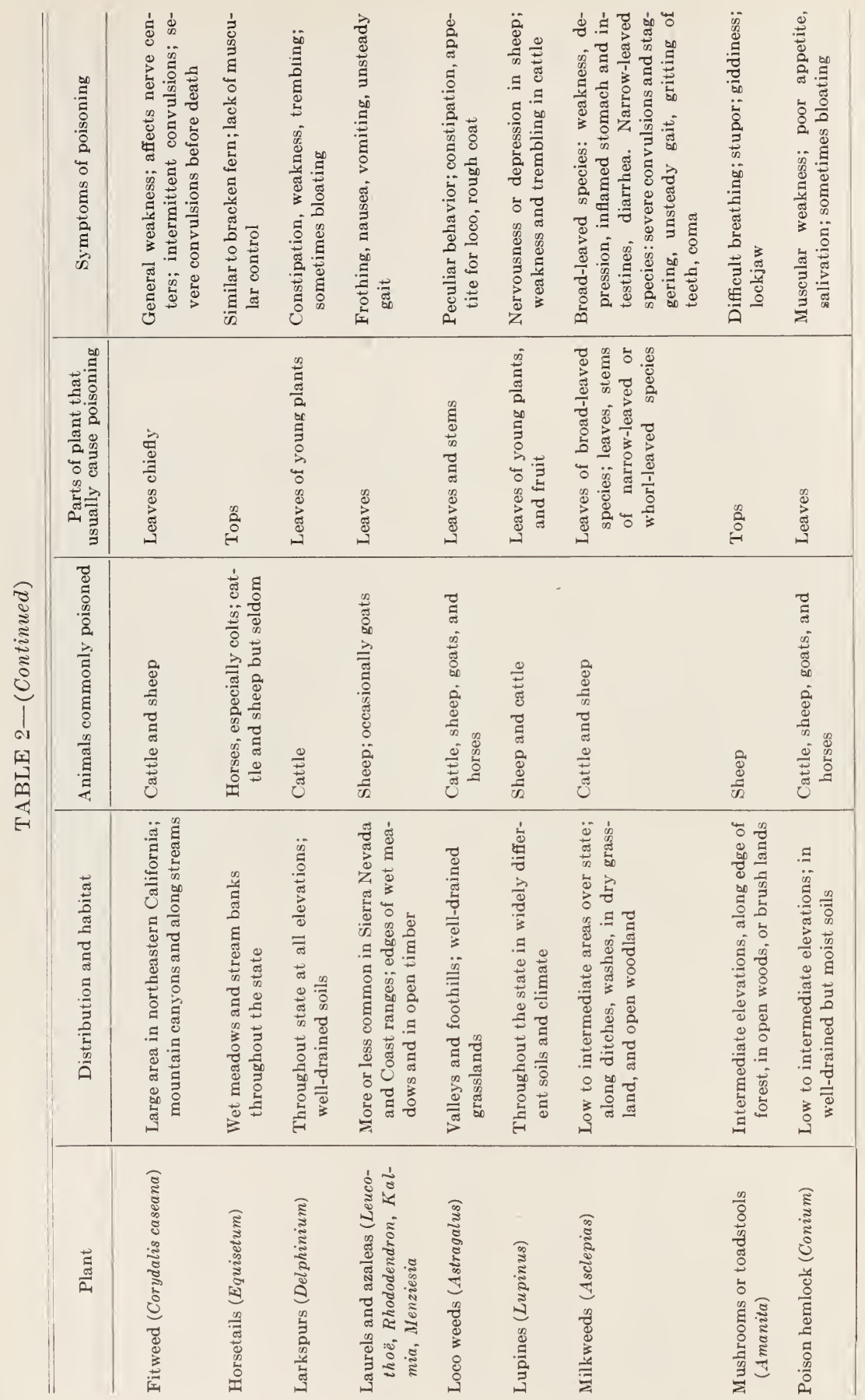




\begin{tabular}{|c|c|c|c|c|c|c|c|}
\hline 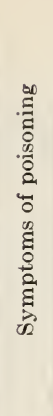 & 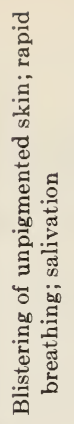 & 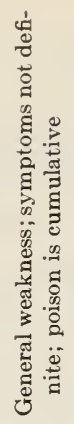 & 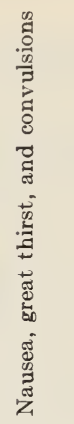 & 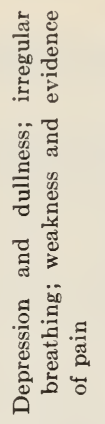 & 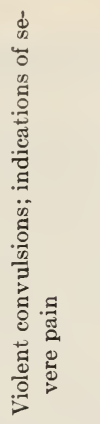 & 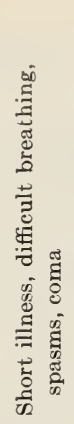 & 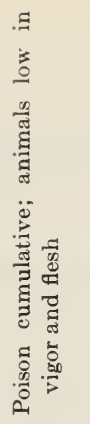 \\
\hline 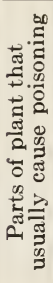 & 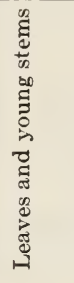 & 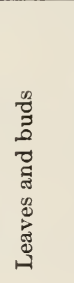 & 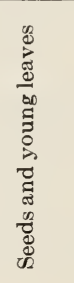 & 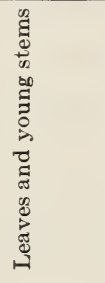 & 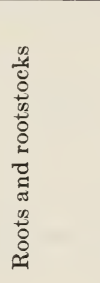 & 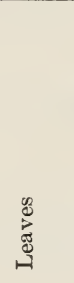 & 疍 \\
\hline 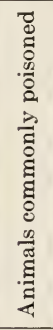 & 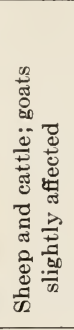 & $\begin{array}{l}\text { बेँ } \\
\text { ॠू }\end{array}$ & 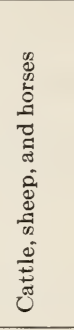 & 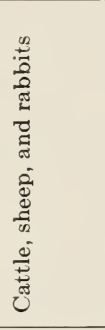 & 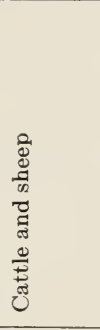 & 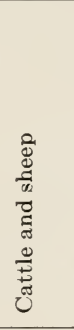 & 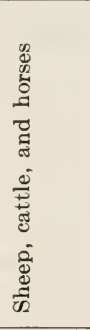 \\
\hline 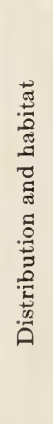 & 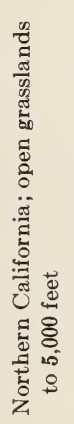 & 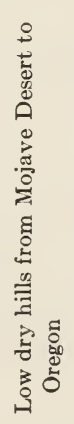 & 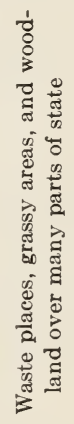 & 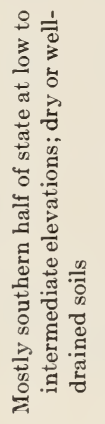 & 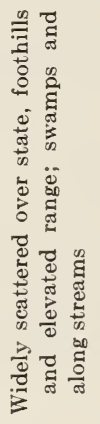 & 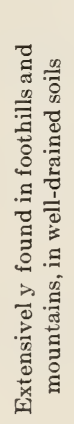 & 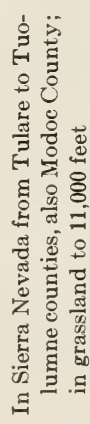 \\
\hline 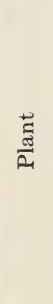 & 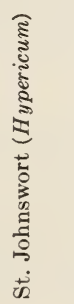 & 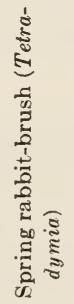 & 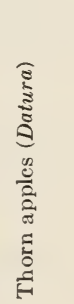 & 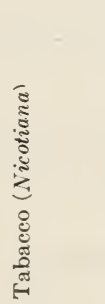 & 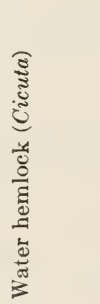 & 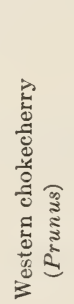 & 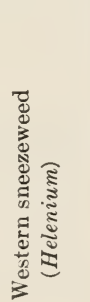 \\
\hline
\end{tabular}




\section{ACKNOWLEDGMENTS}

The authors take pleasure in acknowledging the assistance of those who have contributed to the prosecution of this work. To the late Miss Laura E. Marshall and to Mrs. Rosalind Johnson go the credit for the many illuminating plant drawings. To Mrs. K. W. Parker, who assisted in the compiling of plant distributions and in other ways, thanks are expressed. Dr. W. L. Jepson, Professor of Botany, offered the fullest possible coöperation both in making herbarium specimens available and in the use of the library facilities of the Department of Botany. Dr. H. L. Mason, Associate Curator of the Herbarium, was helpful in reading critical plant descriptions and in many other ways. To Mr. M. W. Talbot thanks are expressed for verifying and amplifying the data on the distribution of several of the more important species. Special acknowledgment is due Dr. A. B. Clawson, Physiologist, United States Department of Agriculture, for critically reading the manuscript and offering many valuable suggestions. 


\section{BIBLIOGRAPHY}

1 Abrams, LeRoy.

1917. Flora of Los Angeles and vicinity. 432 p. (See specifically p. 381.) Stanford Univ. Press, Stanford, California.

2 Aldous, A. E.

1917. Eradicating tall larkspurs on cattle ranges in the national forests. U. S. Dept. Agr. Farmers' Bul. 826:1-24.

3 Alsberg, C. L., and O. F. Black.

1912. Laboratory studies on the relation of barium to the loco-weed disease. U. S. Bur. Plant Indus. Bul. 246(Pt. II):39-61.

4 Beath, O. A.

1919. The chemical examination of three species of larkspurs. Wyoming Agr. Exp. Sta. Bul. 120:53-8.

5 BEATH, O. A.

1925. Lupine studies II. The silvery lupine. Wyoming Agr. Exp. Sta. Bul. 144:1-16.

6 BEATH, O. A.

1931. Poisonous plants of Wyoming. Wyoming Agr. Ext. Cir. 37:1-35.

7 Beath, O. A., J. H. Draize, and C. S. Gilbert.

1934. Plants poisonous to livestock. Wyoming Agr. Exp. Sta. Bul. 200:1-84.

$8 \mathrm{BEHR}, \mathrm{H} . \mathrm{H}$.

1888. Flora of the vicinity of San Francisco. 364 p. (See specifically p. 129.) Published by author, San Francisco.

9 Benthem, G.

1857. Plantae Hortwegianae. 393 p. (See specifically p. 323.) G. Pamplin Co., London.

10 Blankinship, J. W.

1903. The loco and some other poisonous plants in Montana. Montana Agr. Exp. Sta. Bul. 45:73-104.

11 Brewer, W. H., Sereno Watson, and Asa Gray.

1876. California Geological Survey (botany of California) 1:1-628. (See specifically p. 260 and 475.) Welch, Bigelow \& Co., Univ. Press, Cambridge, Mass.

12 Britton, N. L., and A. Brown.

1913. Illustrated flora of the northern United States. Vol. 3.637 p. (See specifically p. 30.) C. Scribners Sons, New York.

13 BRUCE, E. A.

1927. Astragalus campestris and other stock-poisoning plants of British Columbia. Canada Dept. Agr. Bul. 88:1-44. (See specifically p. 39-44.)

14 Candolle, A. P. DE

1828. Prodromus systematis naturalis regni vegetabilis. Vol. 3:1-494. Treuttel \& Wurtz, Paris. 
15 Candolle, A. P. DE

1830. Prodromus systematis naturalis regni vegetabilis. Vol. 4:1-683. (See spefically p. 4, 106-125.) Treuttel \& Wurtz, Paris.

16 Cary, C. A., E. R. Miller, and G. R. Johnstone.

1924. Poisonous plants of Alabama. Alabama Polytechnic Inst. Ext. Cir. 71:1-42.

17 Cavanilles, A. J.

1791. Icones et descriptiones plantarum 1:1-42. L. Gaygeur, Matriti (Madrid). 18 Chestnut, V. K.

1898. Preliminary eatalogue of plants poisonous to stock. In: U. S. Dept. Agr. Bur. Anim. Indus. 15th Ann. Rept.p. 387-420.

19 Chestenut, V. K.

1898. Principal poisonous plants of the United States. U. S. Dept. Agr. Div. Bot. Bul. 20:1-60.

20 Chestnut, V. K.

1902. Plants used by the Indians in Mendocino County, California. Contrib. U. S. Natl. Herbarium 7:294-422.

21 Chestnut, V. K., and E. V. Wilcox.

1901. The stock-poisoning plants of Montana. U. S. Dept. Agr. Div. Bot. Bul. $26: 1-150$.

22 Clawson, A. B.

1931. Two lupines shown to be poisonous to livestock. U. S. Dept. Agr. Off. Rec. 10(9):69-76. (See specifically p. 71.)

23 Clawson, A. B.

1933. Additional information eoncerning larkspur poisoning. Supplement to U. S. Dept. Agr. Farmers' Bul. 988. 2 p.

24 Clawson, A. B.

1933. Alpine kalmia (Kalmia microphylla) as a stock-poisoning plant. U. S. Dept. Agr. Tech. Bul. 391:1-10.

25 Coucir, J. F.

1922. The toxic constituents of greasewood. Amer. Jour. Pharm. 94:631-41.

26 ('ouch, J. F.

1932. Poisoning of livestock by plants that produce hydrocyanic acid. U. S. Dept. Agr. Leaflet 88:1-4.

27 Coulter, J. M., and J. M. Rose.

1900. Monograph of the North American Umbelliferae. Contrib. U. S. Natl. Herbarium 7:1-256. (See specifically p. 7-25.)

28 Coville, F. V.

1893. Botany of the Death Valley expedition. Contrib. U. S. Natl. Herbarium 4:1-363. (See specifically p. 149.)

29 Crawford, A. C.

1907. The larkspurs as poisonous plants. U. S. Dept. Agr. Bur. Plant Indus. Bul. 111(Pt. I):1-12. 
30 Crawford, A. C.

1908. Barium, a cause of the loco-weed disease. U. S. Dept. Agr. Bur. Plant Indus. Bul. 129:1-87.

31 CrawFord, A. C.

1908. Mountain laurel, a poisonous plant. U. S. Dept. Agr. Bur. Plant. Indus. Bul. 121(Pt. II):21-35.

32 Dayton, WM. A.

1931. Important western browse plants. U. S. Dept. Agr. Misc. Pub. 101:1-214.

33 DoDd, S.

1920. St. John's wort and its effects on livestock. Agr. Gaz. N. S. Wales, $31: 265-72$.

34 Durrell, L. W., and G. H. Clover.

1927. Poisonous plants of Colorado. Colorado Agr. Exp. Sta. Bul. 316:1-28.

35 Ewart, A. J., and J. R. Tover.

1909. The weeds, poison plants and naturalized aliens of Victoria. $110 \mathrm{p}$. Illus. Govt. Print., Melbourne.

36 Fleming, C. E., and R. Dill.

1928. The poisoning of sheep on mountain grazing ranges in Nevada by the western chokecherry (Prunus demissa). Nevada Agr. Exp. Sta. Bul. $110: 1-14$.

37 Fleming, C. E., M. R. MilleR, and L. R. VAWTER.

1922. The spring rabbit-brush (Tetradymia glabrata), a range plant poisonous to sheep. Nevada Agr. Exp. Sta. Bul. 104:1-29.

38 Fleming, C. E., M. R. Miller, and L. R. VAwter.

1923. The low larkspur (Delphinium andersoni), a plant of the spring range, poisonous to cattle. Nevada Agr. Exp. Sta. Bul. 105:1-22.

39 Fleming, C. E., M. R. Miller, and L. R. VAwter.

1926. The common chokecherry (Prunus demissa) as a plant poisonous to sheep and cattle. Nevada Agr. Exp. Sta. Bul. 109:1-30.

40 Fleming, C. E., M. R. Miller, and L. R. Vawter.

1928. The greasewood (Sarcobatus vermiculatus), a range plant poisonous to sheep. Nevada Agr. Exp. Sta. Bul. 115:1-23.

41 Fleming, C. E., M. R. Miller, and L. R. VAwter.

1931. The fitweed (Capnoides caseana), a poisonous range plant of the northern Sierra Nevada Mountains. Nevada Agr. Exp. Sta. Bul. 121:1-28.

42 Fleming, C. E., N. F. Peterson, M. R. Miller, L. R. Vawter, and L. H. Wright. 1920. The narrow-leafed milkweed (Asclepias mexicana) and the broad-leafed milkweed, or showy milkweed (Asclepias speciosa), plants poisonous to livestock in Nevada. Nevada Agr. Exp. Sta. Bul. 99:1-32.

43 Fleming, C. E., N. F. Peterson, M. R. Mil.ler, and L. R. Wright.

1921. Death camas (Zygadenus paniculatus and Zygadenus venenosus) plants poisonous to sheep and cattle. Nevada Agr. Exp. Sta. Bul. 101:1-31. 
44 Fleming, C. E., N. F. Peterson, W. R. Wright, and R. C. Louck.

1920. Arrow-grass, a new stock-poisoning plant (Triglochin maritima L.). Nevada Agr. Exp. Sta. Bul. 98:1-21.

45 Fleming, C. E., N. F. Peterson, W. R. Wright, and R. C. Louck.

1920. The poison parsnip or water hemlock (Cicuta occidentalis), a plant deadly to livestock in Nevada. Nevada Agr. Exp. Sta. Bul. 100:1-23.

46 Fleming, C. E., and B. F. Schapelle.

1918. Range plants poisonous to sheep and cattle in Nevada. (Spanish translation by B. F. Schapelle.) Nevada Agr. Exp. Sta. Bul. 95:1-51.

47 Francis, C. K.

1915. The poisoning of livestock while feeding on plants of the sorghum group. Oklahoma Agr. Exp. Sta. Cir. 38:1-4.

48 FYLES, F.

1920. Principal poisonous plants of Canada. Canada Dept. Agr. Exp. Farms Bul. 2nd ser. 39:1-112.

49 GaIL, F. W., and A. R. Hahner.

1916. Some poisonous plants of Idaho, and some suggested remedies. Idaho Agr. Exp. Sta. Bul. 86:1-16.

50 Garman, H.

1914. Some Kentucky weeds and poisonous plants. Kentucky Agr. Exp. Sta. Bul. 183:253-339.

51 Gates, F. C.

1930. Principal poisonous plants in Kansas. Kansas Agr. Exp. Sta. Tech. Bul. 25:1-67.

52 GLover, G. H.

1906. Larkspur and other poisonous plants. Colorado Agr. Exp. Sta. Bul. 113:1-24.

53 Glover, G. H., and W. W. RobBins.

1915. Colorado plants injurious to livestock. Colorado Agr. Exp. Sta. Bul. 211:1-71.

54 Gray, Asa.

1897. Synoptical flora of North America. 2:1-392. (See specifically p. 93.) Ivison, Blakeman, Taylor \& Co., New York City.

55 GreENe, E. L.

1889. Vegetative characters of the species of Cicuta. Pittonia Vol. 2. p. 1-11.

56 Greene, E. L.

1894. Manual of the botany of the region of San Francisco Bay. 328 p. (See specifically p. 241.) Cuberey \& Co., San Francisco.

57 HALL, H. M.

1907. Compositae of southern California. Univ. California Pubs., Bot. 3:1-302.

58 Hall, H. M., and F. E. Clements.

1923. The phylogenetic method in taxonomy. The North American species of Artemisia, Chrysothamnus, and Atriplex. Carnegie Inst. Wash. Pub. 326: $1-355$. 
59 HaLl, H. M., and C. C. HaLl.

1912. A Yosemite flora. 282 p. (See specifically p. 189-90.) Paul Elder \& Co., San Francisco.

60 HALL, H. M., and H. S. YATES.

1915. Stock poisoning plants of California. California Agr. Exp. Sta. Bul. 249:217-47.

61 Halsted, B. D.

1899. The poisonous plants of New Jersey. New Jersey Agr. Exp. Sta. Bul. 135:1-28.

62 Haring, C. M.

1917. Precautions against poisoning by Johnson grass and other sorghums. California Agr. Exp. Sta. unnumbered leaflet. 4 p.

63 Hexl, F. W., S. K. Loy, H. G. Knight, and O. L. Prien.

1912. Chemical examination of death camas. Wyoming Agr. Exp. Sta. Bul. 94:1-31.

64 HiтcHсоск, A. S.

1935. Manual of the grasses of the United States. U. S. Dept. Agr. Misc. Pub. 200:1-1040.

65 HowelL, T.

1903. A flora of northwest America. Vol. 1. Phanerogamae. 792 p. (See specifically p. 441.) Published by the author, Portland, Oregon.

66 JePson, W. L.

1911. A flora of western middle California. 515 p. (See specifically p. 323.) Cunningham, Curtiss \& Welch, San Francisco.

67 JePson, W. L.

1922. A flora of California. Pt. VI. p. 193-336. Illus. (See specifically p. 263-6.) Assoc. Students Store, University of California, Berkeley, California.

68 JePSON, W. L.

1923. A revision of California Umbelliferae. Madroño. 1(8):133-46. California Botanical Society, Berkeley.

69 JEPSON, W. L.

1925. A manual of the flowering plants of California. 1238 p. Illus. Assoc. Students Store, University of California, Berkeley, California.

70 KELLOGG, A

1875. California and Colorado "loco" poisons. California Acad. Sci. Proc. 6:3-4. 71 Marsh, C. D.

1909. The loco-weed disease. U. S. Dept. Agr. Farmers' Bul. 380:1-16.

72 Marsh, C. D.

1909. The loco-weed disease of the plains. U. S. Dept. Agr. Bur. Anim. Indus. Bul. 112:1-130.

73 Marsh, C. D.

1912. A field study on the relation of barium to the loco-weed disease. U. S. Dept. Agr. Bur. Plant Indus. Bul. 246(Pt. 1):1-37. 
74 MARSh, C. D.

1914. Menziesia, a new stock-poisoning plant of the northwestern states. U. S. Dept. Agr. Bur. Plant Indus. Preliminary notice. 3 p.

75 Marsh, C. D.

1916. The cause of the "spewing sickness" of sheep. U. S. Dept. Agr. Bur. Anim. Indus. Preliminary notice. 4 p.

76 MARSh, C. D.

1916. Prevention of losses of livestock from poisonous plants. U. S. Dept. Agr. Farmers' Bul. 720:1-10.

77 Marsh, C. D.

1919. The loco-weed disease. U. S. Dept. Agr. Farmers' Bul. 1054:1-19.

78 MarSH, C. D.

1929. Stock-poisoning plants of the range. U. S. Dept. Agr. Dept. Bul. 1245:1-75.

79 Marsh, C. D., and A. B. Clawson.

1908. Results of loco-weed investigatious in the field. U. S. Dept. Agr. Bur. Plant Indus. Bul. 121(Pt. III) :37-8.

80 Marsh, C. D., and A. B. Clawson.

1921. The Mexican whorled milkweed (Asclepias mexicana) as a poisonous plant. U. S. Dept. Agr. Dept. Bul. 969:1-16.

81 Marsh, C. D., and A. B. Clawson.

1921. Poisonous properties of the whorled milkweeds, Asclepias pumila and A. verticillata var. geyeri. U. S. Dept. Agr. Dept. Bul. 942:1-14.

82 Marsh, C. D., and A. B. Clawson.

1922. The death camas species, Zygadenus paniculatus and $Z$. elegans, as poisonous plants. U. S. Dept. Agr. Dept. Bul. 1012:1-25.

83 Marsh, C. D., and A. B. Clawson.

1922. The stock-poisoning death eamas. U. S. Dept. Agr. Farmers' Bul. 1273:1-12.

84 Marsh, C. D., and A. B. Clawson.

1923. Woolly-pod milkweed, a dangerous stock-poisoning plant. U. S. Dept. Agr. Dept. Cir. 272:1-4.

85 MarSh, C. D., and A. B. Clawson.

1924. The meadow death camas (Zygadenus venenosus) as a poisonous plant. U. S. Dept. Agr. Dept. Bul. 1240:1-14.

86 Marsh, C. D., and A. B. Clawson.

1924. The woolly'pod milkweed (Asclepias eriocarpa) as a poisonous plant. U. S. Dept. Agr. Dept. Bul. 1212:1-14.

87 Marsh, C. D., and A. B. Clawson.

1929. Sleepy grass (Stipa vaseyi) as a stock-poisoning plant. U. S. Dept. Agr. Tech. Bul. 114:1-20.

88 Marsh, C. D., and A. B. Clawson.

1930. Toxic effect of St. Johnswort (Hypericum perforatum) on cattle and sheep. U. S. Dept. Agr. Tech. Bul. 202:1-24. 
89 Marsh, C. D., A. B. Clawson, and J. F. Couch.

1923. Greasewood as a poisonous plant. U. S. Dept. Agr. Dept. Cir. 279:1-4.

90 Marsh, C. D., A. B. Clawson, J. F. Couch, and W. W. Eggleston.

1920. The whorled milkweed (Asclepias galioides) as a poisonous plant. U. S. Dept. Agr. Dept. Bul. 800:1-40.

91 Marsh, C. D., A. B. Clawson, J. F. Couch, and H. Marsh.

1921. Western sneeze-weed (Helenium hoopesii) as a poisonous plant. U. S. Dept. Agr. Dept. Bul. 947:1-46.

92 Marsh, C. D., A. B. Clawson, and H. Marsh.

1914. Cicuta, or water hemlock. U. S. Dept. Agr. Dept. Bul. 69:1-27.

93 Marsh, C. D., A. B. Clawson, and H. Marsh.

1915. Zygadenus, or death eamas. U. S. Dept. Agr. Dept. Bul. 125:1-46.

94 Marsh, C. D., A. B. Clawson, and H. Marsh.

1916. Larkspur poisoning of live stock. U. S. Dept. Agr. Dept. Bul. 365:1-91.

95 Marsh, C. D., A. B. Clawson, and H. Marsh.

1916. Lupines as poisonous plants. U. S. Dept. Agr. Dept. Bul. 405:1-45.

96 Marsh, C. D., A. B. Clawson, and H. Marsh.

1917. Cicuta (water hemlock) as a poisonous plant. U. S. Dept. Agr. Bur. Anim. Indus. Leaflet A-15:1-4.

97 Marsh, C. D., A. B. Clawson, and H. Marsh.

1918. Larkspur or “poison weed.” U. S. Dept. Agr. Farmers' Bul. 988:1-15.

98 Marsh, C. D., A. B. Clawson, and G. C. Roz.

1927. Wild tobaceos (Nicotiana trigonophylla Dunal and Nicotiana attenuata

Torrey) as stock-poisoning plants. U. S. Dept. Agr. Tech. Bul. 22:1-23.

99 Marsh, C. D., A. B. Clawson, and G. C. Roe.

1928. Four species of range plants not poisonous to livestock. U. S. Dept. Agr. Tech. Bul. 93:1-10.

100 Marsh, C. D., A. B. Clawson, and G. C. Roe.

1929. Arrow grass (Triglochin maritima) as a stock-poisoning plant. U. S. Dept. Agr. Tech. Bul. 113:1-15.

101 Marsh, C. D., and G. C. RoE.

1920. Sweet-clover seed screenings not injurious to sheep. U. S. Dept. Agr. Dept. Cir. 87:1-7.

102 Marsh, C. D., G. C. Roe, and A. B. Clawson.

1923. Livestock poisoning by cocklebur. U. S. Dept. Agr. Dept. Cir. 283:1-4.

103 Marsh, C. D., G. C. Roe, and A. B. Clawson.

1924. Cockleburs (species of Xanthium) as poisonous plants. U. S. Dept. Agr.

Dept. Bul. 1274:1-24.

104 Mathews, Frank P.

1932. Locoism in domestic animals. Texas Agr. Exp. Sta. Bul. 456:1-28. 
105 MAY, W. L.

1920. Whorled milkweed, the worst stock-poisoning plant in Colorado. Colorado Agr. Exp. Sta. Bul. 255:1-40.

106 MoRris, H. E., and H. WELCH.

1927. Plants poisonous to livestock in Montana. Montana Agr. Exp. Sta. Cir. 134:1-28.

107 NELSON, S. B.

1906. Feeding wild plants to sheep. Washington Agr. Exp. Sta. Bul. 73:1-64. 108 NutTali, T.

1847. Descriptions of plants collected by William Gambel, M.D., in the Rocky Mountains and upper California. Acad. Nat. Sci. Phila. Jour. ser. 2, 1:149-90. (See specifically p. 180.) 3 plates.

109 ORR, J. B.

1929. Minerals in pastures. 150 p. H. K. Lewis \& Co., Ltd., London.

110 PammeL, L. H.

1911. A manual of poisonous plants. 977 p. (See specifically p. 632.) The Toreh Press, Cedar Rapids, Iowa.

111 Sampson, A. W.

1924. Native American forage plants. 435 p. John Wiley \& Sons, New York City.

112 Sampson, A. W., and K. W. PARKer.

1930. St. Johnswort on range lands of California. California Agr. Exp. Sta. Bul. 503:1-48.

113 SMilei, F. J., et al.

1922. Weeds of California and methods of control. California State Dept. Agr. Mo. Bul. 11(2-3):i-xxii, 73-360.

114 ViNALL, H. M.

1921. A study of the literature concerning poisoning of cattle by the prussic acid in sorghum, Sudan grass, and Johnson grass. Jour. Amer. Soc. Agron. 13(6-7):267-80.

115 WATSON, SERENO.

1880. California Geological Survey (botany of California) 2:1-559. (See specifically p. 184, 463.) John Wilson \& Son, Univ. Press, Cambridge, Mass.

116 Wooton, E. O., and P. C. StandLey.

1915. Flora of New Mexico. Contrib. U. S. Natl. Herbarium 19:1-794. (See specifically p. 511.) 